\title{
FLUX OF ENERGY AND ESSENTIAL ELEMENTS THROUGH THE CONTINENTAL SHELF ECOSYSTEM
}

\author{
PROGRESS REPORT \\ $\checkmark$

\section{MASTER}

L. R. Pomeroy
Institute of Ecology, University of Georgia

Athens, Georgia 30602

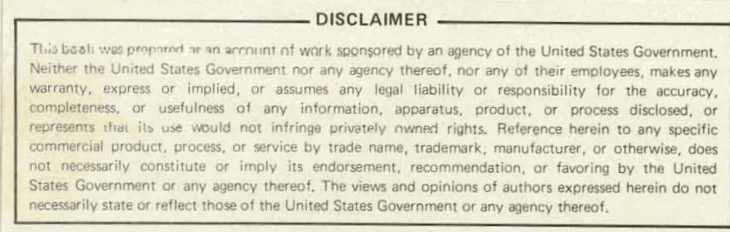

May 31, 1980 to May 31, 1981

Report Date: February 1, 1981

Propared for the U. S. Department of Energy under Contract DE-AS09-76EV00639 


\section{DISCLAIMER}

This report was prepared as an account of work sponsored by an agency of the United States Government. Neither the United States Government nor any agency Thereof, nor any of their employees, makes any warranty, express or implied, or assumes any legal liability or responsibility for the accuracy, completeness, or usefulness of any information, apparatus, product, or process disclosed, or represents that its use would not infringe privately owned rights. Reference herein to any specific commercial product, process, or service by trade name, trademark, manufacturer, or otherwise does not necessarily constitute or imply its endorsement, recommendation, or favoring by the United States Government or any agency thereof. The views and opinions of authors expressed herein do not necessarily state or reflect those of the United States Government or any agency thereof. 


\section{DISCLAIMER}

Portions of this document may be illegible in electronic image products. Images are produced from the best available original document. 
This report was prepared as an account of work sponsored by the United States Government. Neither the United States nor the United States Energy Research and Development Administration, nor any of their employees, nor any of their contractors, subcontractors, or their employees, make any warranty, express or implied, or assume any legal liability or responsibility for the accuracy, completeness, or usefulness of any information, apparatus, product or process disclosed, or represents that its use would not infringe privatelyowned rights. 
I. Scope of the Research of the Past Three Years 1

Abstract $\quad 1$

1. Cooperative studies of Gulf Stream intrusions 2

1.1 The research program . . 2

1.2 The physical regime 3

1.3 The planktonic comnunity $\quad \cdots * 4$

1.4 Analysis of microbiological methods 6

1.5 GABEX I 11

1.6 EASTWARD Cruise E3B-79 16

1.7 R/V GILLIS Cruise, Apri1 19-May2, $1979 \quad 20$

$1.8 \mathrm{R} / \mathrm{V}$ ISELIN Cruise, April 24-25, $1978 \quad 25$

1.9 R/V ISELIN Cruise, August 3-10, 1978

2. Coastal fronts $\quad$.. 27

2.1 Cooperative front study, May 9-12, $1978 \quad 28$

2.2 FRNFLX I, November 6-9, 1979

3. Microbial populations and the detritus food web 37

3.1 Methods of microscopy 38

3.2 Utilization of dissolved substrates by bacteria in Gulf Stream intrusions 39

3.3 Interactions of populations of free bacteria, attached bacteria, and aggregates $\quad 40$

3.4. Production of fecal aggregates. 42

3.5 A simulation model of the shelf ecosystem 42

4. The effect of copper on photosynthesis of marine phytoplankton 69

Literature cited . . 70

5. Publications and reports resulting from this contract $74^{\text {. }}$ Appendix: reprints and preprints of publications

Jacoboen, T. R. 1978. A quantitative method for the separation of $a$ and $b$ from phytoplankton by high pressure liquid chromatography.

Pomeroy, L. R. 1979. Secondary production mechanisms of continental shelf communities.

Pomeroy, L. R. and D. Deibel 1980. Aggregation of organic matter by pelagic tunicates. 
Pomeroy, L. R. 1980. Microbial roles in aquatic food webs.

Campbell, W. B., T. R. Jacobsen, and L. R. Pomeroy 1979. Heterotrophicphotoautotrophic index: a qualitative parameter of microbial interactions applied to a Gulf Stream intrusion.

Hodson, R. E., A. E. Maccubbin, and L. R. Pomeroy (in press) Dissolved adenosine triphosphate and its utilization by free-living and attached bacterioplankton.

Jacobsen, T. R. (in press). Comparison of chlorophyll a measurements by fluorometric, spectrophotometric, and high pressure liquid chromatographic methods in aquatic environments.

Berman, T. (ms.) Phosphorus uptake by microplankton in estuarine and coastal shelf water near Sapelo.Island, Ga., U. S, A.

Berman, T., R. B. Hanson, and W. J. Wiebe (ms.). Effects of organic substrate addition on size partitioning and respiration of 'single' versus clumped or 'attached' marine bacteria.

Wood, A. M. and D. W. Evans (ms.) Copper chelating capacity in the Sargasso Sea and on the continental shelf of the southeastern United States. 
I. Scope of the Research of the Past Three Years

Abstract

There are three distinct but not mutually exclusive areas of research in this contract, studies of intrusions of the west wall of the Gulf Stream onto the outer continental shelf, studies of the flux of materials across near -shore density fronts, and advances in our understanding of the planktonic. food web of the continental shelf. Our studies of frontal events on the outer and inner continental shelf involve distinctive physical and chemical regimes and have proven to require distinctive biological approaches. The studies of the food web run through our work on both of the frontal regimes, but certain aspects have become subjects in their own right. We have developed a simulation model of the flux of energy through the continental shelf food web which we believe to be more realistic than previous ones of its type. It represents realistically both details of the energy transfers within the plankton community and the termanal production of fishes. In a serendipitous, almost accidental way, we discovered that the fecal ribbons of pelagic tunicates break up into flocculent material visually and chemically identical with the flocculent organic aggregates present in sea water. Subsequent experimental work with tunicate fecal matter indicates that some of the naturally occurring aggregates are indeed fecal. This makes it possible to understand and quantify for the first time the production and fate of that population of seston. We have examined several of the many roles of dissolved organic compounds in sea water which originate either from release by phytoplankton, digestive processes or metabolites of zooplankton, or extracellular digestion of microorganisms. We have found that the uptake of dissolved materials, in this instance represented by dissolved adenosine triphosphate, is nearly proportional to bactérial biomass, and that free-living minibacteria and large bacteria attached to particles are equally active in scavenging that material from the water. Many naturally occurring dissolved organic compounds are chelators of heavy metals, and it has been realized for some time that much of the total metal content of sea water is in a chelated form. This would have a significant effect on the toxicity of metals to plankton. Methods have been developed under this contract to measure both the chelating capacity of naturally occurring organic materials and the copper concentration in the water. Using these methods in 
conjunction with the Schindler modification of the ${ }^{14} \mathrm{C}$ method of measuring photosynthesis, it has been possible to characterize the effects, both toxic and stimulatory, of copper on photosynthesis of naturally occurring phytoplankton populations.

Our understanding of biological, as well as physical and chemical, events on the outer continental shelf is now on a firm basis. Thanks to our knowledge of the physical forcing of the regime by the west wall of the Gulf Stream, it is possible to characterize in considerable detail the course of biological events associated with meanders of the Gulf Stream. Although there are a number of variations on the theme, the general course of events is a predictable one. We are now in a position to explain the limits to biological productivity of the outer continental shelf of the southeastern U.S. and the reasons why that biological production moves through the food web in the characteristic way that it does.

\section{Cooperative Studies of Gulf Stream Intrusions}

\subsection{The Research Program}

During the past three years we have participated in five cooperative studies of intrusions of nutrient-rich water from the cold wall of the Gulf Stream over the outer continental shelf off Georgia and northern Florida. On four of these occasions the scientific party included physical oceanographic contractors as well as other biological DOE contractors and ourselves.. This cooperative work between physical and biological oceanographers has contributed significantly to the success of the biological research program. We have been able to find the physical events we are seeking with minimal loss of valuable ship time. The use of infrared imagery from weather satellites, processed and relayed from Miami (RSMAS), was particularly helpful not only in determining the position of the Gulf Stream but in finding intrusions from the west wall of it, so the ship could be positioned in advance of a northward -moving eddy. This permitted us on several occasions to obtain daily observations of the succession of planktonic populations as an intrusion event arrived and was subsequently drawn back over the shelf break. We have, of course, learned the basic pattern of events from the physical oceanographers, and on EASTWARD cruise E1B-79 we were readily able to locate and follow an intrusion off Jacksonville, Florida without the participation of physical oceanographers. 


\subsection{The Physical Regime}

While the detailed information on physical processes on the outer continental shelf of the southeast will be found in the reports to DOE by Atkinson; Lee, and Peitrafesa, we present here an outline of the general features of the system which are important to an understanding of biological processes on the outer shelf.

Meanders of the Gulf Stream appear to be perturbations of the Rossby wave type generated downstream of topographic features, such as Cape Canaveral or the so-called Charleston bump (Atkinson 1977; Blanton et al. 1979; Lee and Brooks 1979; Pietrafesa et al inpress). Because of this relationship to fixed physical features, the intensity and frequency of intrusions varies along the coast, with a region of high frequency of intrusion events off St. Augustine and Jacksonville, Florida, and in Onslow Bay, in North Carolina. The Georgia shelf is a region of comparatively low activity, although many events take the form of moving eddies which sweep up the shelf break through both Florida and Georgia. The period of Gulf Stream meanders is about 5 days, and complete cycles of intrusion and relaxation occur in the active areas at about that rate. South winds during an intrusion may have an Ekman effect, causing the intruded water to remain on the shelf. It is not unusual in summer, when consistent, brisk southerly winds occur, to observe one intrusion move in under a former one, and even a third move in under the others. Cold water stranded on the continental shelf may remain for a week or more as a distinct water body, isolated by density differences from the water above it and around it. Such bodies of nutrient-rich water are the sites of phytoplankton and zooplankton blooms, because they are a persistent source of nutrients (Atkinson et al. 1978). Intrusions which do not strand on the shelf will be drawn back over the shelf break into deep slope water after two or three days, just as a phytoplankton and bacterial bloom is well established.

With the possible exception of Onslow Bay and Raleigh Bay, the impact of intrusions of nutrient-rich water is less than might be expected. This is because those which strand are, except in the North Carolina bays, rare events, and those which do not are swept back out into the Gulf Stream, with most of the productivity going back down into relatively deep water. Nevertheless, intrusions are the major source of new nitrogen for phytoplankton production on the southeastern continental shelf (Dunstan and Atkinson 1977). While frontal intrusions and related frontal processes are widespread (Savidge 
and Foster 1978; Pingree et al. 1979; Floodgate et al. 1981), these take a unique form on the southeastern continental shelf because of the proximity of the west wall of the Gulf Stream to the shelf break. It is curiious that the positive effect on productivity of intrusions of the west wall is nearly nullified by the relaxations which follow closely, before secondary production of plankton larger than bacteria can occur. The northerly and westerly regional wind fields, which predominate except in summer, tend to reenforce the loss of intruded water rather than its retention. This is in contrast to the. typical regime of coastal upwellings in which edge waves interact positively with the regional wind field to induce upwelling of nutrient-rich water to the surface, where it remains, allowing primary and secondary biological production processes to go to completion.

\subsection{The Planktonic Community}

Because of their short generation times, microbial populations respond to even the most transitory intrusions of nutrient-rich water over the contiental shelf. As this water enters the zone of $>1 \%$ of surface solar illumination, a bloom of phytoplankton begins to develop. The initial bloom organisms are small, one of those repeatedly found being Thalassiosira subtilis ( $J$. Yoder, pers. comm.), a $5 \mu \mathrm{m}$ diatom. This is accompained by blooms of bacteria, although these are not usually congruent in space. The greatest bacterial densities are typically above or toward the land with respect to the center of the bloom of phytoplankton. It is not clear what causes this physical separation of the bacterial and phytoplankton blooms but it has also been observed in the Irish Sea by Floodgate et al. (1981). In the case of Gulf Stream intrusions, the blooms of bacteria are not in the intrusion itself but in the old shelf water adjacent to it. There is, of course, some diffusion of water between the intrusion and the old shelf water as a result of the combined action of internal waves running on the top of the intruded water, tidal currents on the continental shelf, and eddy diffusion.

Bacteria of the shelf waters are composed of two morphologically distinct groups, the large $(>1 \mu \mathrm{m})$ bacteria usually associated with particulate organic material, and the minibacteria $(<0.5 \mu \mathrm{m})$, originally described by Watson et al. (1977), which are free in the water. The latter may be seen doubling but never form colonies in the water. The former often form colonies on seston particles. There are $10^{5}$ minibacteria/ml in continental shelf water. The number may reach $10^{6} / \mathrm{ml}$ in blooms associated with intrusions. Minibacteria 
are more abundant than large, attached bacteria by about two orders of magitude, but because of their small size they constitute only about half of the bacterial biomass, and probably they are responsible for half of the production of new bacterial biomass (Hodson et al. in press).

What is surprising is that free and attached bacteria vary in numbers together, and in fact both vary synchronously with populations of flocculent organic seston. The greatest population densities of chroococcoid cyanobacteria (Johnson and Sieburth 1979; Waterbury et al. 1979) also are associated with dense concentrations of flocculent organic matter. The flocculent organic matter is frequently associated with intrusions but is in the water above them as well as in the intrusions proper. We have associated some of this seston with feces of pelagic tunicates, which are also abundant at the interfaces of intrusions with shelf water and above them. It is reasonable to suppose that the pelagic tunicates are responding to the bloom of bacteria, as well as phytoplankton, by feeding actively and producing feces. According to King et al. (1980), pelagic tunicates can be expected to derive significant nutrition from bacteria but not to greatly influence the total numbers of bacteria in the water. However, the most dense populations of tunicates encountered on the outer shelf may even depress bacterial numbers (Deibel 1980). While the activity of pelagic tunicates may explain the increase in both the numbers of flocs and of bacteria, other mechanisms of production of flocculent aggregates are known (Johnson and Cooke 1980; Kranck and Milligan 1980), it is not clear how they operate in the regime of the outer continental shelf to produce distinctive, localized populations of flocculent seston. Whatever the mechanism, there is an increase in populations of bacteria and flocculent aggregates associated with intrusions of nutrient-rich Gulf Stream water. Secondary production in these water bodies involves the production of bacterial biomass and probably the production of organisms which consume bacteria, such as ciliates and pelagic tunicates. The role of the ciliates in consuming bacteria in fecal flocs has been described by us elsewhere in this report (Pomeroy and Deibel 1980, included as a part of this report).

The picture which emerges from our experience with about ten intrusions. over the past six years is one of a rapid increase in primary production during the first 24 hours with a phytoplankton bloom localized in the intrusion or at the interface between the intrusion and the shelf water above it. 
Concurrent with this is a bloom of bacteria in the water above or inshore of the intrusion. Where these events persist for several days, dense populations of pelagic tunicates develop in the water in the vicinity of the thermocline between intrusion and shelf water. These are often associated with an increase in flocculent seston in the water. They are extremely dynamic events in both space and time. Because water is usually moving laterally along the shelf as well as in and out over the shelf break, it is not possible to follow events in exactly the same body of water through time. Doing so would require threedimensional mapping on a local scale, and would require more personnel and ship time than we have at our disposal.

\subsection{Analysis of Microbilogical Methods}

On several cruises over the past three years we have done microscopic counts of bacteria as well as the more rapid biochemical analyses which are much less costly in processing time. Because there appears to be no perfect biochemical indicator of bacterial numbers or biomass at this time, we have done a partial correlation analysis of data from three cruises, EASTWARD E3B-79, FRNFLX I (GILIISS and BLUE FIN); and BLUE FIN 10-80. These data cover the entire width of the continental shelf, from the nearshore front to the Gulf Stream (Table 1). While this approach is a relative one, and one which says nothing about causation, it gives some indication of the interpretation which can be placed on the biochemical parameters of microbial abundance that we are using.

Correlation of total bacteria and free bacteria with ATP concentration. was 0.72 , while correlation of total and free bacteria with total adenylates was 0.82 (Table 3 ). Thus, the analysis of total adenylates does offer some improvement over ATP alone, but perhaps not one that is commensurate with the additional costs and processing time involved.

Chlorophyll has a rather high correlation (0.60) with both free and total bacteria, suggesting that although the peak densities of the two populations, phytoplankton and bacteria, appear to be offset in plots of oceanographic sections, bacteria do occur where phytoplankton (as indicated by chlorophyll concentration) are most abundant. This is what one would expect. However, it unfortunately tends to nullify any attemp to seek correlations of chlorophyll with ATP or adenylates, since bacteria and phytoplankton converge in our data 
Table 1. Combined data from cruises E3B-79, FRNFLX I, and BLUE FIN 10-80.

FREEBAC = free bacteria

NO3 = nitrate

ATTBAC = attached bacteria

SAL $\quad=$ salinity

TBAC = total bacteria

CHL-A = chlorophyll a

PC-ATT = per cent of bacteria attached

PHEO-A = pheophytin a

FLOCFEC = fecal-type floc. aggregates

ATP

= extracted ATP

PHYTO = phytoplankton (counted)

NVPHYTO = non-viable phytoplankton

CYANO = chroococcoid cyanobacteria

AXP

= extracted total adenylates

EC = adenylate energy charge

HPINDEX = heterotrophic-photoautotrophic index (AXP/CHL-A)

VARIABLE.

$N$

MEAN

STD DEV

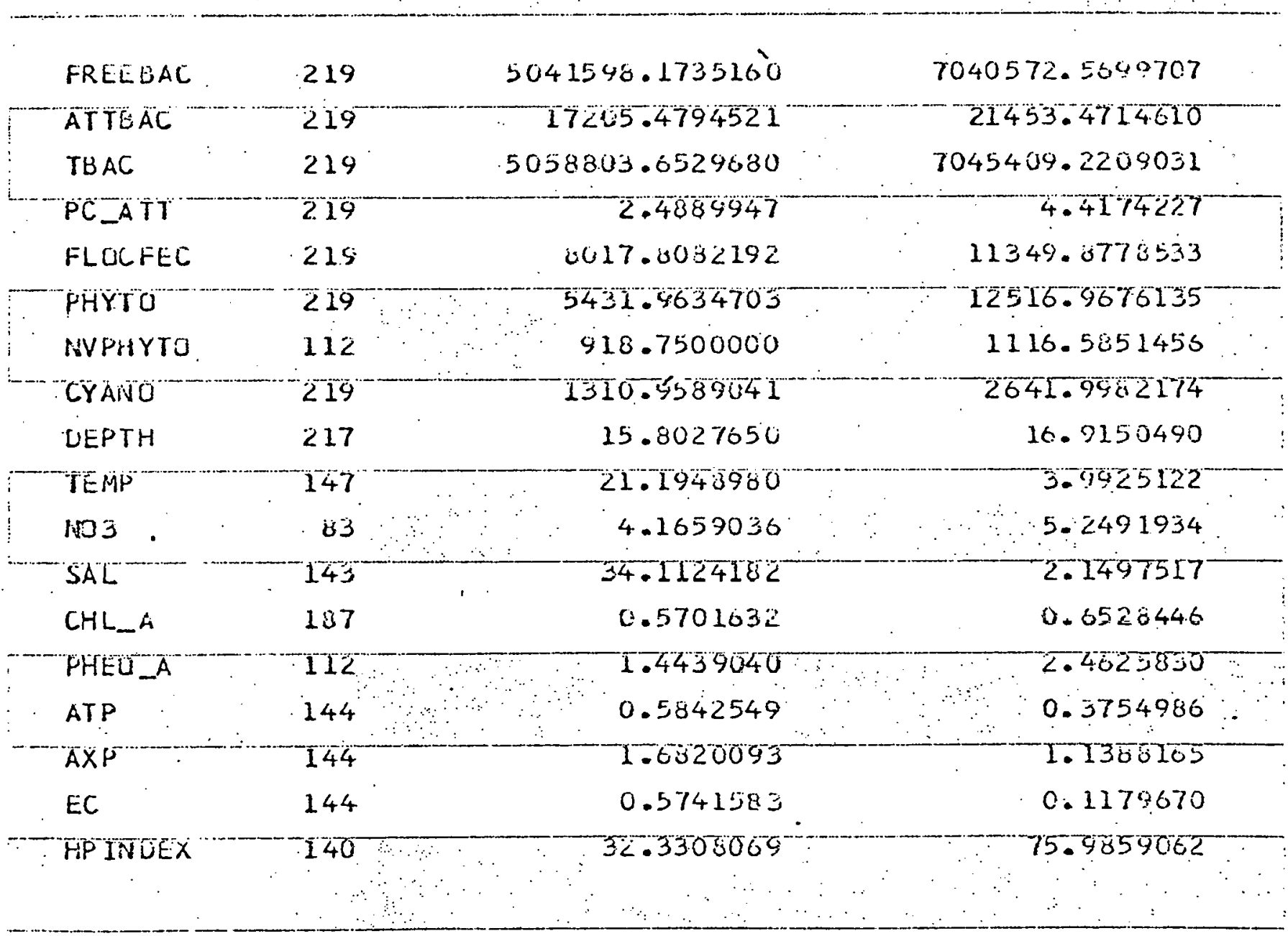


Table 2. Combined data from cruises E3B-79, FRNFLX I, and BLUE FIN 10-80. Pearson correlation coefficients, probability, and number of observations.

Variables are the same as in Table 1 .

-EC

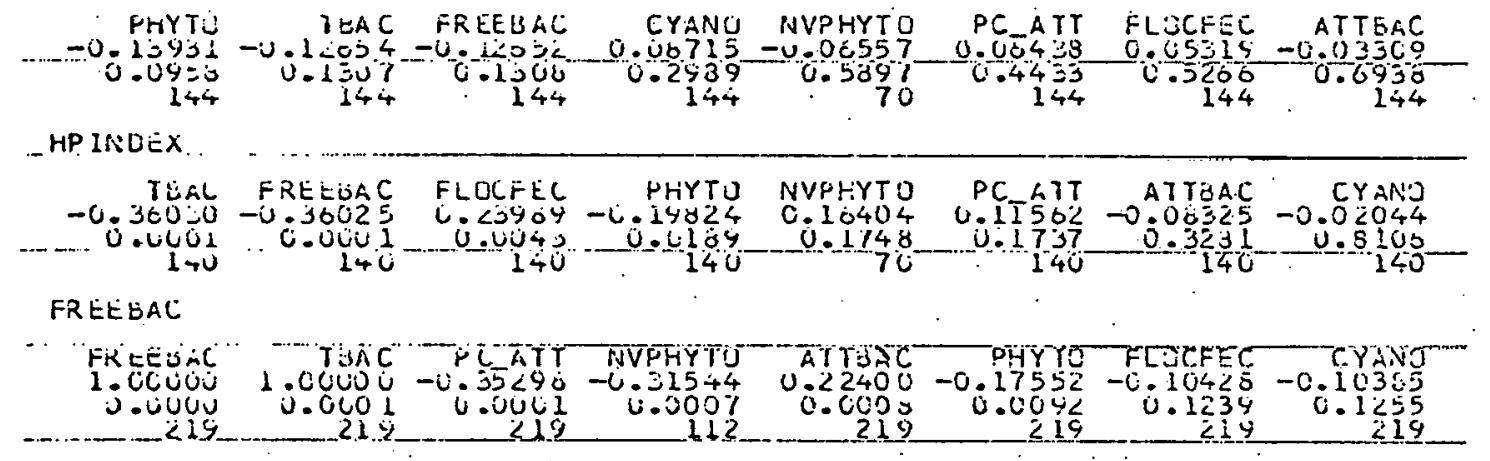

ATTSAC

\begin{tabular}{|c|c|c|c|c|c|c|c|}
\hline 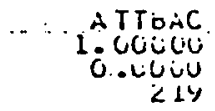 & 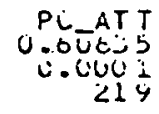 & $\begin{array}{c}T S A C \\
0<0684 \\
0.0007 \\
<1 Y\end{array}$ & $\begin{array}{r}F R E E B A E \\
-2<400 \\
0.4008 \\
219\end{array}$ & $\begin{array}{r}\text { PHYT } \\
0.16354 \\
0.0155 \\
215\end{array}$ & $\begin{array}{r}\text { CYANO } \\
0.0179 \\
0.4459 \\
21 \%\end{array}$ & $\begin{array}{r}\text { FLOCFEC } \\
0.05015 \\
0.460 \\
215\end{array}$ & $\begin{array}{r}\text { NVP YYTO } \\
-0.0 \% \text { OST } \\
0.7403 \\
112\end{array}$ \\
\hline
\end{tabular}

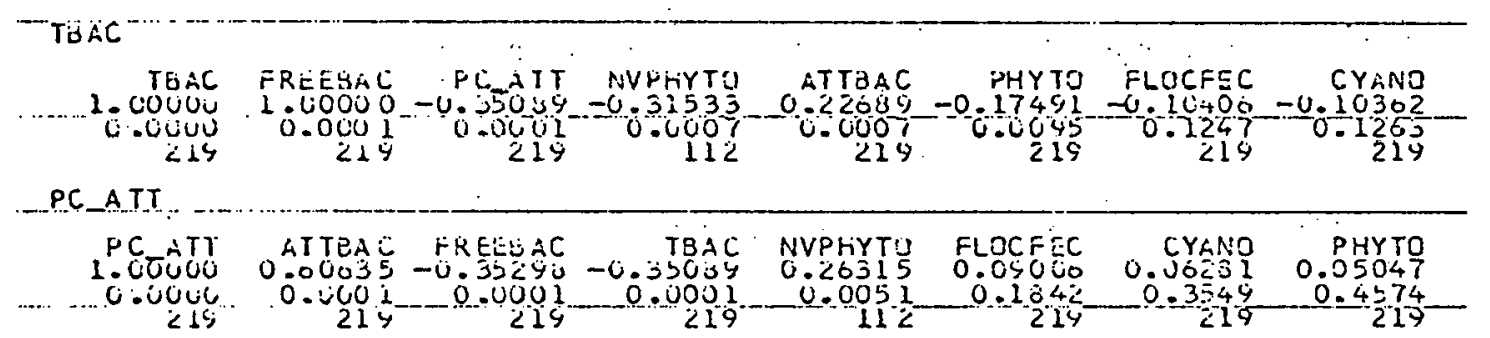

FLOCFEC

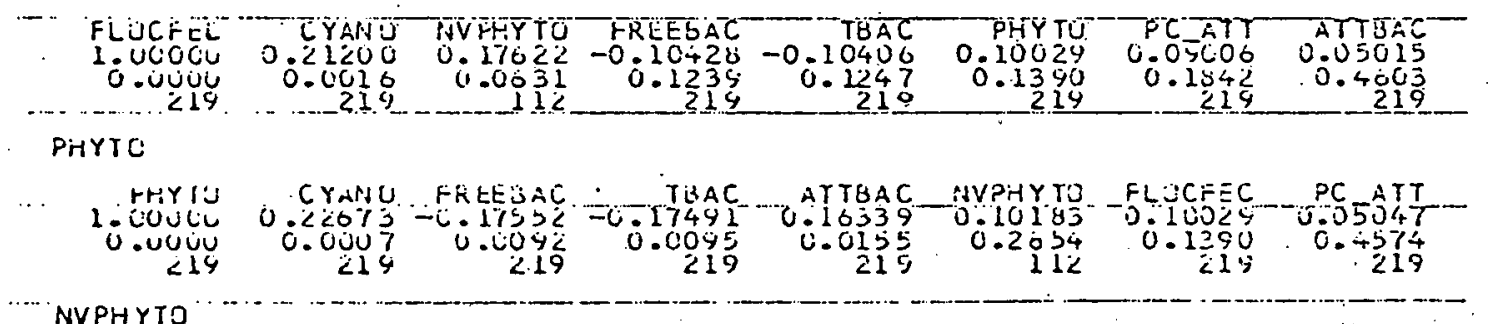$$
\text { - CYANO }
$$

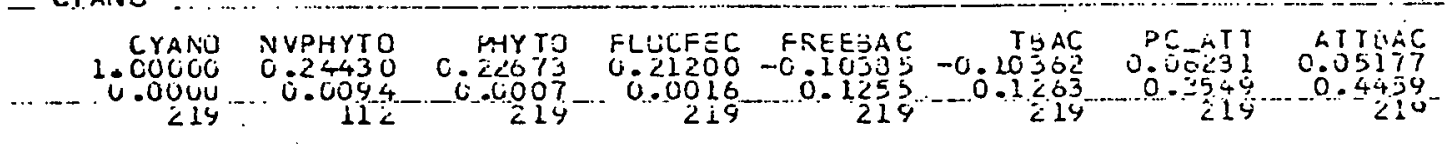


Table 3. Combined data from cruises E3B-79, FRNFLX I, and BLUE FIN 10-80. Spearman correlation coefficlents, probability, and number of observations. Varlables are the same as in Table 1.

CYL_A

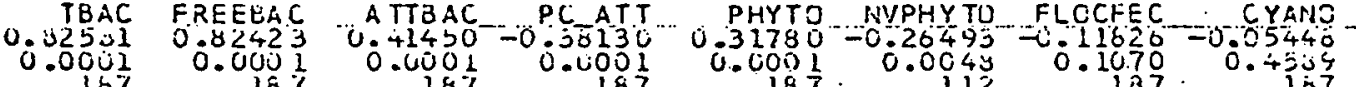

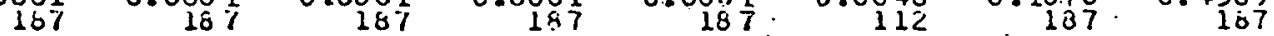

PHEO_A $\cdots \cdots-\cdots+\cdots$

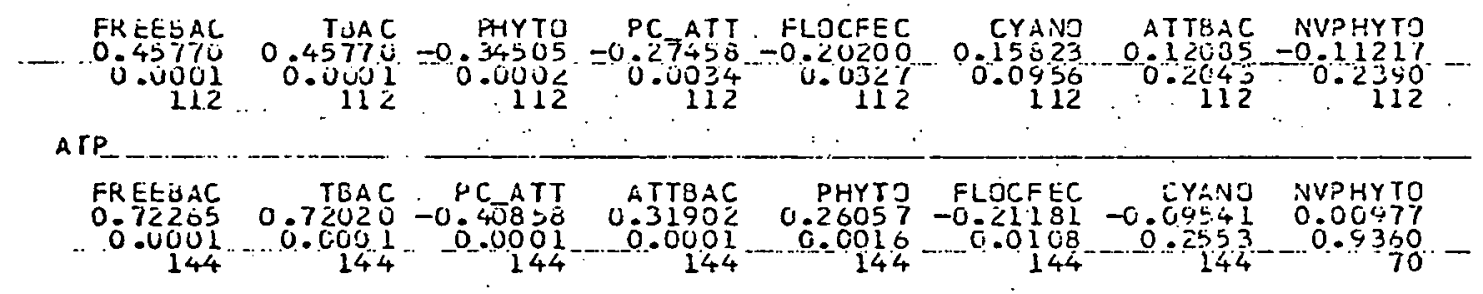

$\operatorname{Axp}$

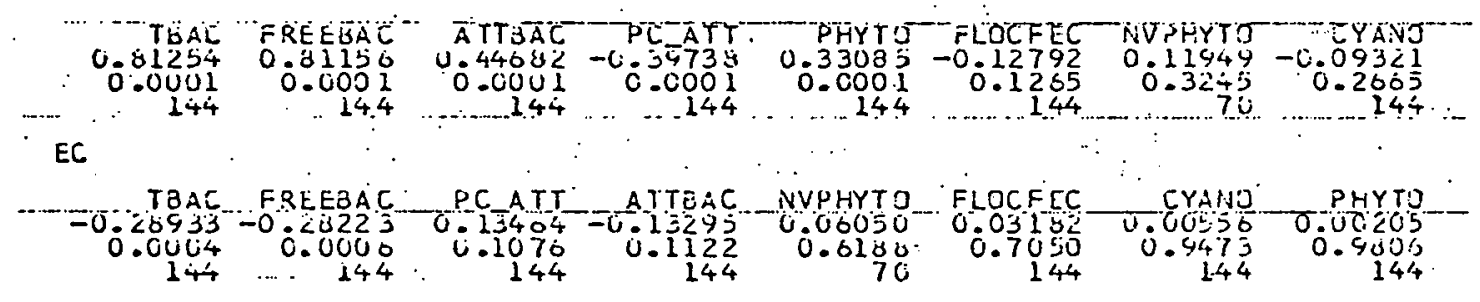

HPIN IEX

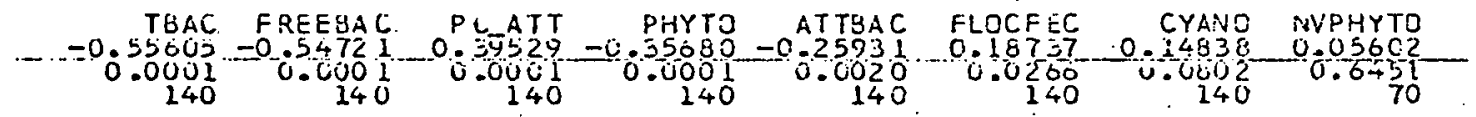

FREEEAC

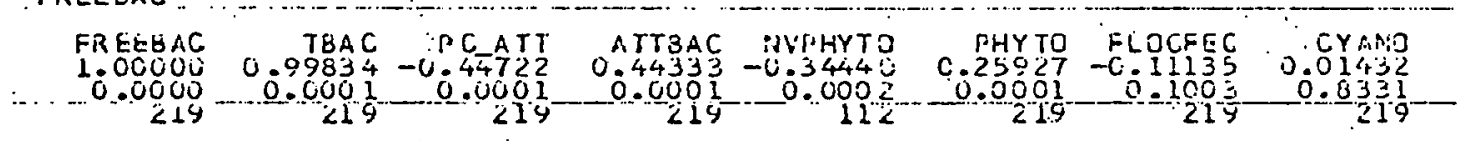

ATTBAC

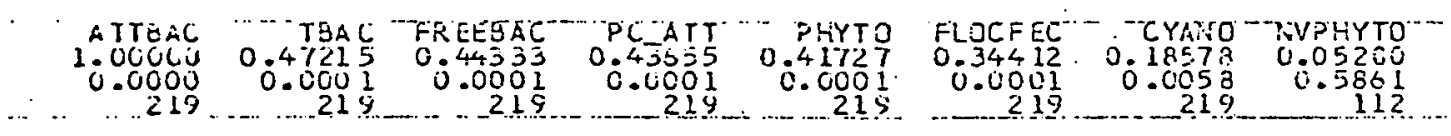

TBAC

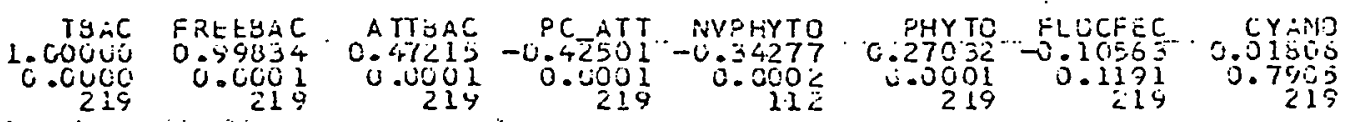


Table 3, continued.

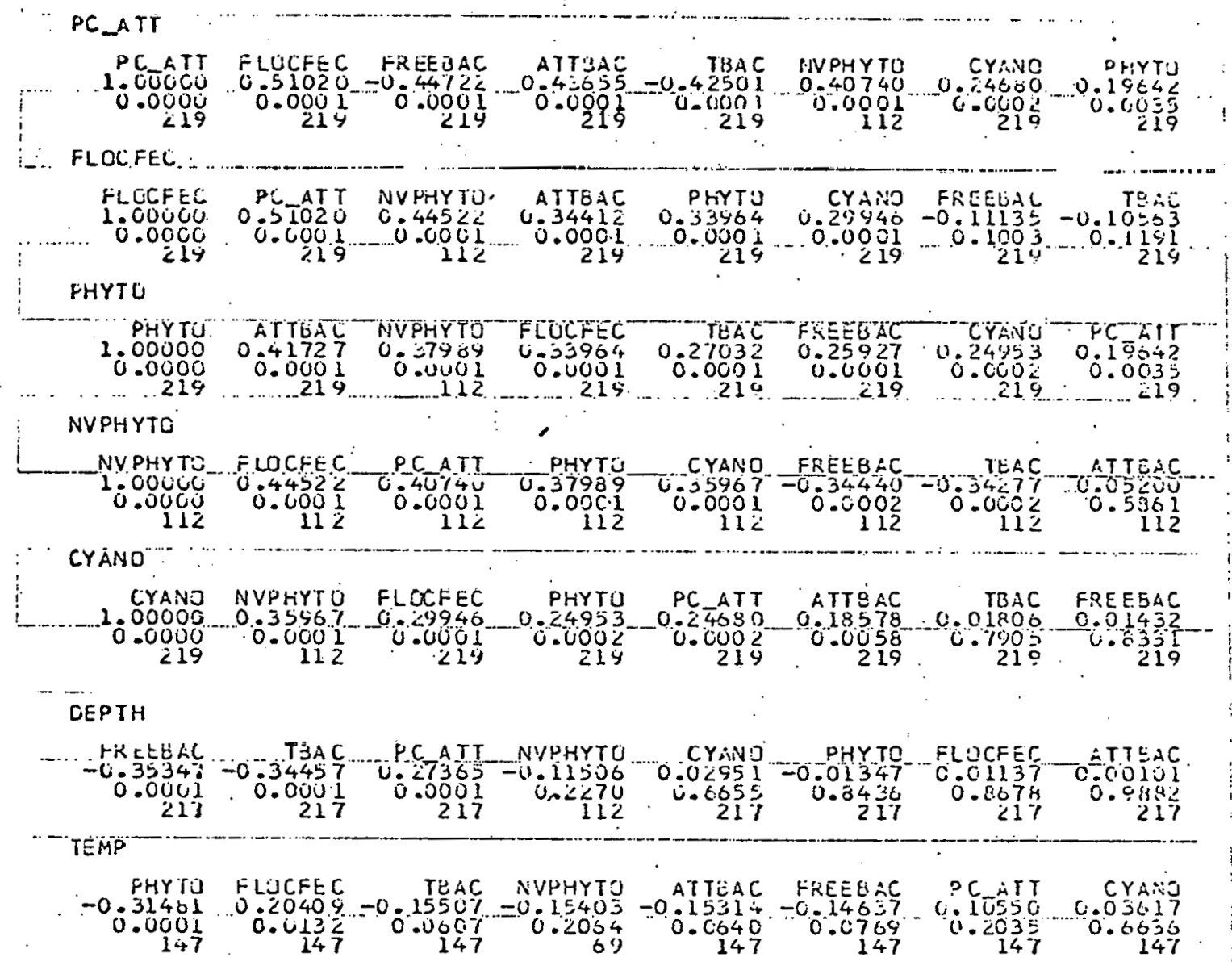
NO 3

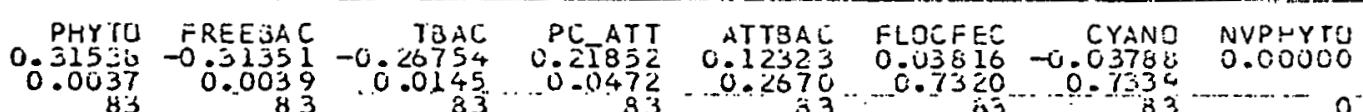

SAL

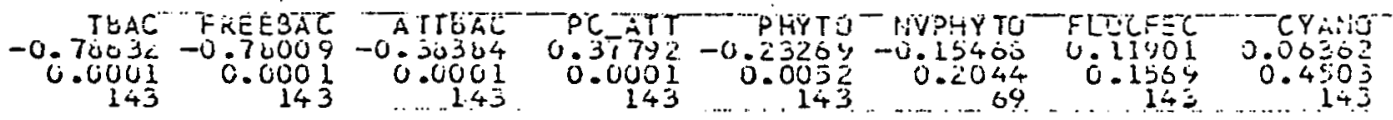


Table 4. Net primary production in simulations of various intrusion and upwelling events used for modeling the detrital food web.
g C m $\mathrm{m}^{-2} \mathrm{yr}^{-1}$
$\mathrm{KCal} \mathrm{m}^{-2} \mathrm{yr}^{-1}$
$\mathrm{KJ} \mathrm{m}^{-2} \mathrm{yr}^{-1}$

$\begin{array}{llccc}4 \text { intrusions, regular } & & 143 & 1630 & 6820 \\ 4 \text { intrusions, regular, yr. } 1 & 143 & 1629 & 6816 \\ & \text { yr } 2 & 149 & 1704 & 7130 \\ & \text { yr } 3 & 150 & 1.706 & 7140 \\ & \text { yr } 4 & 149 & 1697 & 7100 \\ & \text { yr } 5 & 149 & 1694 & 7088 \\ 4 \text { intrusions, stochastic } & 141 & 1607 & 6742 \\ \text { constant upwe11ing } & & 7.61 & 8671 & 36279 \\ \text { Peru upwelling } & & 326 & 3715 & 15544 \\ \text { spring bloom 1 } & & 182 & 2069 & 8657 \\ \text { spring bloom 2 } & & 140 & 1599 & 6690\end{array}$


set. Therefore, we must continue to fall back on the use of the HP index (Campbell et al. 1979) to separate phytoplankton dominance from microbial heterotroph dominance in individual samples. It is also worth noting that the distribution of bacteria counts is highly contagious (variance $>$ mean) while that of ATP and adenylates approaches a Poisson distribution. Therefore, some of the apparent increased precision offered by microscopic counting cannot be realized because of the statistical problems of dealing with a negative binomial distribution.

\subsection{GABEX I}

In April, $1980 \mathrm{R} / \mathrm{V}$ TSFTTN and R/V EASTWARD were uscd concurrently tu study mesoscale events on the outer continental shelf between Cape Canaveral and Savannah, Georgia. This was supported by overflights of remote-sensing aircraft (a NASA U-2 high altitude flight and Coast Guard low-altitude flights) and by deployment of an extensive array of current meters by T.N. Lee. The two-ship plan gave continuous coverage of the Georgia and Florida continental shelf while permitting flexibility to follow intrusion events as they occurred: $R / V$ EASTWARD maintained a regular cruise track, repeatedly sampling along a series of transects from Savannah to $\mathrm{St}$. Augustine. $\mathrm{R} / \mathrm{V}$ ISELIN began by covering the outer portion of the grid out of phase with the EASTWARD, but as the three-week study progressed ISELIN turned to more specialized mapping and intrusion hunting. Our program had three persons on EASTWARD and one on ISELIN. This was the maximum space available to us. One of the inevitable consequences of cooperative studies is the limitation on the size of each of the research teams. As a result, we were unable to sample all transects continuously as we would have liked. We concentrated on the St. Augustine transect, because experience had shown this to be a region of frequent intrusions from the west wall of the Gulf Stream.

April, 1980, proved to be an unusual period of runoff of freshwater from the coast, with $34 \%$ salinity extending far out across the shelf at times. Intrusion activity was weak, without the appearance of prominent eddies, but it was essentially continuous through the period, with some nutrient-rich water on the outer continental shelf much of the time. This is indicated by the presence of lenses of $18^{\circ}$ water at the bottom on the outer continental shelf during most of the period (Figure 1). 

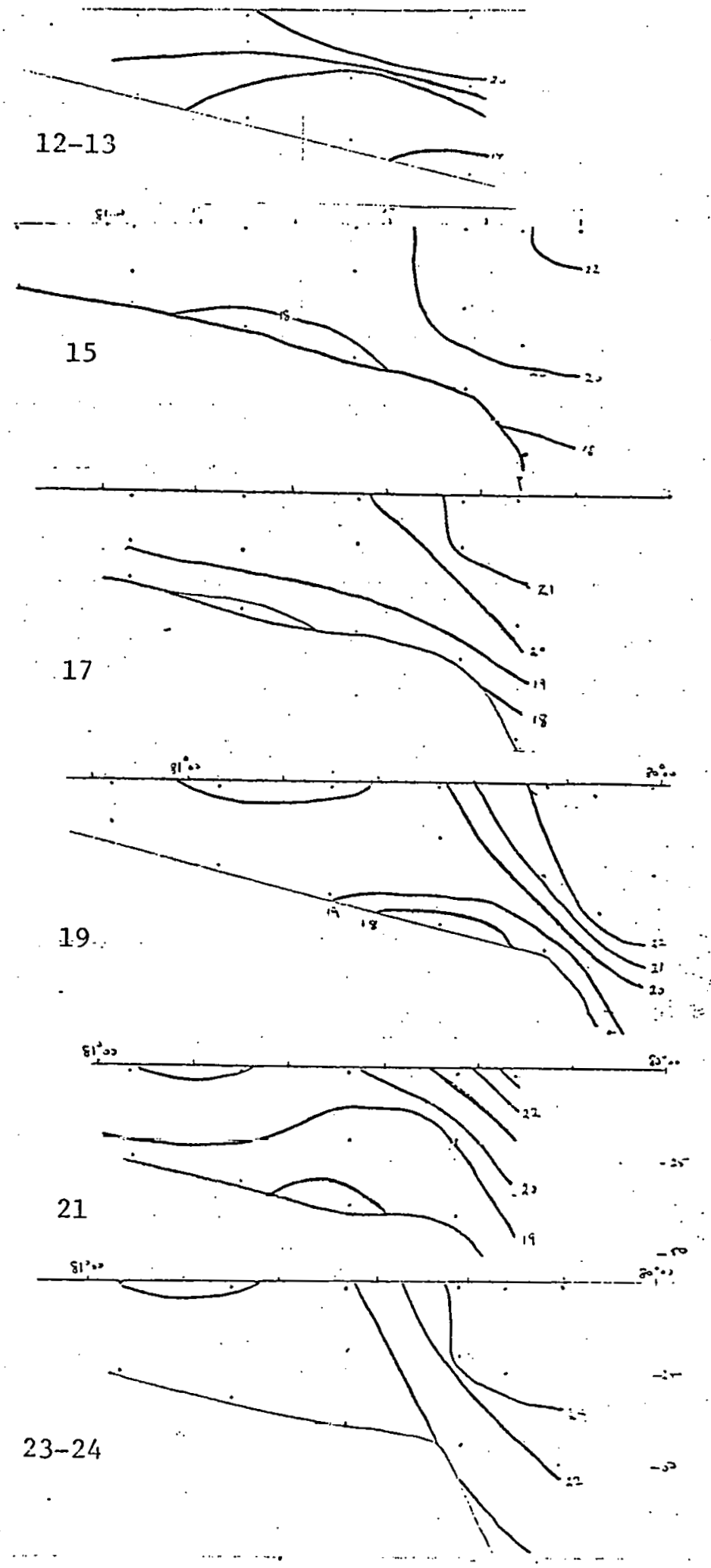

Figure 1. St. Augustine hydrographic section, GABEX I, April 12-24, 1980. Temperature, ${ }^{\circ} \mathrm{C}$, provided by L. P. Atkinson. 

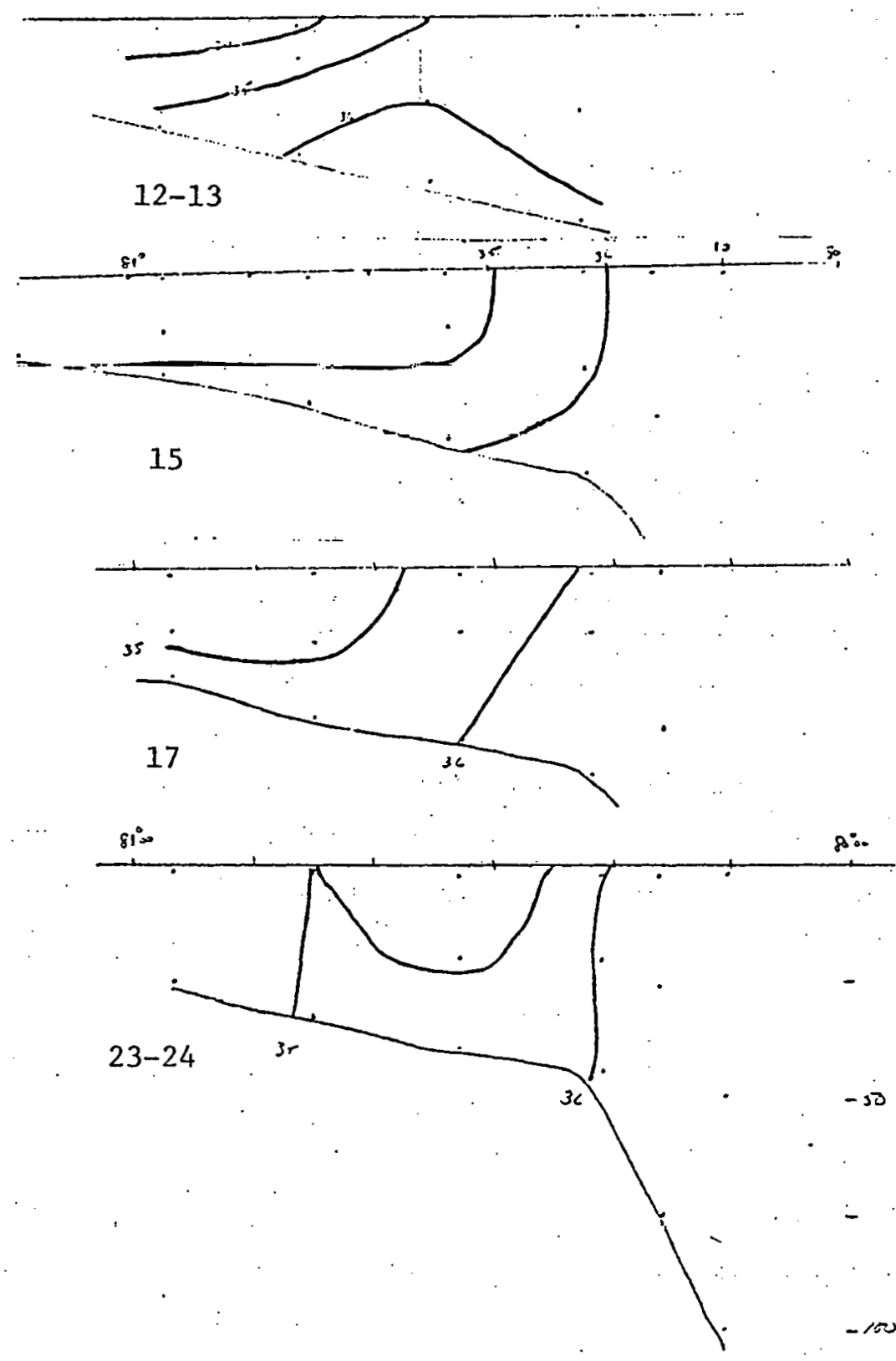

Figure 2. St. Augustine hydrographic section, GABEX I, April 12-24, 1980. Salinity, \%o, provided by L. P. Atkinson. 


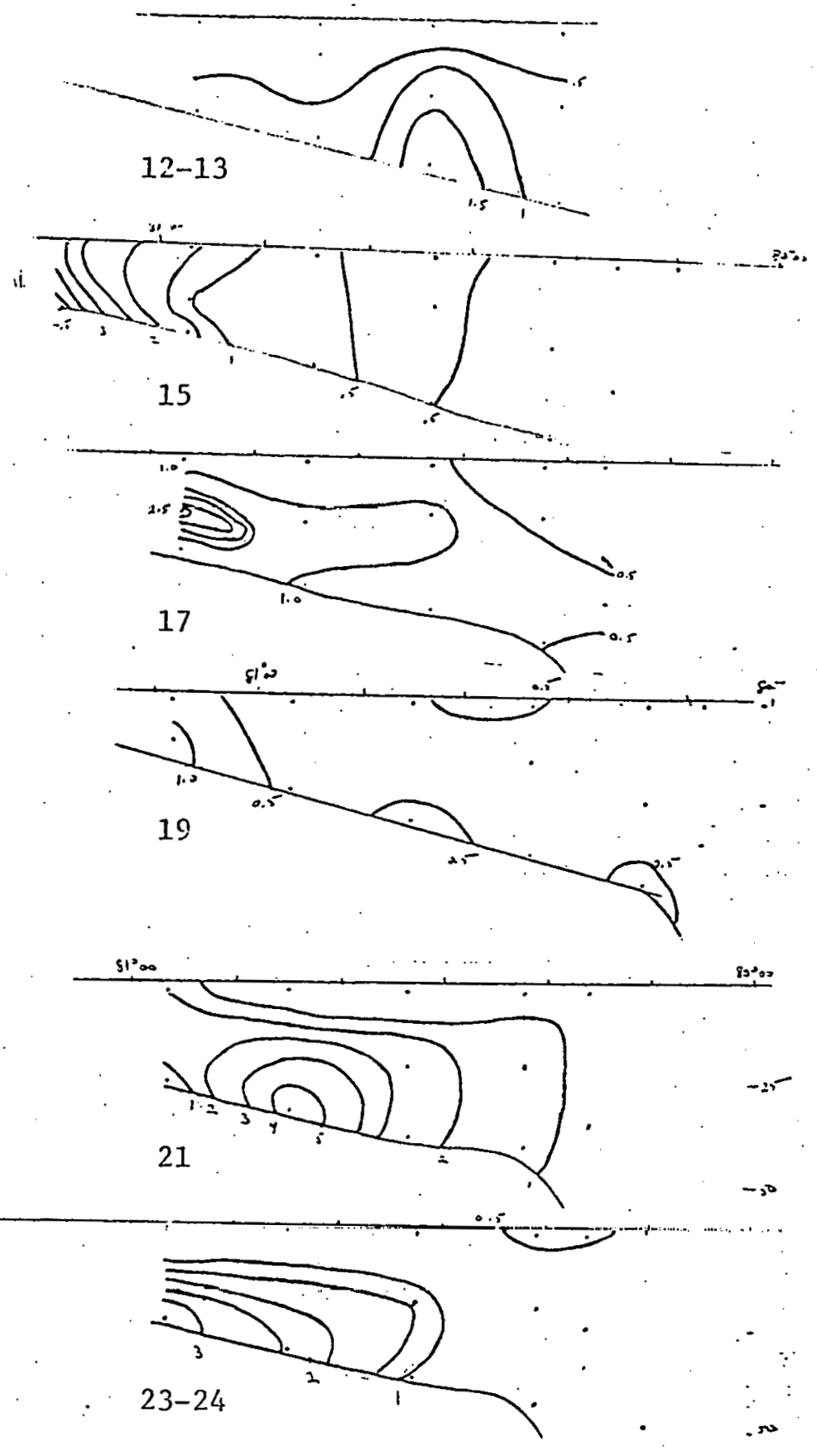

Figure 3, St. Augustine hydrographic section, CABEX I, April 12-24, 1980. Active chlorophyll a, micrograms per liter. 


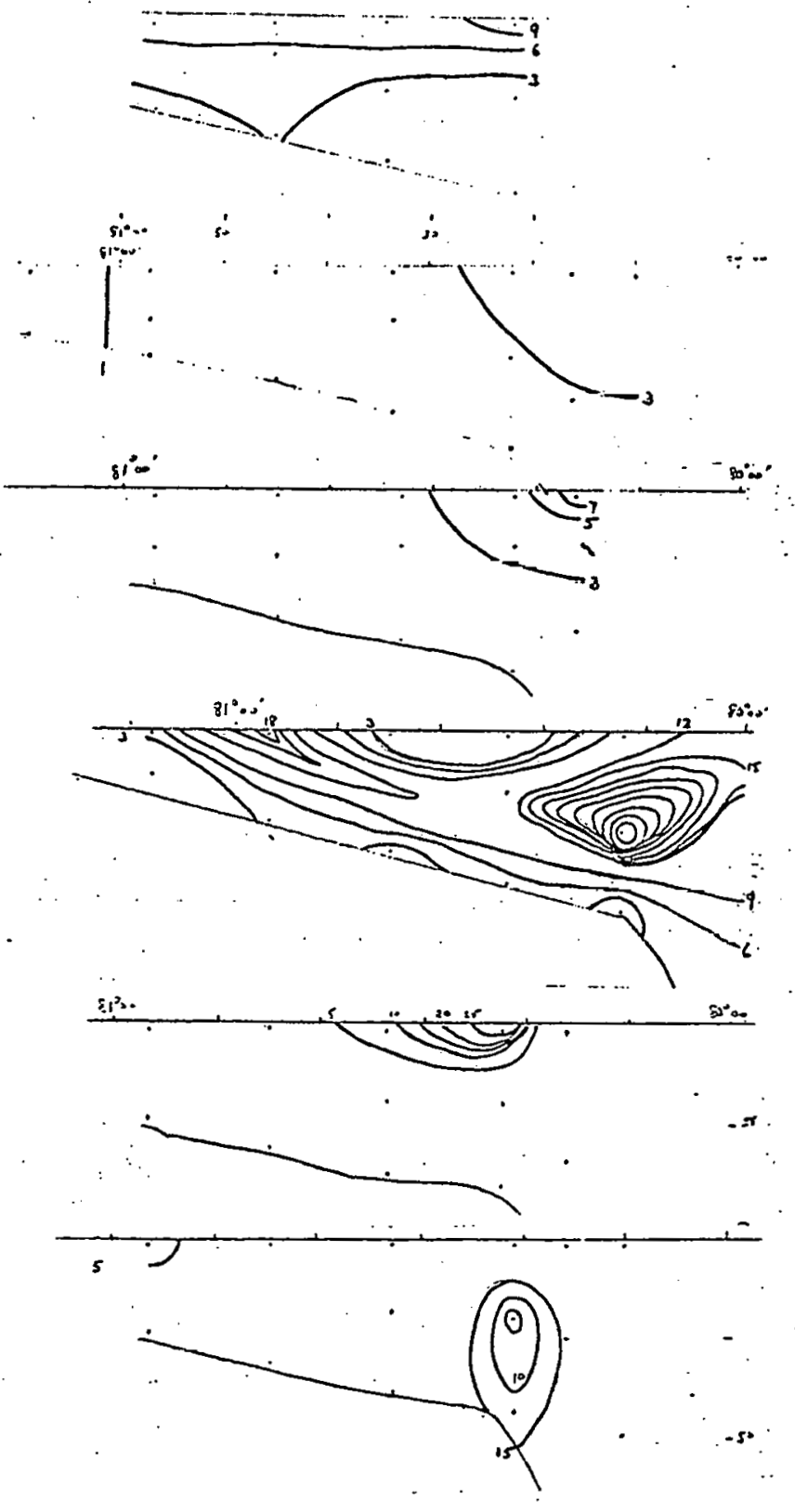

Figure 4. St. Augustine hydrographic section, GABEX I, ApriI 12-24, 1980. Heterotrophic-photoautotrophic index. 
The development of the phytoplankton bloom on the outer continental shelf in April, 1980 was unusually extensive and was not limited to the immediate vicinity of the intrusions. Probably this is related to the presence of brackish water moving across the shejf (Figure 2). On several occasions the bloom extended toward shore beyond the region of the outer shelf that we sampled (Figure 3), and it extended to the surface; or very nearly so in some cases. Day-to-day variation along the section was great, as it usually is on the outer shelf, because water is moving through the section as well as back and forth along it. For example, the absence of bloom conditions in the 19 April section should not be taken to indicate that the bloom seen on the previous section two days earlier had been dispersed or eaten by zooplankton. Rather, it was somewhere else.

The HP index (Campbell et al. 1979) shows autotrophic dominance of the microbial community over most of the shelf waters, including all bloom areas, with small patches of heterotrophic dominance outside the bloom areas. The exception is April 19, when heterotrophic dominance is ubiquitous. The extent of autotrophic dominance is in sharp contrast to typical intrusion situations uncomplicated by fresh-water runoff. Compare, for example the HP index distribution of April 1980 with the of April 20-21 (Figure 4).

The data presented in this report for GABEX $I$ are preliminary and incomplete. Data processing has not been completed at this time.

\subsection{Eastward Cruise E3B-79}

The EASTWARD cruise of August 7-14, 1979 (Brunswick, Ga. to Beaufort, N.C.) was focused on microbial processes in an intrusion off St. Augustine. This was a situation in which weak intrusions were coming with a high frequency. An intrusion which was located immediately upon arrival at the shelf break off St. Augustine, was already near its maximal advance over the shelf, with $15^{\circ}$ water at least $20 \mathrm{~km}$ west of the shelf break. Nitrate concentrations of $5 \mu \mathrm{g}$ atoms $\mathrm{N} / \mathrm{I}$ extended along the bottom to the west of our section (Figure 5). A midwater chlorophyll maximum above the thermocline or in it remained throughout the three days of observation. Counts of bacteria were done on every sample taken on the section for three days. Included in the enumerations were free minibacteria, large attached bacteria, flocculent aggregates, chroococcoid cyanobacteria, and phytoplankters. Two manuscripts based on the results of this cruise are included as parts of this report (Hodson et al. and 

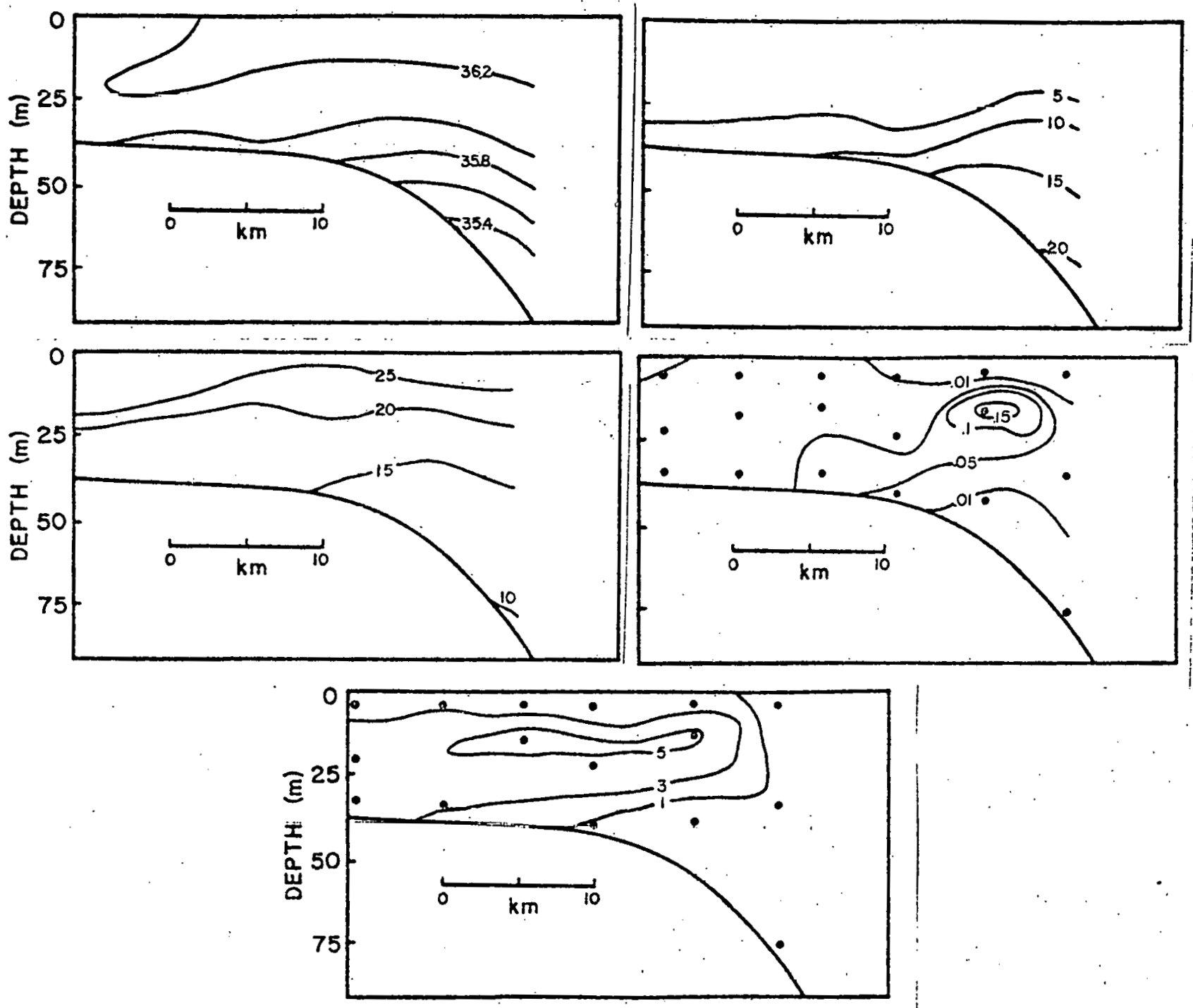

Figure 5. Hydrographic section of the continental shelf at $30^{\circ} \mathrm{N}$, August 10 , 1979. Left: salinity, \%oo (above); temperature, ${ }^{\circ} \mathrm{C}$ (below). Right: Nitrate, micrograms/liter (above); active chlorophyll a, micrograms/liter (below). Bottom: $10^{5}$ bacteria $/ \mathrm{ml}$. 

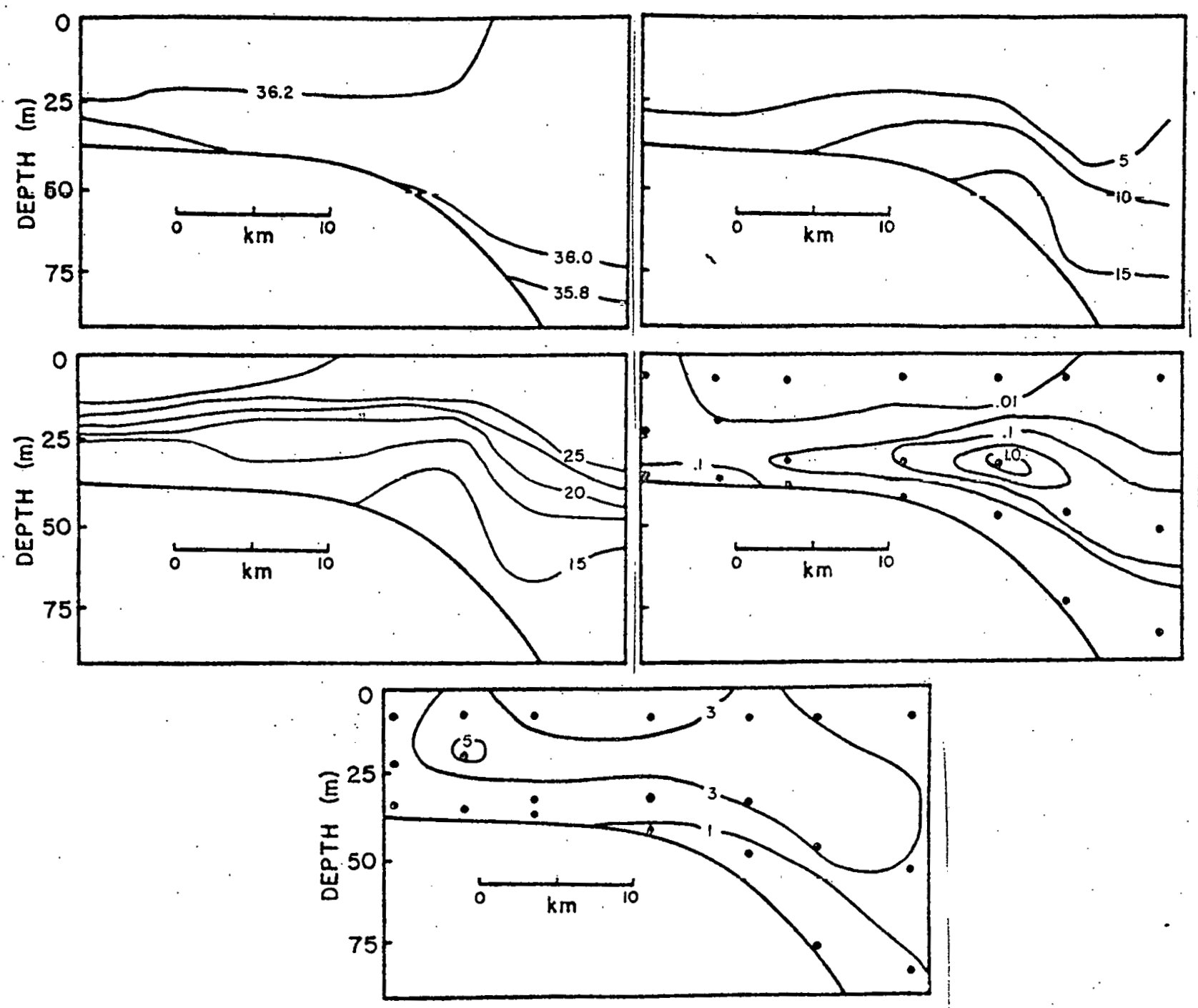

Figure 6. Hydrographic section of the continental shelf at $30^{\circ} \mathrm{N}$, August 11, 1979. Left: salinity, \%o (above); temperature, oC (below). Right: Nitrate, micrograms/liter (above); active chlorophyll a, microgramŝs/liter (below). Bottom: $10^{5}$ bacteria/ml. 


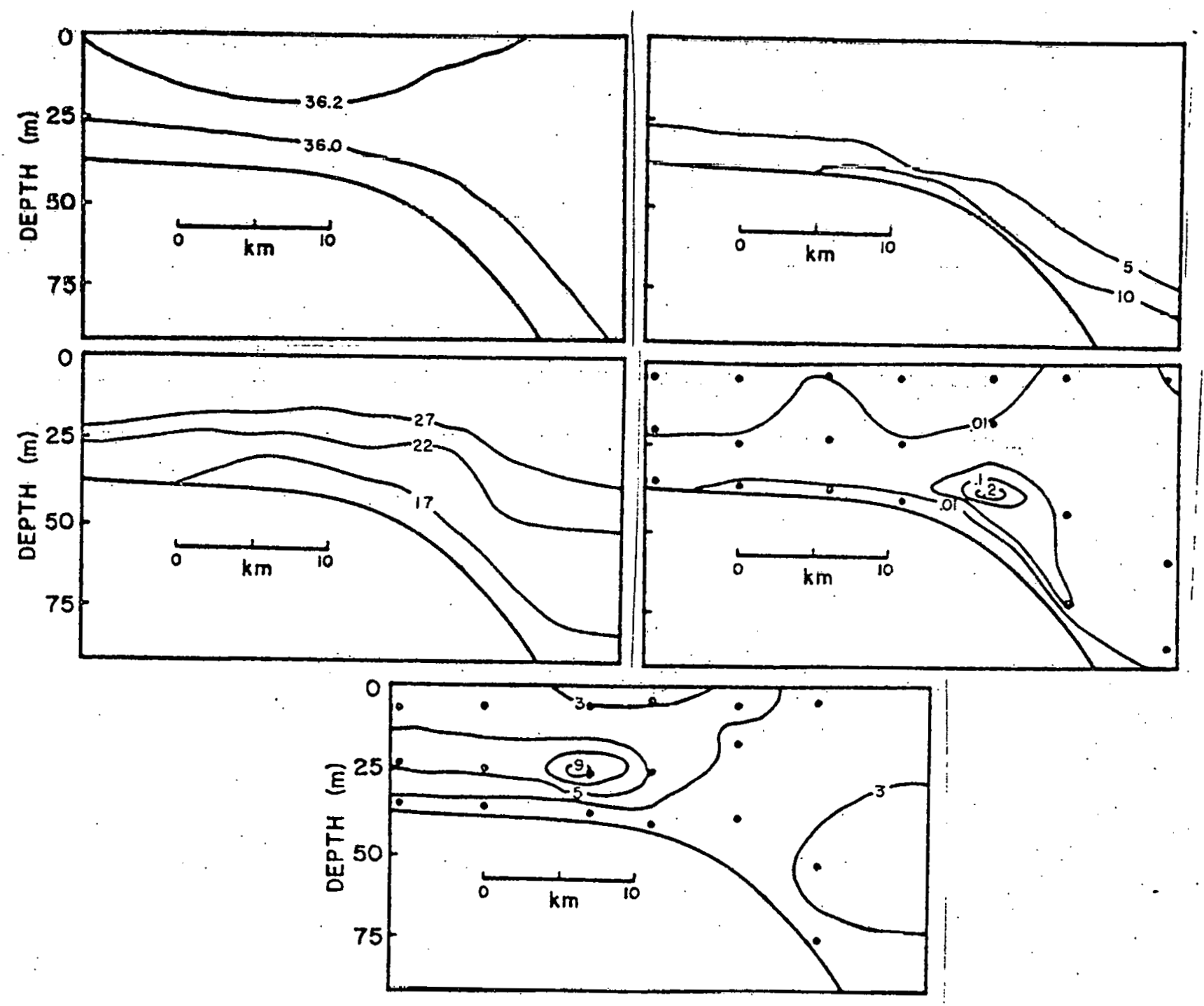

Figure 7. Hydrographic section of the continental shelf at $30^{\circ} \mathrm{N}$, August 11 , 1979. Left: salinity, \%oo (above); temperature, ${ }^{\circ} \mathrm{C}$ (below). Right: Nitrate, micrograms/liter (above); active chlorophyll a , micrograms/liter (below). Bottom: 105 bacteria/m1. 
Jacobsen), and the results are discussed further in section 3.2. If one can speak of a typical intrusion, this example approaches it, based on our experience to date. Although the bloom of both phytoplankton and bacteria was still. active when ship scheduling forced us to depart at the end of the third day, there was evidence that the intrusion was relaxing, and probably the whole thing went over the shelf break on the fourth day. Compare, for example, the isotherms and also the chlorophyll distribution on August 10 (Figure 6) and August 12 (Figure 7).

\subsection{R/V GILLISS cruise, April 19-May 2, 1979}

An intrusion at the shelf break due east of Jacksonville, Florida was followed for four days by running daily. sections at $30^{\circ} 20^{\prime} \mathrm{N}$ as the intrusion event moved northward through the position. This was a cooperative study involving Atkinson, Paffenhọffer, and Yoder. Physical and chemical data reported here were collected by Atkinson's group.

The high chlorophyll concentrations on April 21 and 23, with comparatively low concentrations on April 22, probably do not represent a sequence of events in the same water body but are the result of water movement through the section (Figure 8). However, the water on April 11 is under the influence of adjacent intrusion water, because it has unusually high adenylate concentration (Figure 9) due to heterotrophic populations (as indicated by HP index values in Figure 11). This is one of several instances where we have observed striking separation in space, but not in time, of blooms of autotrophs and heterotrophs. In contrast, the section taken on April 24 shows old shelf water or Gulf Stream water throughout the section. Chlorophyll is very low, adenylates are very low, adenylate energy charge is 0.6 or less everywhere, and HP index is below 3 everywhere. Although chlorophyll concentration increased by more than an order of magnitude during the intrusion event, energy charge data, used in conjunction with the HP index, suggest that the phytoplankton population as a whole was not growing actively and was suffering from some kind of stress. The only really high energy charge values occurred in the surface water on April 22, when the upper layer was heterotrophically dominated and chlorophyll was compaxatively low.

While the biological response to the intrusion of April 20-24, 1979 was not as intense as some others we have seen, it followed the typical course. Having probably originated on the 20th, when first observed on the 21 st there 


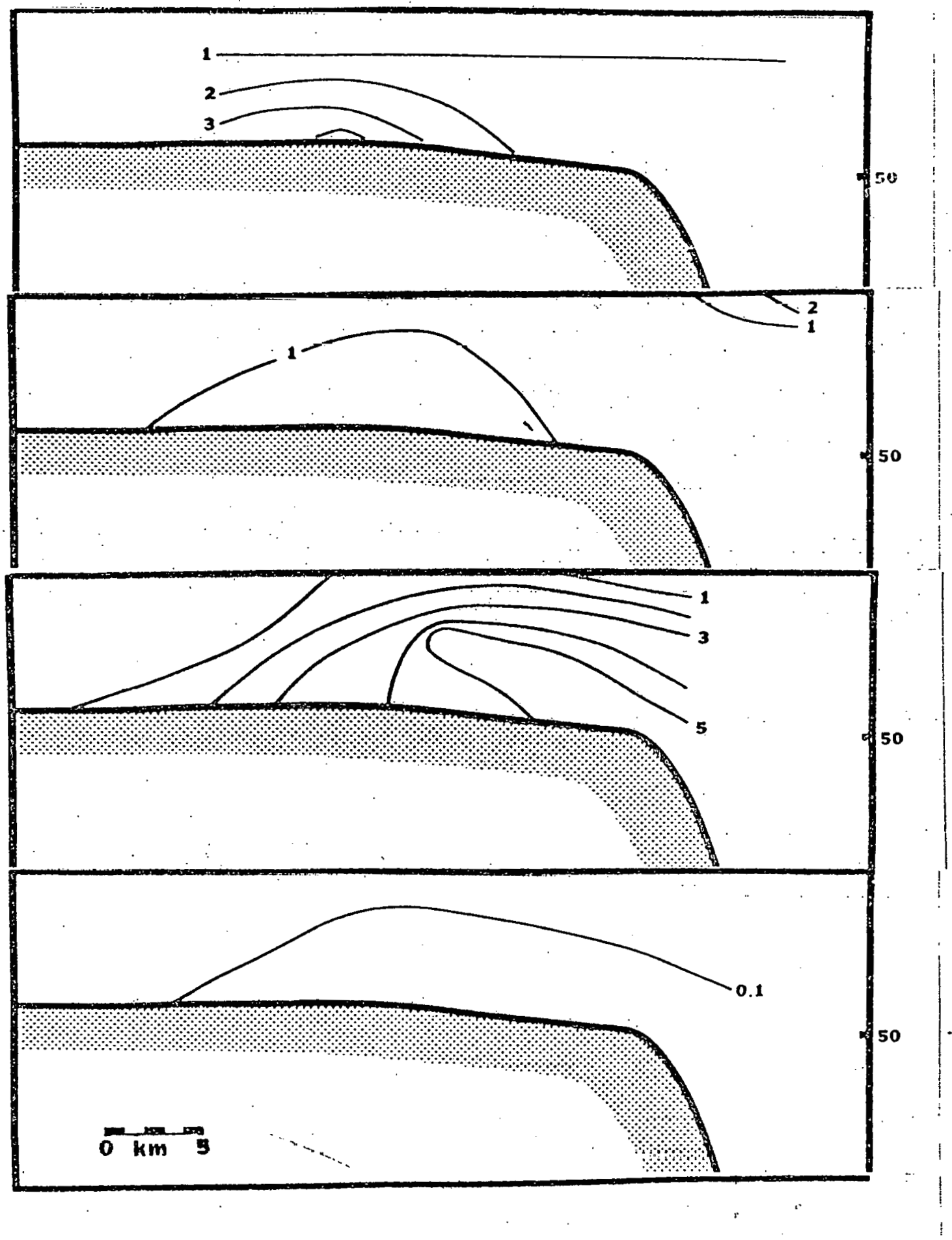

Figure 8. Distribution of active chlorophyll a, micrograms per liter, on a section of the continental shelf at $30^{\circ} 20^{\prime} \mathrm{N}$, April 21 (top) to. 24 (bottom), 1979. 


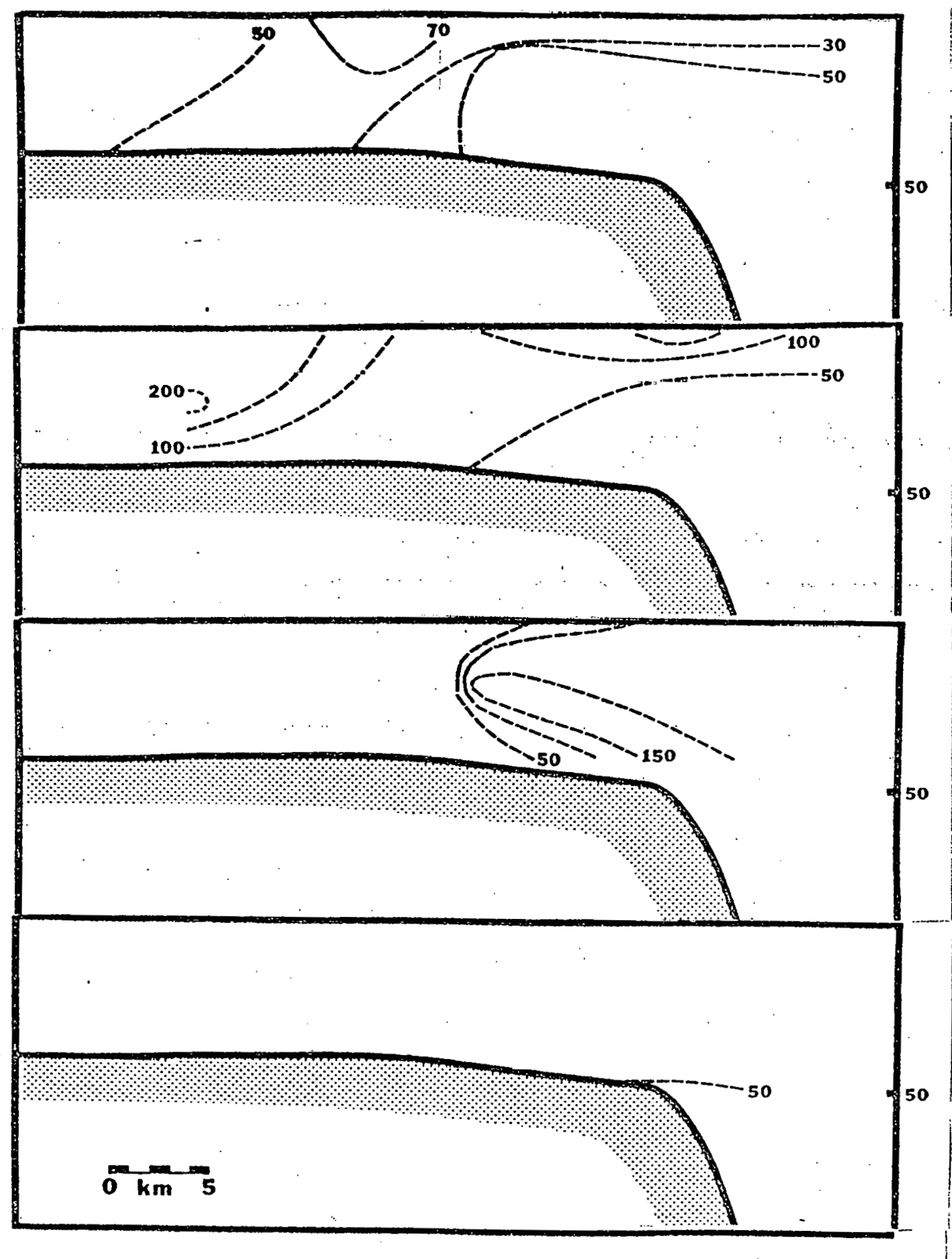

Figure 9. Distribution of particulate total adenylates, ATP, ADP, and AMP $\left(10^{-11}\right.$ moles $)$ on a section of the continental shelf at $30^{\circ} 20^{\prime} \mathrm{N}$, April 21 (top) to 24 (bottom), 1979. 


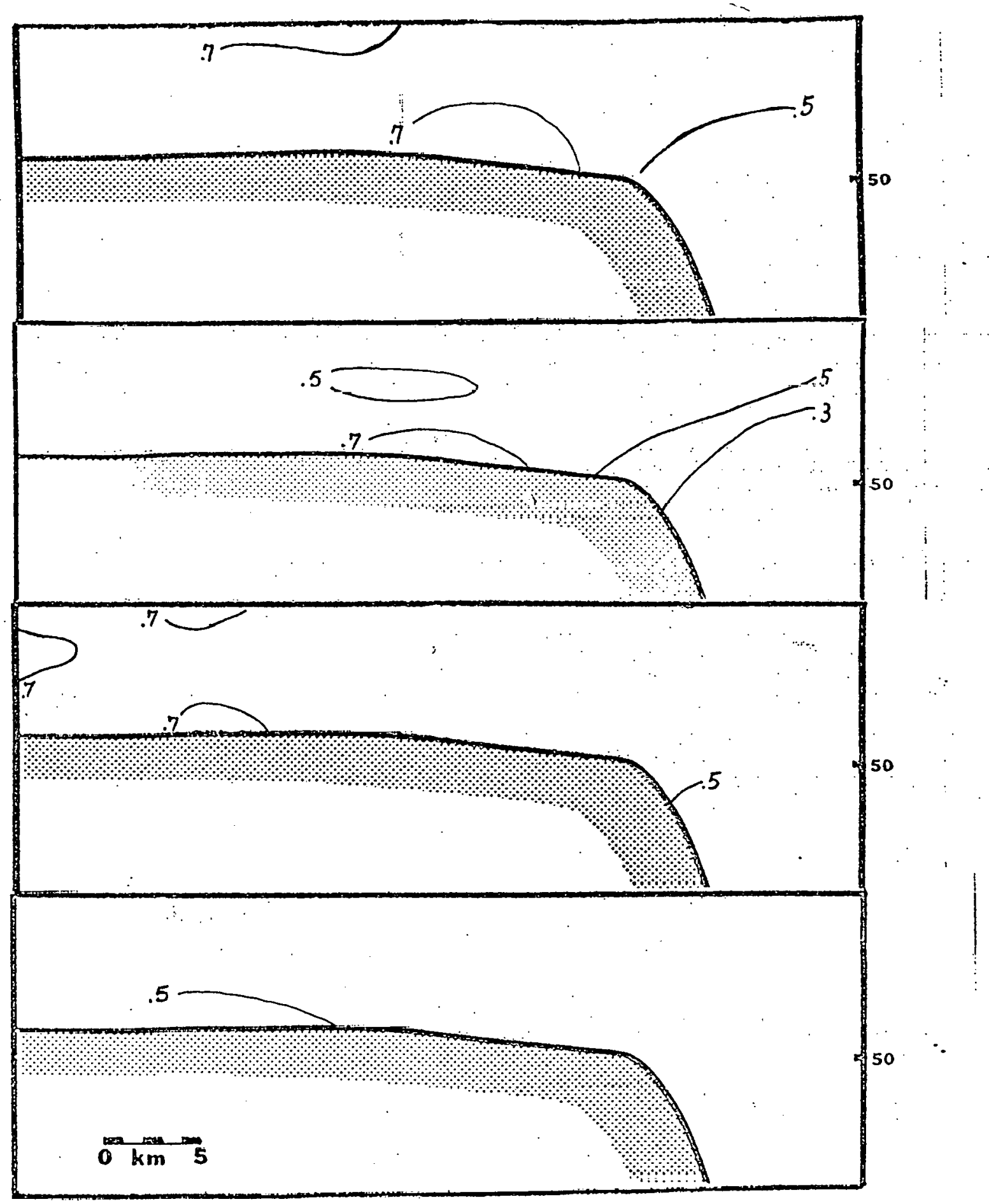

Figure 10. Energy charge ratio on a section of the continental shelf at $30^{\circ} 20^{\prime}$, April 21 (top) to 24 (bottom), 1979. 


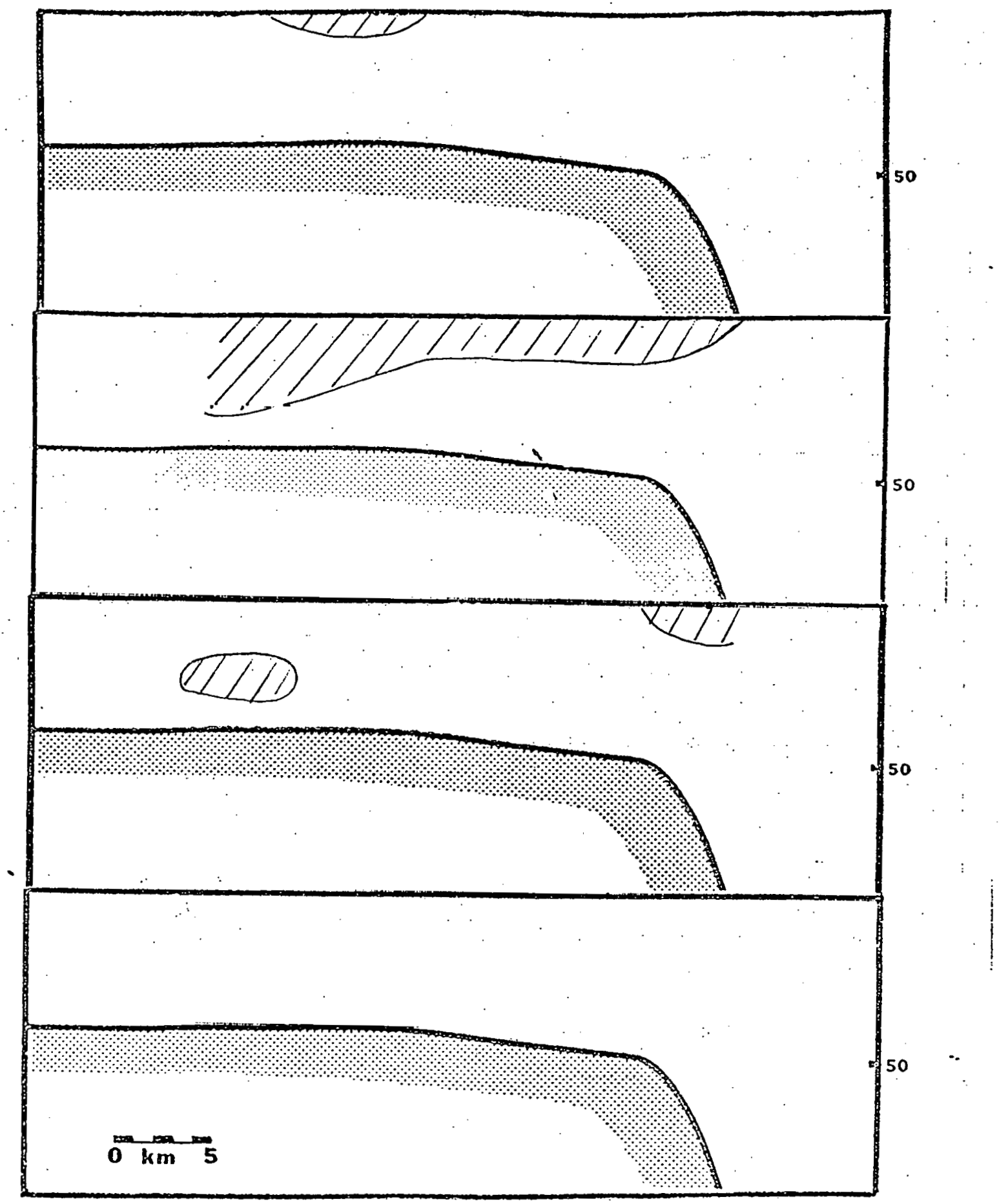

Figure 11. Heterotrophic-photoautotrophic index on a section of the continental shelf at $30^{\circ} 20^{\prime} \mathrm{N}$, April 21 (top) to 24 (bottom), 1979. Hatched area is mixed autotrophic-heterotrophic biomass $(\mathrm{HP}>3<10)$. Unshaded area is autotrophdominated biomass (HP $<3$ ). 
was already a substantial phytoplankton bloom centered in the intruded Gulf Stream water near the bottom. Patches of less nitrate-rich water, such as that passing through the section on April 22, were nevertheless influenced by productivity in the adjacent water because they contained abnormally high concentrations of adenylates of heterotropic origin and showed a high energy charge ratio attributable to the population of heterotrophic bacteria. On April 23 the intrusion was beginning to relax, with some cascading of water over the shelf break. This is seen in the distribution of adenylates and. chlorophy11. On April 24 the event had wholly passed by and the section was occupied by low-nutrient water of low biological activity and biomass.

\subsection{R/V ISELIN Cruise April 25-24, 1978}

This was the first combined cooperative'cruise by the intrusion research group, in which physical, chemical, and biological oceanographers combined efforts on the study of a single intrusion event. Using satellite imagery, an intrusion was located east of Brunswick, Georgia, and a section was run on two successive days: The first day was that of maximai intrusion, and the water was moving over the shelf break on the second day. This was the first use of our concept of the heterotrophic-photoautotrophic index (HP index) as a qualitative indicator of the relative dominance of autotrophs and heterotrophs in water samples. Data from this cruise, together with a description of the HP index and the rationale behind it are published in the paper by Campbell et -al. (1979) which is a part of this report.

While this cruise was short, and only two consecutive sections were run through an intrusion, it was important in establishing a research strategy which has proven very successful for us. This involves the cooperative use of a ship by physical, chemical, and biological contractors, satellite data to locate the Gulf Stream and eddies on the west wall (at least in seasons when temperature differences make this possible), and running daily hydrographic sections at an establsihed latitude. Each station is sampled only once, using an STD and rocttc samplcr, with all scicntists using watcr from the single cast.

\subsection{R/V ISELIN Cruise August 3-10, 1978.}

This was a cooperative cruise whose purpose was to follow a stranded intrusion. August is the most favorable time for stranding of intrusions, and 

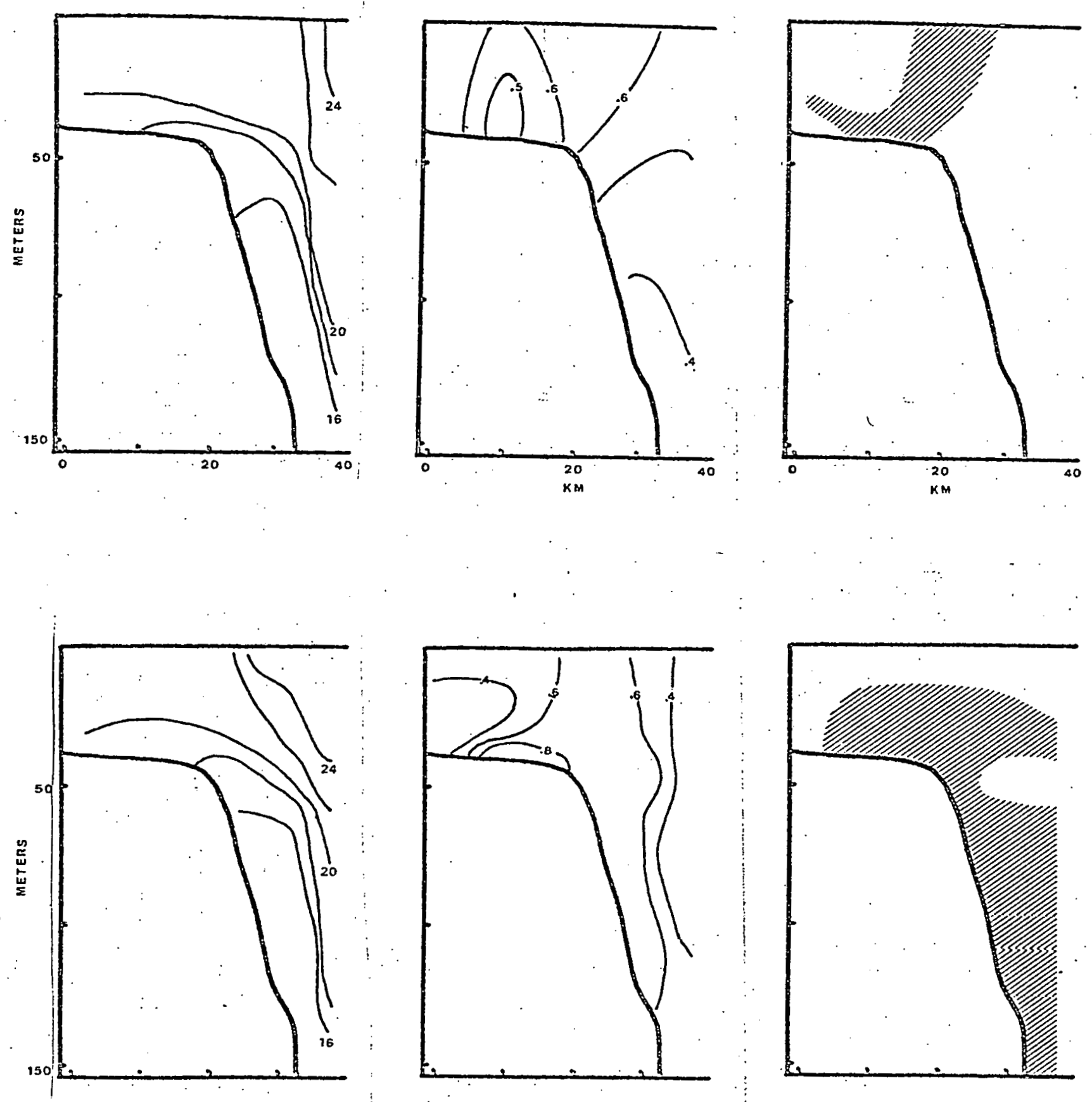

Figure 12. Indices of microbial activity in an intrusion of Guif Stream water on the outer continental shelf, $30^{\circ} \mathrm{N}$, April 21 (top) and 22 (bottom), 1978. Left, temperature, ${ }^{\circ} \mathrm{C}$; center, adenylate energy charge; right, heterotrophic-photoautotrophic index. Shaded portion is dominated by autotrophic biomass (HP index $<3$ ). Unshaded portion is mixed autotrophic and heterotrophic blomass (III index 3-10). 
indeed one was found off Fernandina which we were able to follow over several days. Unfortunately, it is difficult to set up a two-dimensional sampling regime, such as that used for intrusions at the shelf break, because the movement of stranded intrusions is slow and unpredictable. Moreover, they lie on the bottom, so there are no surface clues. Satellite imagery does not help. We have since developed a towed subsurface thermistor, but at that time the only approach was many STD or XBT casts. Attempts to follow a specific water body with a drogue were of limited success, apparently because of the shear between the intrusion and the overlying shelf water. Therefore, continuity of sampling was not satisfactory.

From the point of view of the DOE mission, this was a useful experience in that it gave us good insight into water movement on the continental shelf. Movement is comparatively. slow in the absence of forcing from the Gulf Stream, but when stratification is present surface and bottom waters may nnt he moving Lugether.

\section{Coastail Fronts}

Density fronts are a feature of the ocean which has long been recognized. The importance and ubiquity of mesoscale density fronts has been appreciated relatively recently (Savidge and Foster 1978; Floodgate et al. 1981). The water of the inner continental shelf of the southeastern U.S. is well mixed vertically, but it is segmented horizontally by a number of density fronts. The fronts are often prominent on satellite imagery. They can usually be seen from the bridge of a ship as well. This is because the water on the coastal side of a front is typically more turbid. In fact, differences in salinity and temperature are small across most of the fronts, often less than $1 \%$ and $1^{\circ} \mathrm{C}$, which suggests that most of the density difference is caused by the suspended sediments themselves. The fact that there are significant density differences across the fronts is demonstrated by the presence of a convergence at the front, marked by a foam line. While not much seems to be known about their formation, they appear to form in the first 5-10, kun of the ocean. Probably they have a lifetime of one to several days ( $J$. Imberger, pers. comm.). Fronts influence the flux of materials, as well as water itself, across the inner continental shelf (Blanton 1980; Blanton and Atkinson 1978). To evaluate that flux and its chemical and biological impact, a. series of 
cooperative studies have been undertaken which are planned and coordinated by J.0. Blanton.

Three cooperative studies have been completed, and a fourth is planned for April 1981. The first, in 1977, was an anchor station in Wassaw Inlet to evaluate transport through the frontal zone. Two persons from this research group participated in the collection of data. In 1978 two vessels, R/V KIT JONES and R/V BLUE FIN, were anchored in the Wassaw Inlet area. Four persons from our research group participated. In 1979 two vessels, R/V BLUE FIN and $\mathrm{R} / \mathrm{V}$ ISELIN, were anchored inthe Wassaw Inlet area. Five persons from our research group participated. The latter two studies are described in the following eections. It must he emphasized that these studies, at least from our point of view, are preliminary in nature. The objective is as much to define the system as to actually measure it.' For this reason we have tried many things, sometimes collecting only partial data sets, to ascertain what measurements will be useful.

\subsection{Cooperative Front Study, May 9-12, 1978}

Participants in the study included J.O. Blanton, H. Windom, and D. Hayes: The overall objective of the project was to measure water flux through the region of the coastal front off Wassaw Inlet. The primary objective of all participants was to evaluate various tracers of water movement, including tritium (Hayes), trace metals (Windom), and such biological parameters as chlorophyl1, pheophytin, and adenylates (Pomeroy). BLUE FIN and KIT JONES were anchored for four tidal cycles in positions which we hoped would provide sequential sampling of the Savannah River plume. The positions and a summary of the physical data are given by Blanton (1979). Measurements of active chlorophyll a, ATP, and total adenylates were made at several depths every two hours. Sampel depths were based on temperature and salinity profiles from a CTD cast to place the water samplers in distinct upper and lower water layers associated with the frontal convergence. In addition, in vivo fluorescence was measured with a Turner Designs fluorometer equipped with a submersible pumping system.

Plots of in vivo fluorescence against time (Figure 13) suggest that the tow vessels were seeing different water bodies, and the physical data support this. Location A was in the Savannah River plume, while location $B$ was in the Ogeechee River plume as well as frontal and nearshore circulation. The dif- 

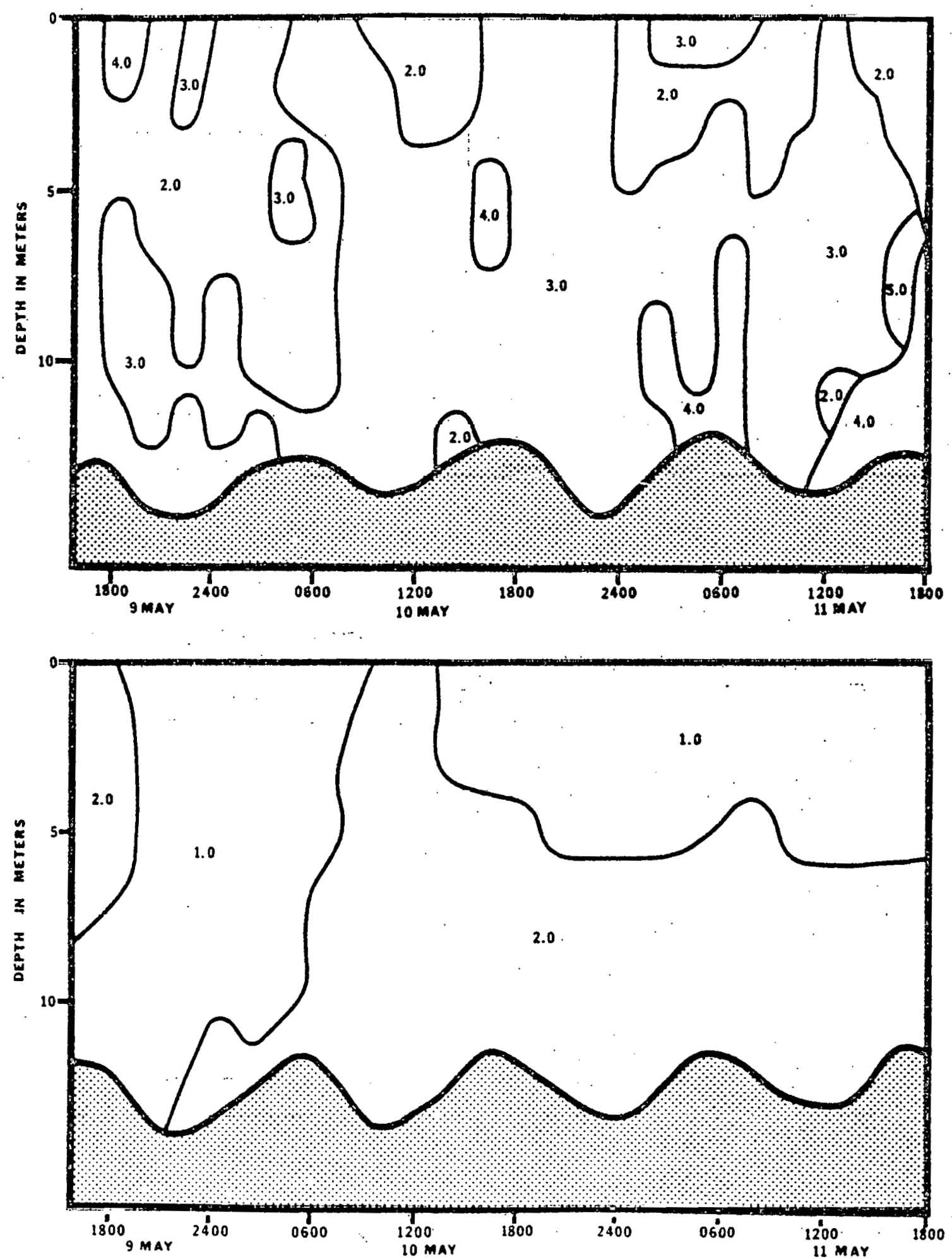

Figure 13. In vivo fluorescence time series at anchor stations off Wassaw Inlet, May 9-11, 1978. Top: R/V BLUE FIN. Bottom: R/V KIT JONES. Calibrated against purified chlorophyll a. 

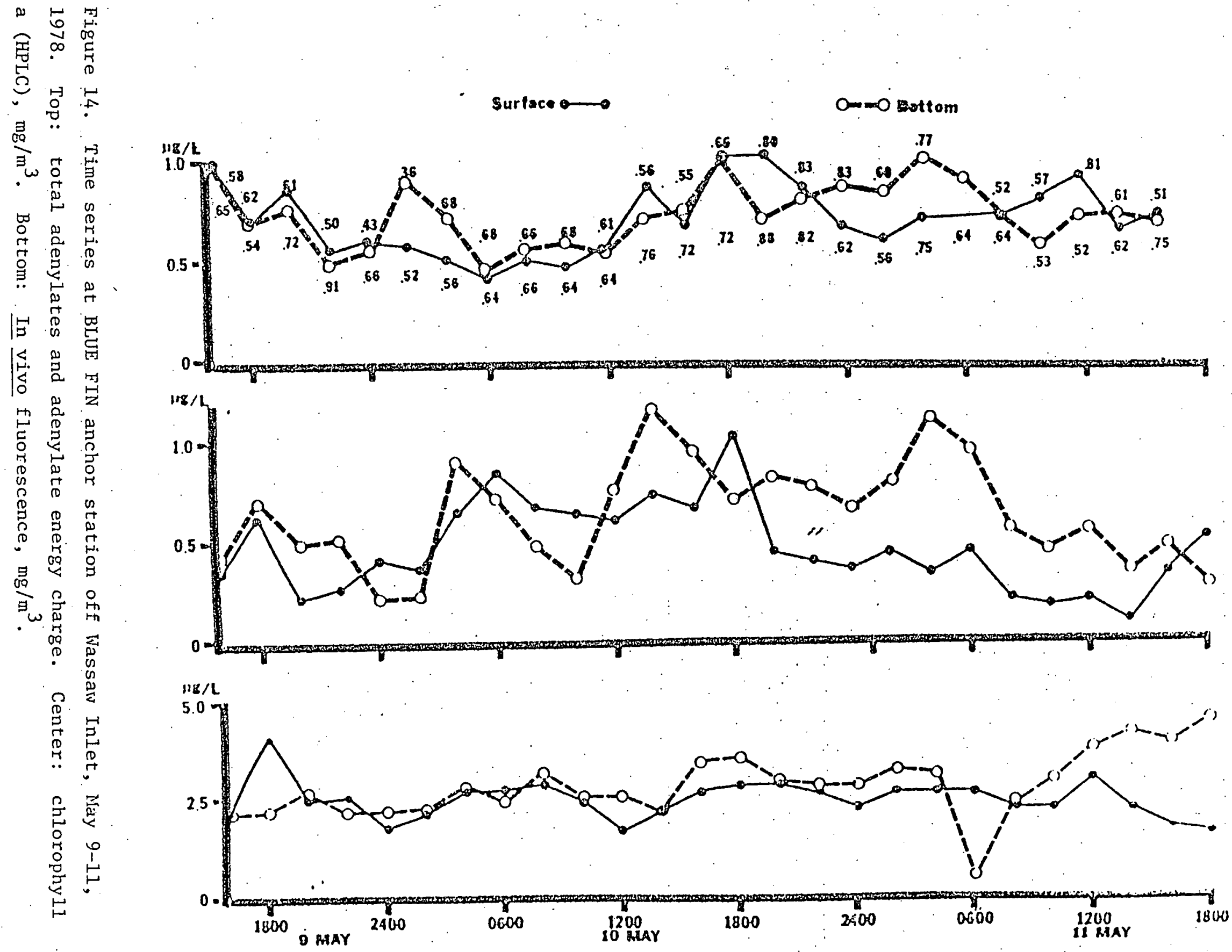


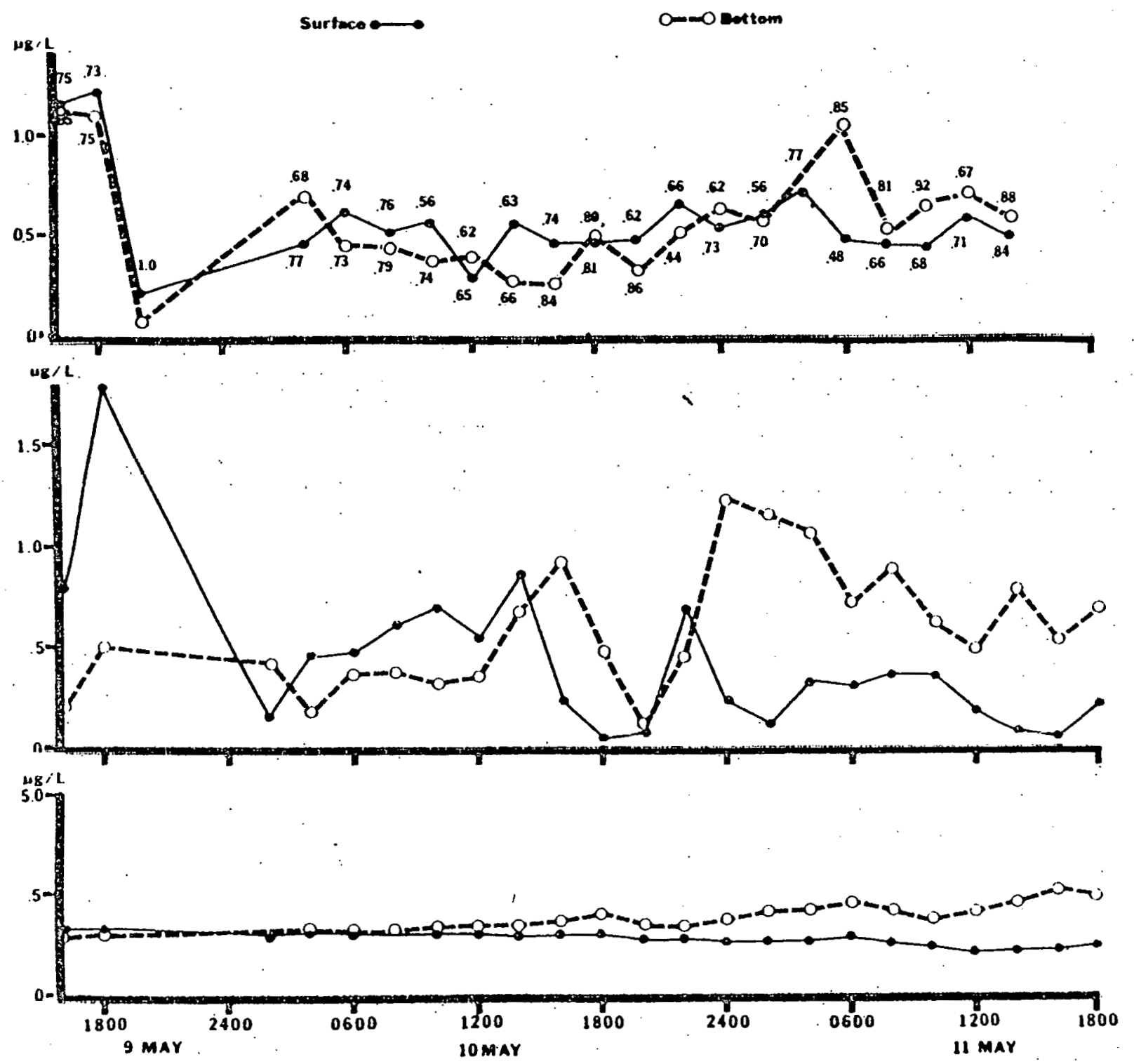

Figure 15. Time series at KIT JONES anchor station off Wassaw Inlet, May 9-11, 1978. Top: Total adenylates and adenylate energy charge. Center: chlorophyll a (HPLC), ing $/ \mathrm{m}^{3}$. Bottom: In vivo fluorescence, $\mathrm{mg} / \mathrm{m}^{3}$. 
ference between fluorescence of in vivo "chlorophyll" and active chlorophyll a measured by the method of Jacobsen (1978) in the time series (Figures 14 and $15)$ is striking. In vivo fluorescence at location A remained relatively constant at about $2.5 \mu \mathrm{g} / 1$, while active chlorophyll a was only about $0.5 \mu \mathrm{g} / 1$ but with considerably more variation. The higher concentrations of active chlorophyll a in the bottom samples probably represent highly active phytoplankton which have recently been carried down in the frontal convergence.

While active chlorophyll a is demonstrably a superior parameter of phytoplankton biomass and is useful in understanding the movement of phytoplankton in the frontal zone, in vivo chlorophyll fluorescence was the more useful indicator of different water bodies in this instance. The difference between in vivo chlorophyll fluorescence at location $A$ and location $B$ is one of the best indications that the two vessels were seeing different bodies of water.

\subsection{FRNFLX I, November 6-9, 1979.}

Two vessels were placed in Wassaw Inlet, one seaward of the other so water would move directly from one station to the other. Their distance was such that some of the same water would be sampled by both vessels. Replacement of the very small and cramped KIT JONES with $R / V$ ISELIN made it possible to have more technical assistance, to undertake more elaborate kinds of measurements, and to set up the Zeiss epifluorescence microscope to look at living microbial samples during the anchor station. Rather than focusing on the identity of water bodies, our goal during this study was to evaluate a number of microbiological parameters which might be indicative of biomass or activity in the nearshore zone. Some of the parameters which had been most useful in our work on Gulf Stream intrusions proved to be of less interest in the nearshore zone, while others showed considerable promise tor tuture studies. In several cases we took only partial data sets during the five tidal cycles of the study. This permitted us to examine more parameters. As in the offshore work, we were limited by the number of personnel the vessels could accomodate. Absolute numbers of bacteria are nearly an order of magnitude higher in the nearshore zone than in the water of the outer continental shelf. The numbers vary relatively little. In this study the range was from 0.9 to $3 \mathrm{x}$ $10^{6} / \mathrm{ml}$ (Figure 17). Most of the bacteria are free-living. Those on particles are much fewer but they are more variable in number. Based on our experience 
on this and several other coastal cruises on R/V BLUE FIN, it is necessary to prepare a separate sample, in which more water is filtered, to get a statistically significant count of attached bacteria. There may in fact be some difficulty in getting enough material on the slide for a significant count without incurring a coincidence loss effect from. clumping of particulate material. Based on this experience we conclude that counts of total bacteria are not a useful parameter to measure, at least in coastal Georgia, because biomass varies little. If you've seen one sample, you've seen them all... The alternative approach to measuring microbial biomass, which we found to be quicker and equally precise on the outer continental shelf, is the measurement of ATP or total adenylates. In the nearshore zone we found that. total adenylates varied little. Moreover, the H-P index shows that most of that biomass, most of the time, is phytoplankton (Figures 16-17). Therefore, adenylate measurements are telling us essentially the same thing as chlorophyll a measurements in this water. Moreover, energy charge calculated from the adenylate measurements is in most cases that of the phytoplankton. We cannot ascertain the energy charge of the bacterial population in the presence of so many phytoplankton. For these reasons we probably will not measure adenylates in the future in studies of the nearshore zone in Georgia.

Chlorophyll a measurements showed more phytoplankton in the bottom layer than in the surface (Figure 17and 18). Measurements of photosynthetic potential showed these phytoplankters near the bottom to have a higher potential than those near the surface, all being exposed to the same, moderate illumination from a fluorescent light source (Figure 17). Evidently the phytoplankton in the bottom water have recently been drawn down in the frontal convergence. However, something more than that has occurred to increase their photosynthetic potential. Enhanced nutrients seem unlikely in this nutrient-rich coastal water. Possibly there is an infusion of a different phytoplankton population from the other side of the front. While the measurement of photosynthetic potential produced some interesting and unexpected results, probably it is not an item of high priority for future work in the frontal zone.

Heterotrophic uptake of ${ }^{14} \mathrm{C}$-labeled glucose showed as much variation as any parameter of microbial activity we investigated (Figure 17). It varied a full order of magnitude over the course of the three tidal cycles in which the measurements were done. This makes heterotrophy a parameter of interest for 

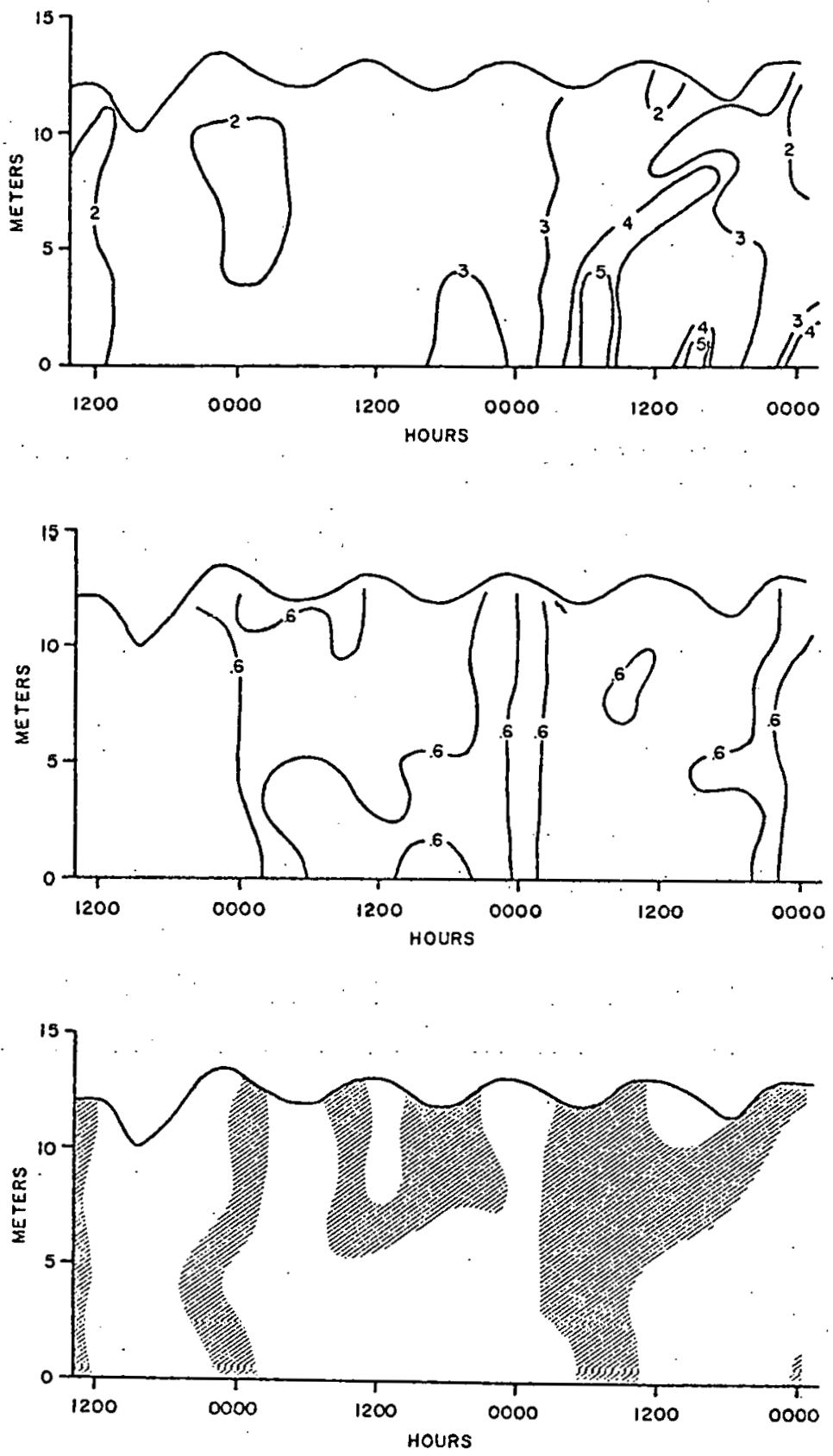

Figure 16. FRNFLX I anchor station A, 7-9 November, 1979. Top, total adenylates. Center, adenylate energy charge ratio. Bottom, heterotrophicphotoautotrophic index. Shaded areas are mixed autotrophic-heterotrophic biomass $(H P>3<10)$. Unshaded areas are autotroph-dominated $(H P<3)$. 

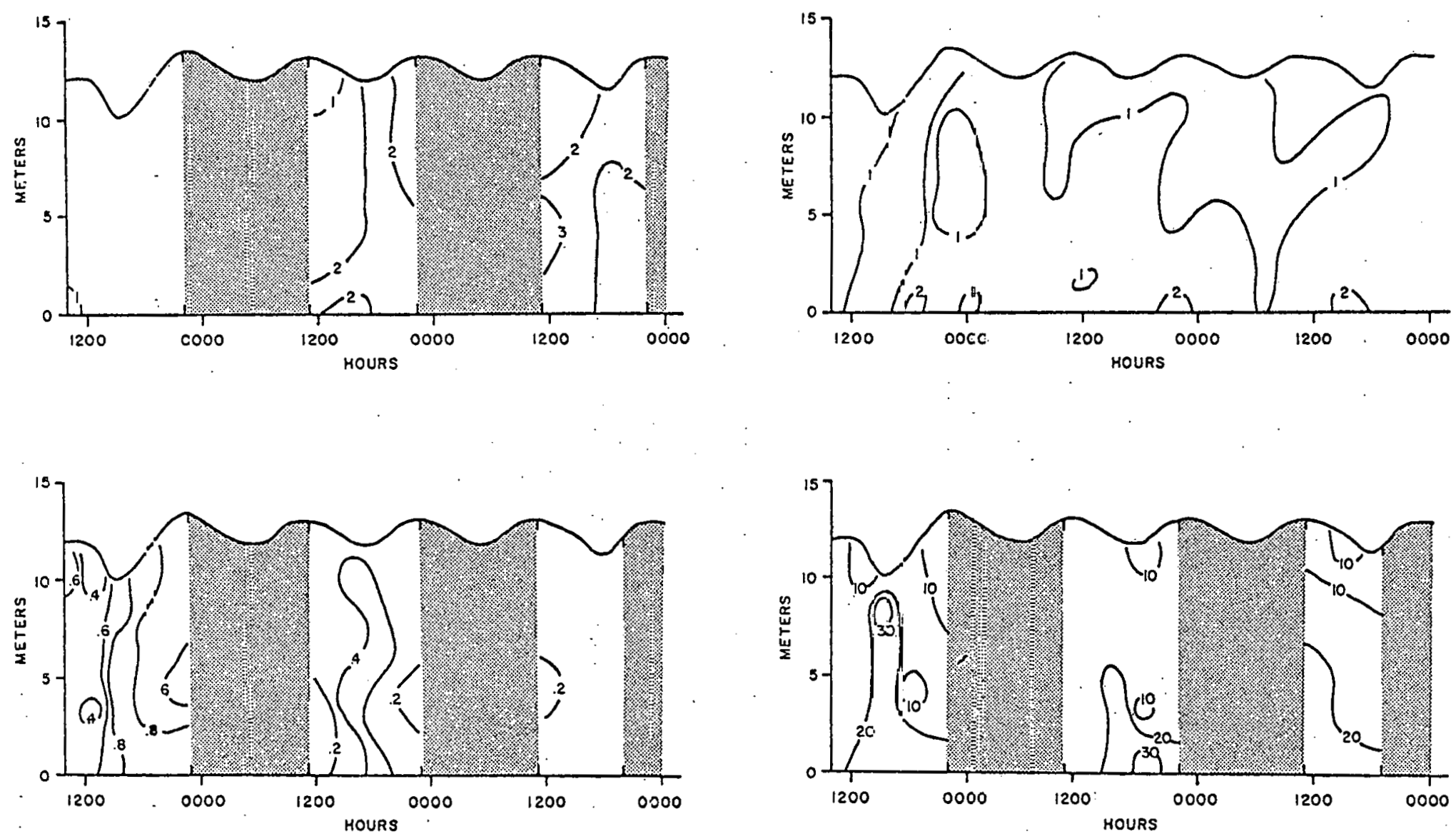

Figure 17. FRNFLX I anchor station A, 7-9 November, 1979. Top left, AO counts of total bacteria, $10^{6} \mathrm{cells} / \mathrm{ml}$. Bottom left, heterotrophic uptake of ${ }^{14} \mathrm{C}$-labeled glucose, $\mu \mathrm{g} \mathrm{C} 1^{-1} \mathrm{hr}^{-1}$. Top right, chlorophyll a, $\mathrm{mg} \mathrm{m}^{-3}$. Bottom right, potential photosynthesis, $\mathrm{mg} \mathrm{C} \mathrm{m}^{-3} \mathrm{hr}^{-1}$. Shaded portions are times when samples were not taken. 

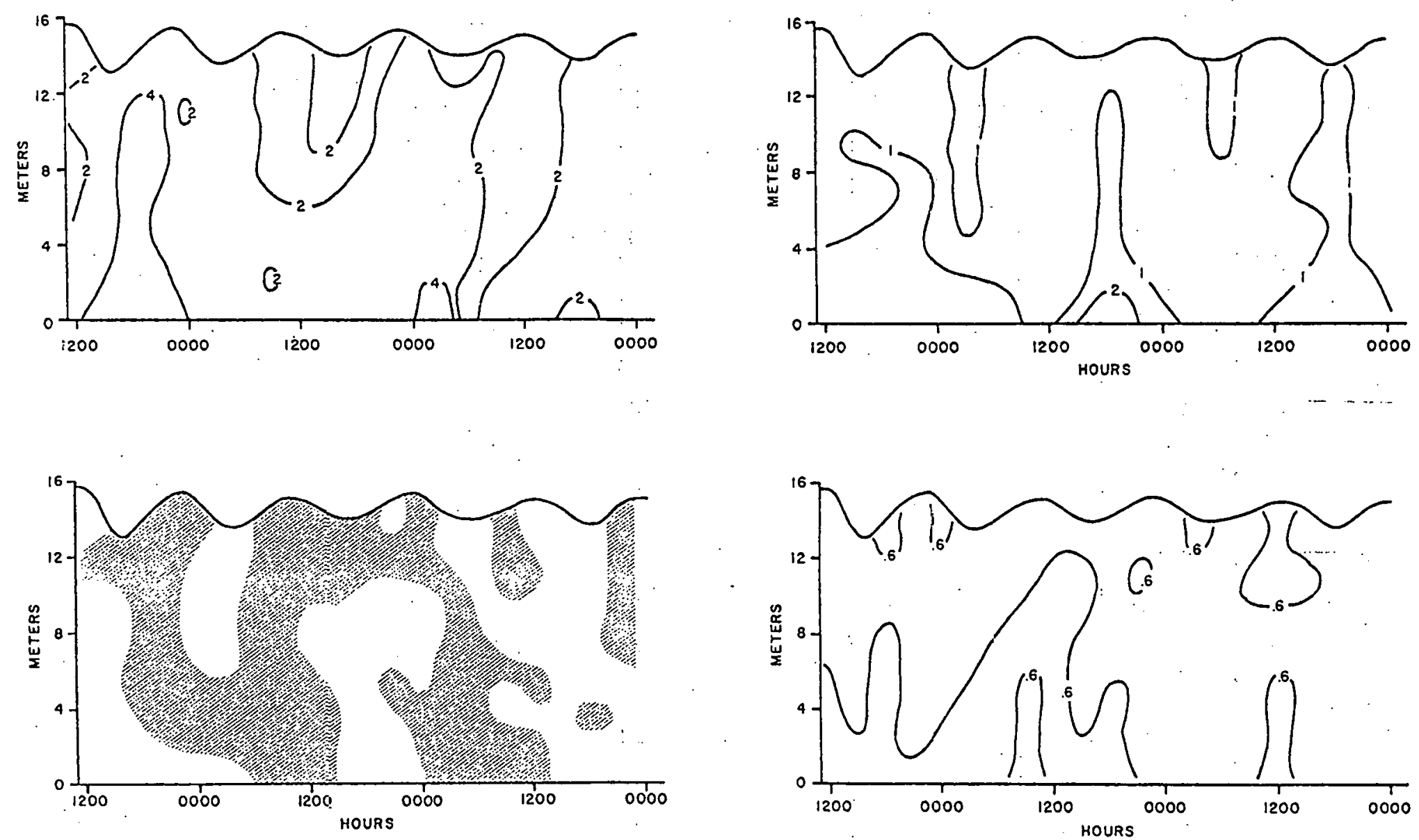

Figure 18. FRNFLX I anchor station B, 7-9 November, 1979. Top left, total adenylates. Bottom left, heterotrophic-photoautotrophic index. Shaded portion is mixed autotrophic-heterotrophic biomass (HP $>3<10$ ). Remainder is autotrophicdominated biomass (HP <3). Top right, chlorophyll a, $\mathrm{mg} \mathrm{m}^{-3}$. Bottom right, adenylate energy charge. 
future studies: Uptake of labeled glucose, however, may not be the best possible approach. It is not indicative of total uptake of organic matter, and probably it underestimates it by more than an order of magnitude (Wiebe and Smith 1979). While routine use of even an abbreviated measurement of uptake of a defined labeled compound is almost prohibitively time consuming for a fast-paced series of samples at an anchor station, the possibly more realistic approach of Smith and Wiebe (1978) of using labeled naturally occurring dissolved organic compounds (but chemically undefined) is even more time. consuming. Perhaps the ideal parameter would be the measurement of respiration, although this would have a substantial phytoplankton bias. We shall probably consider doing that if a method can be set up that is sufficiently sensitive without being too time consuming for sampling closely spaced in time.

3. Microbial Populations and the Detritus Food Web

Because this contract is concerned with the flux of energy and materials, particularly as mediated by microorganisms, in the water over the continental shelf, it is concerned with the production and fate of particulate and dissolved organic matter that is non-living as well as living. While this work emphasizes the non-living components to some degree, any complete separation of living and non-living. would be artificial and unworkable. Iherefore, we have to begin with primary production, as do Paffenhöfer and Yoder, who are concerned with the flux of energy through the zooplankton. We also have to consider some aspects of zooplankton ecology, particularly the production of fecal material which is a major input of non-living particulate organic matter to the system. Since we are working cooperatively in a coordinated research program, unnecessary duplication can be avoided.

The flux of energy through non-living components of the pelagic ecosystem involves both very rapid responses and stabilizing influences. The dissolved organic matter, produced both as a primary source by phytoplankton and as a secondary energy source by zooplanklun and bacteria, is utilizcd by bacteria very rapidly. In fact, utilization is so rapid that evaluation of the rate of production of DOM is difficult. This is one of several reasons why its significance as an energy flux in planktonic ecosystems has been underestimated. Most of the particulate matter in the sea is non-living, indicating that much of it has a comparatively long residence time in the water. Since it is both 
a substrate and a structural component of the environment for microorganisms, its production and fate are important considerations. However, we know surprisingly little about the non-living seston. Both biological and abiotic origins have been postulated (Riley 1963; 1970; Wiebe and Pomeroy 1972; Zimmermann 1977; Pomeroy and Deibel 1980). Probably both occur in the real world, but the actual rates are not known. Chemical analysis of seston has been of little help, because all of it probably originates from phytoplankton, and therefore its chemistry is all much alike and like the phytoplankton. themselves. While it is not the major thrust of this contract to develop new ideas or data on the detritus food web for its own sake, these are questions which have to be taken into consideration in our interpretations of processes on the continental shelf. In the course of understanding processes on the southeastern continental shelf some new ideas and information on the detritus food web have emerged.

The turnover of dissolved organic matter and its relation to bacterial populations in the water has been examined. The nature, source, and fate of particulate seston has been re-examined, and some of it identified as the fecal material of zooplankton. A simulation model of the food web as been constructed which includs the major features of the flux of dissolved organic matter and detritus.

\section{3:1 Methods of Microscopy.}

Although we are routinely using the acridine orange epifluorescence method for counting marine bacteria, it does have some limitations, and we are continually exploring new methods. We have modified the acridine orange method somewhat to increase the time samples can be stored before they are counted. This is a significant problem. It is not feasible to count samples in large numbers at sea. They must be brought back to the laboratory and counted later. Samples preserved in formalin last only about two weeks after collection, not long enough to count a large set. We have extended the storage time to about six weeks by preserving the samples in buffered glutaraldehyde, just as one would for scanning electron microscopy. The time can be extended further by preparing the stained filters, mounting them on slides in immersion oil, and storing them in the refrigerator.

We have also worked with Karen Porter on the development of DAPI staining for epifluorescence counting (Porter and Feig 1980). Although DAPI staining 
has some advantages, we will not switch to it as a routine counting procedure unless data we are now collecting indicate that there is a significant difference in total counts. One of the minor disadvantages of DAPI staining is the necessity to prepare stained filters immediately at sea. The filters must then be kept cold until they are returned to the laboratory and counted.

\subsection{Utilization of Dissolved Substrates by Bacteria in Gulf Stream Intrusions}

To evaluate microbial responses to intrusions it is necessary to develop methods and criteria of activity appropriate for the populations in question. We have found that specific (per cell) uptake rales (Wright 1978) present a problem when cell volumes vary over two orders of magnitude, as they do in oceanic bacteria. Using dissolved adenosine triphosphate (DATP) labeled with ${ }^{32} \mathrm{P}$ as a tracer, we measured uptake of naturally occurring DATP by natural populations of free and attached bacteria in a Gulf Stream intrusion and in adjacent Gulf Stream and continental shelf water. Free bacteria in the ocean, including the outer continental shelf are, with rare exceptions, less than 0.5 micrometers in size, while attached bacteria are usually greater than one micrometer in size. The greater size is generally taken to indicate greater metabolic activity and active growth on the part of attached bacteria.

DATP is a convenient naturally occurring organic compound to study, because a good analytical method exists (Azam and Hodson 1977), and 32p-1abe1ed ATP can be used as a sensitive tracer. Hodson and Azam (1977) have shown that DATP is biologically active: its is readily taken up by bacteria. Uptake by free and attached bacteria can be distinguished in ocean water by counting ${ }^{32} \mathrm{P}$ activity retained on 0.2 and $0.6 \mu \mathrm{m}$ Nuclepore filters. Aliquots from the same water samples were also preserved in cold glutaraldehyde for counting free and attached bacteria by acridine orange fluorescence.

Specific uptake of DATP was highly correlated with ambient DATP concentration. Specific uptake of DATP by large, attached bacteria was 4-430 times that of small, free-living bacteria. Specific uptake by both free and attached bacteria increased up to 200 times within 24 hours of the arrival of an intrusion on the continental shelf. Uptake rates of free and attached bacteria are significantly correlated $\left(r^{2}=0.8\right)$, suggesting that both are. dissolved substrates and both are stimulated by intrusion events. 
While on a per-cell basis the rate of uptake of DATP by attached bacteria was 66 times higher than that by free bacteria, the uptake per unit of biomass was essentially the same for both populations; because attached bacteria have approximately 40 times the volume of free bacteria. Therefore, on the basis of equal units of biomass, attached bacteria do not appear to be more active than free minibacteria. Of course, this may be because a significant fraction of the population of free bacteria is inactive. However, when bacterial populations are widely divergent in size, as are the free and attached bacteria of the ocean, the best basis of comparison appears to be activity per unit biomass rather than per cell.

A more complete account of this is in the manuscript by Hodson, Maccubbin and Pomeroy (in press) which is a part of this report.

3.3. Interactions of populations of Free Bacteria, Attached Bacteria, and Aggregates

The work of Hodson et al. (in press) showed that both free and attached bacteria respond to Gulf Stream intrusions by increasing their numbers and their uptake of dissolved substrates. In a further examination of the interactions of these populations we examined the relationship of bacteria, phytoplankton, and chroococcoid cyanobacteria to the abundance of flocculent aggregates. The abundance of flocs varies greatly, sometimes dominating the population of particulate matter and sometimes being a comparatively rare component. In general, dense populations of flocs are associated with intrusions of Gulf Stream water (but are in surface water as well as in the subsurface intrusion) and with biologically productive nearshore fronts.

A set of 45 samples from all parts of the continental shelf was examined. Each sample was counted with acridine orange epifluorescence for free and attached bacteria, phytoplankton, chroococcoid cyanobacteria, and flocculent aggregates. In each case a sample was categorized as having a dense flocculent background or not having one. Because a dense population of flocs may obscure free bacteria, this in itself might tend to reduce the count of free bacteria in the presence of dense flocs. Of the 45 samples examined, 29 had a dense flocculent background and 16 did not. Using the Wilcoxon two-sample test, the following parameters were tested with respect to the two categories of samples. 
1. Number of free bacteria per $\mathrm{ml}$.

2. Variance of the free bacteria counts as a per cent of the mean.

3. Per cent of flocs with attached bacteria.

4. Mean number of attached bacteria per floc.

5. Per cent of time viable phytoplankton occur with flocs.

6. Per cent of time flocs occur with viable phytoplankton.

7. Ratio of viable phytoplankton to flocs.

8. Per cent of time cyanobacteria occur with flocs.

9. Per cent of time flocs occur with cyanobacteria.

10. Ratio of cyanobacteria to flocs.

11. Floc/free bacteria ratio.

12. Viable phytoplankton/free bacteria ratio.

The number of free bacteria was significantly greater at the $99 \%$ confidence level for samples with a dense flocculent background, in spite of the likely possibility that some free bacteria were obscured by the flocs. The per cent of flocs with attached bacteria on them was significantly greater at the $95 \%$ confidence level in samples with a dense flocculent background. Also, the per cent of flocs that occur with cyanobacteria is significantly greater at the $95 \%$ confidence level in samples with a dense flocculent background. Particularly when viewed in the light of the findings of Hodson et al., these additional findings suggest that dense populations of flocculent aggregates are a phenomenon of productive conditions where bacterial numbers have increased. There is no substantial agreement in the literature on the nature and origin of flocculent aggregates. Over the years they have been postulated to be condensations of dissolved organic matter, extracellular products of bacteria, and fecal matter. Very likely they are all of the above in various proportions. Their presence in situations of high productivity and their relative absence elsewhere suggests that they have a comparativcly short residence time in the water, either because they aggregate further and sink or because they are degraded by bactcria, Again, these maynnt. he mutually exclusive fates, and both fates provide flocculent aggregates with apotential role in the food web of the continental shelf. These potential roles are explored in a different manner in the simulation model of the food web (section 3.5 ). 


\subsection{Production of Fecal Aggregates by Zooplankton}

A novel finding in the course of our work on microbial processes in continental shelf water was that some of the flocculent organic aggregates which are a common feature of the seston of productive surface water are fecal. Some of them are identifiable as the fecal ribbons of pelagic tunicates (salps, doliolids, and appendicularians) which have broken up in the water (Pomeroy and Deibel 1980). Our assertions about finding this fecal material in the water in small $(50 \mu \mathrm{m})$ fragments has been contested by some workers on the grounds that salp feces are found in sediment traps, and some other studies of salp feces have shown that they sink rapidly. What these investigators do not seem to appreciate is that pelagic tunicates do not produce fecal pellets but a fecal ribbon which break away. Within the ribbon are boluses of material which do remain intact and do sink rapidly. This is the material found in sediment traps and, because it is big enough to see with the unaided eye, it is what other workers have studied exclusively. These large boluses are only a part of the fecal matter however. Studies of the respiratory rate of fecal material (Pomeroy, in prep.) and of the uptake of adenine by the material ( $R$. Hanson, pers. com.) show that there is more activity in the small fragments which remain in suspension than in the large boluses which sink out of the water column. Since the fragments are seen only by oil immersion microscopy, they have been missed by other workers. A second publication describing this is in preparation.

Probably a number of other zooplankton contribute to the fecal aggregate population in the sestion, including the smaller larval stages of copepods (Paffenhofer and Knowles 1979, Klinck et al. in press). We find very dense populations of what appear to be fecal aggregates in the nearshore zone where pelagic tunicates do not live. These may be benthic or may be produced by meroplankton. A proposal to continue worn on aggregates has been submitted.to the National Science Foundation. It is not our intention to continue along this line under this contract.

\subsection{A Simulation Model of the Shelf Ecosystem}

In 1978 a conceptual model of the detritus food web on a continental shelf subject ot intrusions of nutrient-rich water was developed in connection with this contract (Pomeroy 1979). The conceptual model demonstrated that, using recent estimates of gross growth efficiency of oceanic organisms, it was 
possible to have production of higher trophic levels, including fishes, while much of th energy of primary production was channelled through a detrital food web. This was in sharp contrast to the North Sea model of Steele (1974) in which all production was directed through a short, linear chain of grazing and predation, with fecal pellets going quantitatively to the benthos. The latter was not based on observed fate of fecal pellets but rather on the necessity to provide a sufficient flux of energy to the benthos in the model to support a reasonable production of demersal fishes. Pomeroy's continental shelf model demonstrated that it is possible to support fishes, both demersal and pelagic, without drastic and unrealistic assumptions about transfer of fecal pellets to the benthos, and indeed without such unrealistic assumptions about the flux of energy through a short, linear food chain, in which copepods eat $100 \%$ of the phytoplankton production. Not all of phytoplankton production is available to copepods. Much of it is rather small for them. On the other hand, Steele's model clearly demonstrated that the so-called ecological efficiency of $10 \%$ per trophic level cannot work in the real world, even if the world is constrained to clear-cut trophic levels, as was Steele's model. In the real marine environment trophic levels are blurred by bacteria, mucus net feeders, protozoans, and other omnivores.

After the crude demonstration that a model could be constructed which would produce fishe through various detrital food webs (Pomeroy 1979), J.E. Hagner was supported through this contract to develp a simulation model of such a food web. $\because$ A 17-compartment model was developed (Figure 19) which has a number of unusual features. Phytoplankton are divided into two size groups. Phytoplankton produces dissolved as well as particulate organic matter. Some of the former becomes detritus directly. There are three bacterial populations: free, attached, and benthic. There are four zooplankton populations: grazers, carnivores, mucus-net feeders, and Protozoa. This model provides for the possibility of many alternative pathways for energy and materials between primaryproducers and terminal consumers (benthic and demersal tishes, other carnivores, and benthic invertebrates). The proposition is that indeed the pathways probably do vary with the circumstances. For example phytoplankton blooms are situations in which much of the primary production is not being grazed and is going to detritus production.

Hagner develped a model along the lines of those developed for other ecosystems by Wiegert (1975; 1979a; 1979b; Wiegert and Wetze1 1979; Wiegert et 


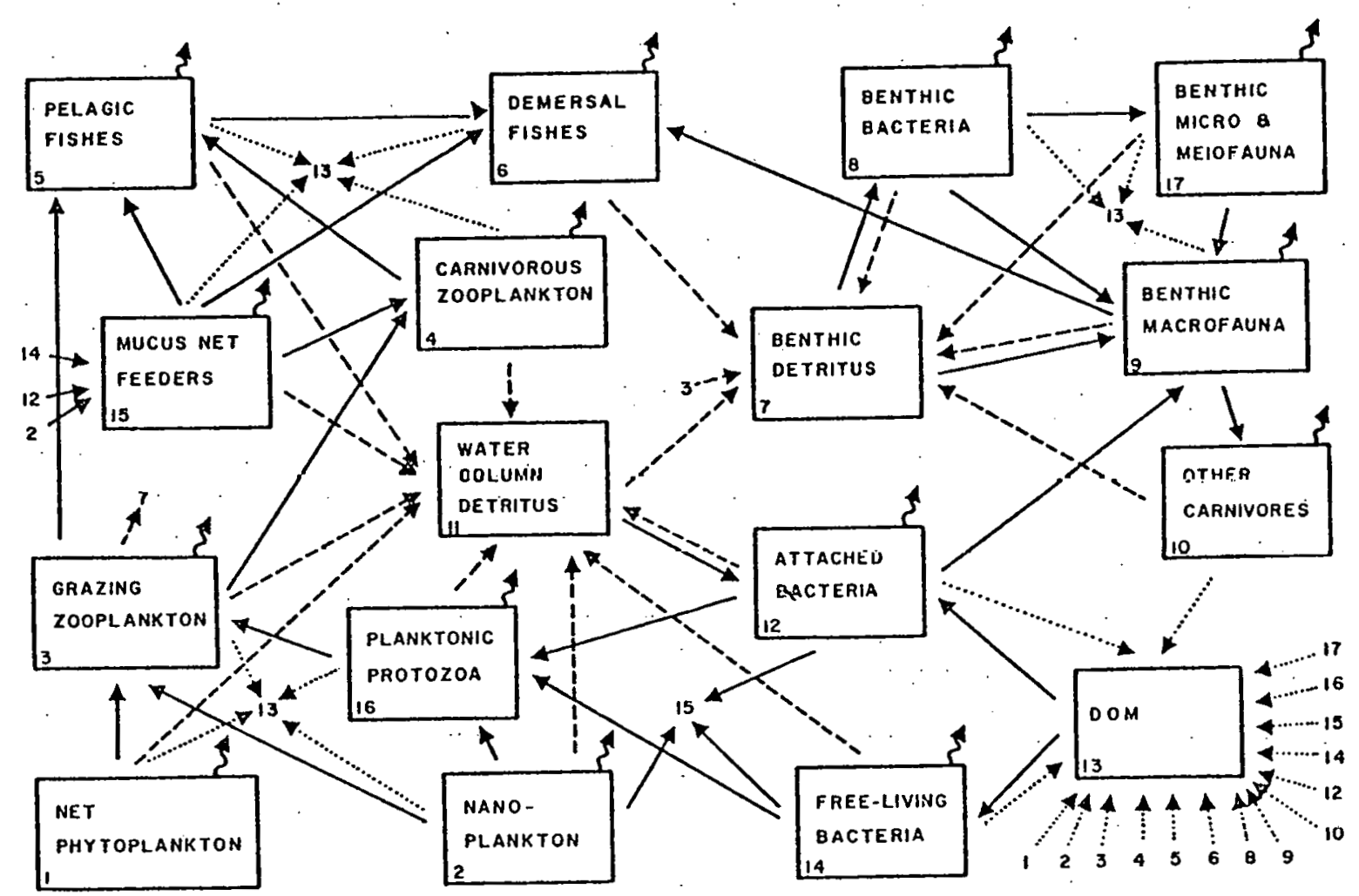

Figure 19. Simulation model of the flux of energy through continental shelf food webs. Continuous lines $=$ trophic fluxes. Dotted lines $=$ dissolved fluxes. Broken lines $=$.detrital fluxes. Wavy lines $=$ respiratory fluxes. Arrows to or from a number are additional fluxes to the compartment numbered.

al. 1975). Non-linear equations describe growth, assimilation, mortality, refuge levels, upper population limits, and other known parameters of organisms. The groups thus described are trophic groups of similar species, not individual species populations. We are postulating that ecosystem function will be similar in the presence of certain trophic groups, regardless of the species that predominate at any time. The models thus are intended to simulate ecosystem function, not species population dynamics.

There are several subsets within the model which can be varied individually to explore their effect on the entire model. There is a pelagic subset which is very similar to Steele's (1974), except for the division of phytoplankton into two ratagories based in size (and the properties which go with 
size, such as $K_{s}$ and $r$ ). There is benthic subset which includes benthic bacteria, benthic detritus, mëiofauna, macrofauna, predators, and demersal fishes (Figure 20). There is a detritus subset (Figure 21) and a dissolved organic matter subset (Figure 22). By varying these sets, as well as components of them, it is possible to simulate many situations which have been documented in the literature and others which are postulated. Assimilation efficiency can be set to correspond with values in the recent literature or the model can seek efficiencies which lead to a stable system.

Unfortunately, Hagner had to leave the work before it was completed, and. after a lapse of about a year the work was taken up again by Michael Pace, who is now completing work with the first-generation model. It is an energy model with nitrogen forcing on primary production. Productivity is adjusted to reasonable levels by varying the number or intensity of intrusions of nitrate -rich water. The model is space-averaged and does not simulate the two-layered

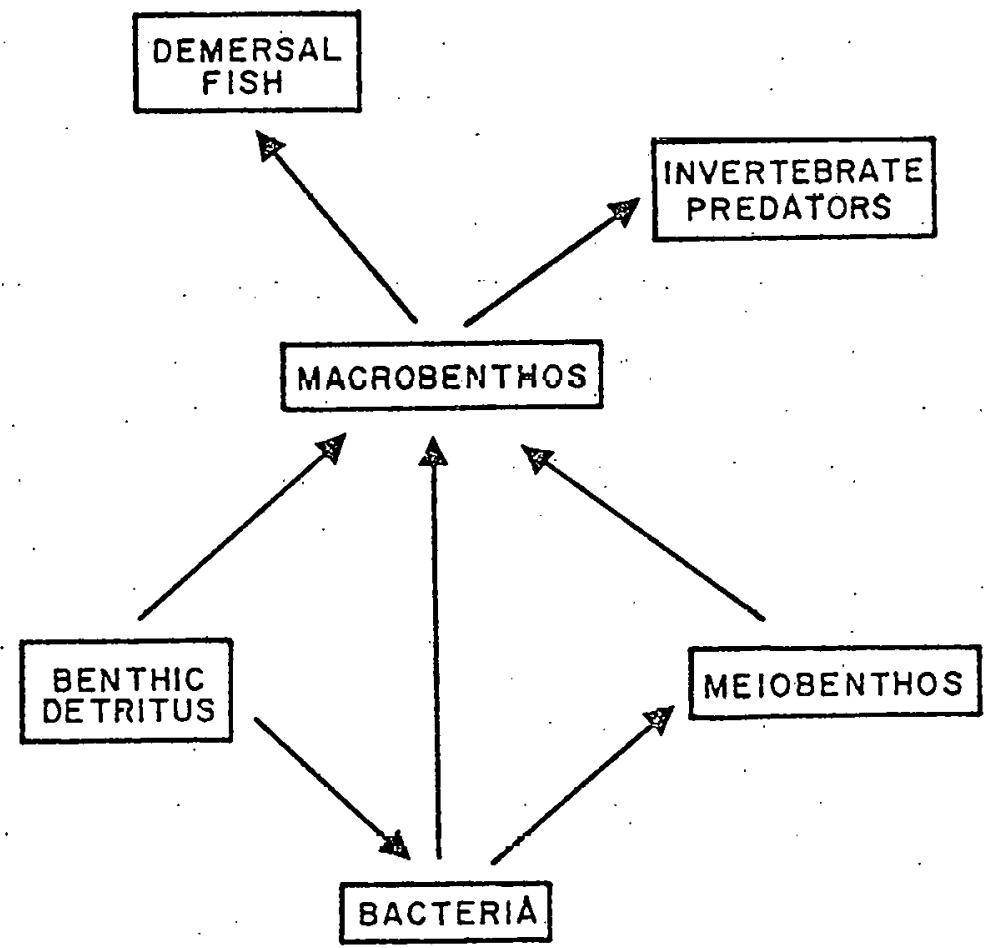

Figure 20. Subset of benthic energy fluxes on the 17-compartment model of energy flux on continental shelves. 


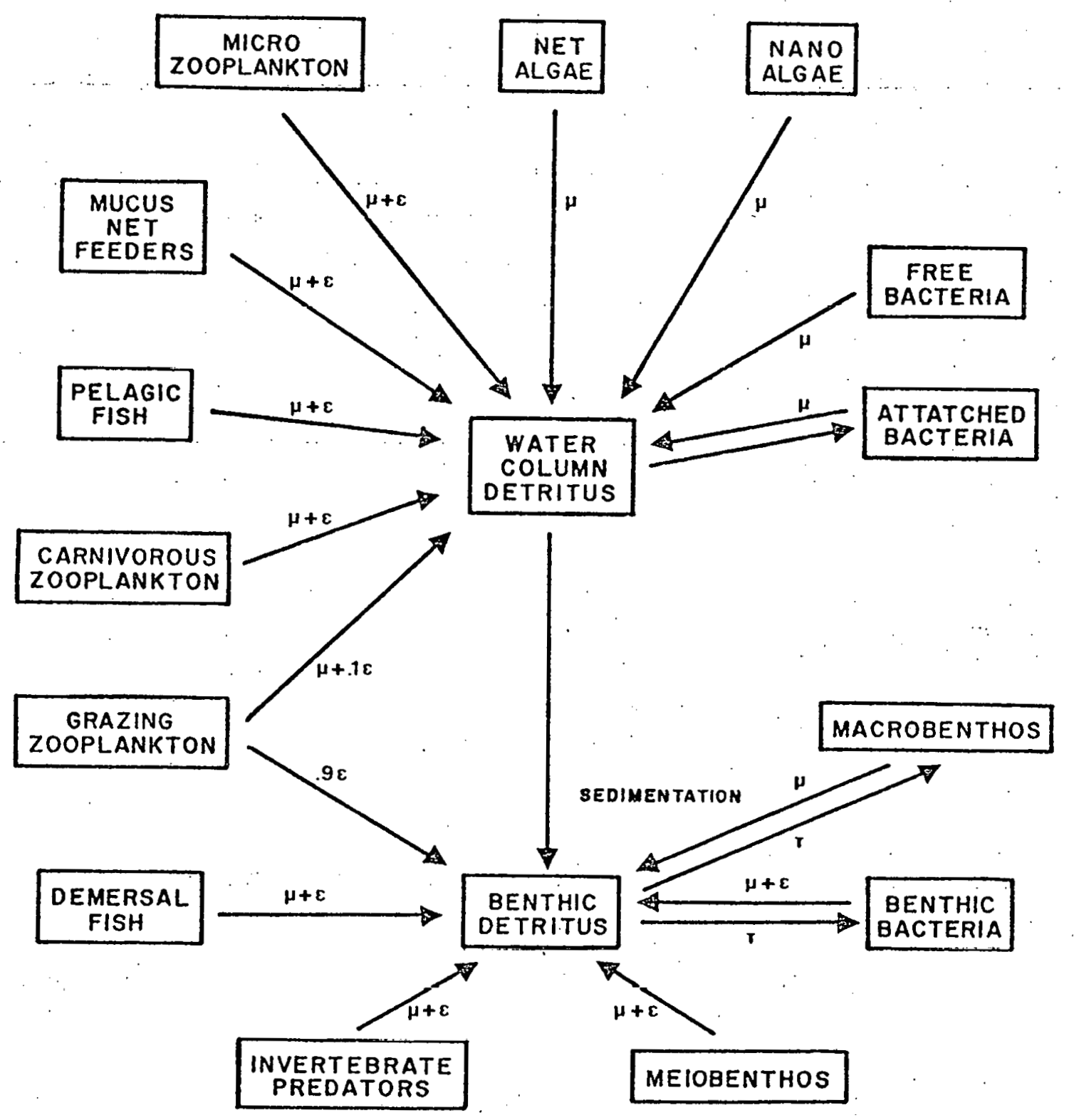

Figure 21. Pathways of energy to and from detritus in the simulation model of the flux of energy in a continental shelf ecosystem. 
Table 5. Simulated zooplankton production, $\mathrm{K} \mathrm{Cal} \mathrm{m}^{-2} \mathrm{yr}^{-1}$ in a mixed detritus and phytoplankton based food web.

A. Four pulses of nitrogen at regular intervals. B. Short pulses of nitrogen at 20 -day intervals:

A

Ingestion

Assimilation

Respiration

Excretion: loss of DOC

Physiological mortality

Predatory mortality

Egestion

Gross growth efficiency

Production

B

Ingestion

Assimilation

Respiration

Excretion

Physiological mortality

Predatory mortality

Egestion

Gross growth efficiency

Production grazers

5.61

393

181.

82

41

96

168

0.24

137

633

443

178

84

42

137

190

0.28

180 mucus-net. Protozoa Total feeders

4.04

393

1358

263

275

931

117

117

415

61

70

212

30

78

58

85

230

142

118

428

0.22

0.30

0.25

89

118

343

422

488

1543

274

342

1059

115

149

442

60

96

240

30

10

82

69

87

294

147

147

484

0.24

0.20

0.24

100

97

376 
condition of an intrusion on the outer continental shelf. This is a potential refinement for a second generation model. There are no lags in responses of populations in the present model, so there is some foreshortening of time of the responses to the pulses of nitrogen.

By varying the nitrogen forcing, the model can be made to simulate various coastal upwelling situations, as well as the spring bloom conditions of temperate oceans and epicontinental seas (Table 4 and Figure 24). At this level of aggregation. there is really. nothing unique about a particular marine ecosystem, so long as it is at least 50 meters deep. The model is very. stable, as indicated by the means of each of five years of simulation, and this stability carries on through the food web.

In a preliminary run of the simulation, secondary production is divided between various zooplankton groups in what is, so far as we know, a realistic way. We cannot validate the relatively large production of Protozoa at this time, either from our own work or from the literature, although there are indications that it probably is realistic. Gross growth efficiencies are similar to those in the recent literature (Pomeroy 1979; Mills 1980; Banse and Mosher 1980). Secondary production of bacteria is nearly as high as that of zooplankton (Tables 6 and 7). Although this would be missed by a highly condensed model such as Steele's, probably it is a realistic representation of the partitioning of energy fluxes in a planktonic ecosystem. The recent estimates of bacterial production using. tritiated thymidine (Fuhrman and Azam 1980) tend to support it. Various levels of production in the simulation model compare favorably with data from continental shelf ecosystems (Table 8). When run as an intrusion model, the simulation yields of demersal fishes are low. Everything we know about the outer continental shelf of the southeastern U.S. supports this (Tenore et al. 1978). The brief nature of intrusions is not conducive to development of demersal fish populations, and except for some small populations associated with ledges and rock outcrops, there is little demersal fish production, so far as we know at present.

The simulation model of the continental shelf ecosystem will serve several functions. It provides a richer simulation of the pelagic food web than most extant models, allowing us to explore the potential fluxes of energy and materials through detritus, bacteria, non-crustacean zooplankton, and even dissolved materials. This in turn serves as a heueristic device to show us the populations and processes not well represented in the presetn DOE research 


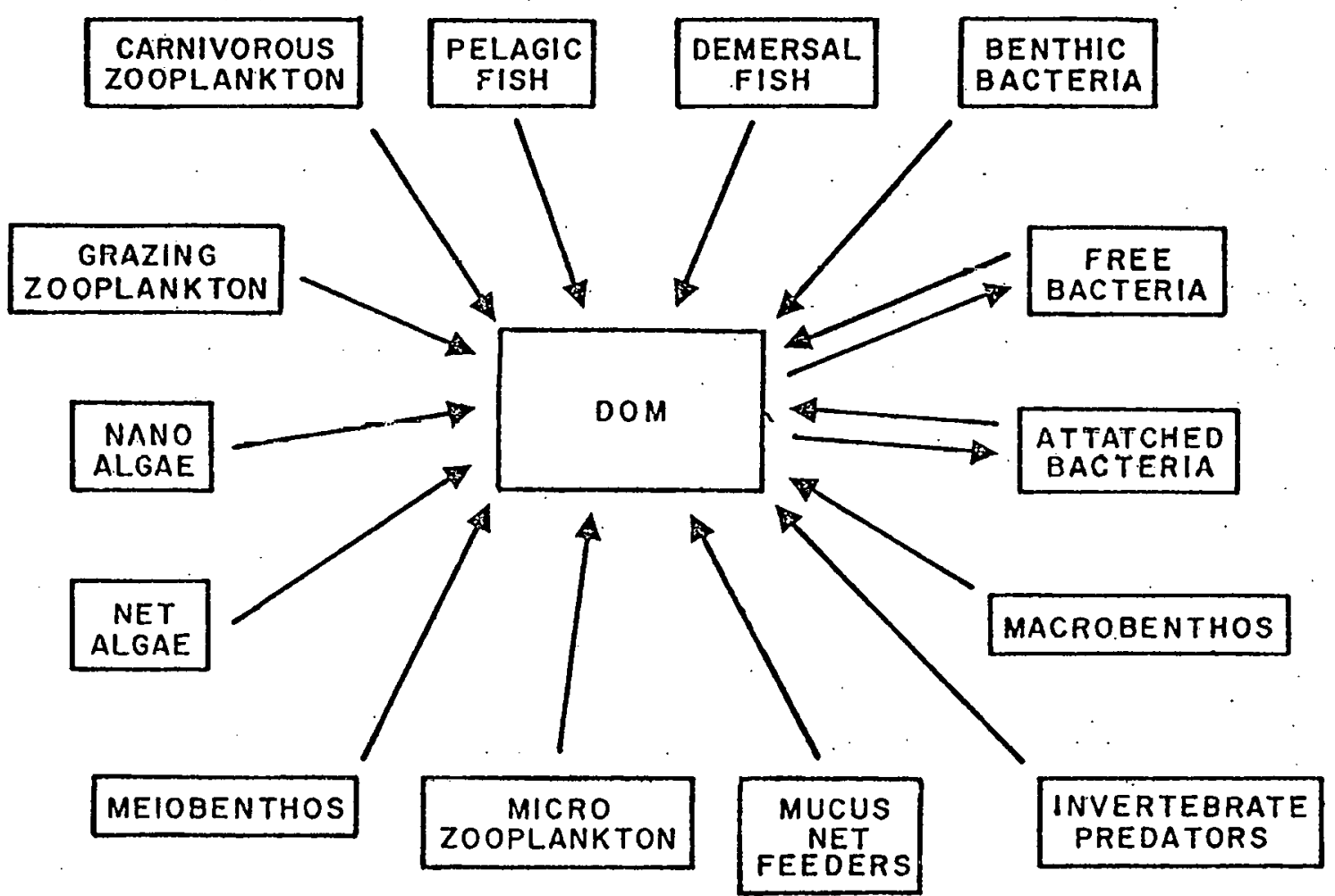

Figure 22. Fluxes of dissolved organic carbon in the 17-compartment simulation model of the flux of energy through continental shelf ecosystems.

program in the southeast. Protozoa immediately appear as one such under-investigated group. The reader should, of course, be careful not to ask this model to perform simulations it was not designed to do. Response times of trophic groups may not be realistic, although they will be in relative proportion to each other. Of course, any model wuch as this suggests what is possible or impossible and does not tell us what indeed happens in the real world. Prediction is not an immediate goal of this modeling effort. 
Table 6. Simulated bacterial production, $\mathrm{K} \mathrm{Cal} \mathrm{m}^{-2} \mathrm{yr}^{-1}$ in a mixed detritus and phytoplankton based food web.

A. Four pulses of nitrogen at regular intervals. B. Short pulses of nitrogen at 20 -day intervals.

A

Ingestion

Respiration

DOM loss

Physiological mortality

Predatory mortality

Gross growth efficiency

Production

B

Ingestion

Respiration

DOM loss

Physiological mortality

Predatory mortality

Gross growth efficiency

Production
Benthic Planktonic attached free
209

99

36

10

.66

0.37

76

1347

1891

286

103

30

1470

0.79

1500

104

11

684

239

86

25

335

0.53

361

753

248

86

26

393

0.56

0.42
Tota 1

Plankton Total

893

338

122

212

61 35

402

0.49

437

\section{4}

1722
0.6
1784

2894

1004

643

356

228

125

67

37

486

0.52

0.70

523 
Table 7: A comparison of metabolic rates and production of zooplankton and bacteria in a simulated food web. which

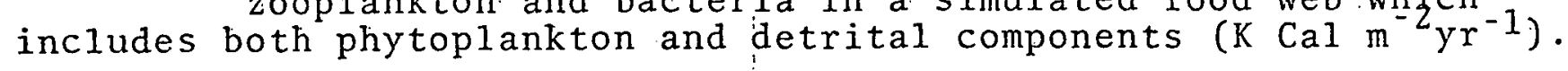

Four regular pulses of nitrogen per year

Zooplankton Bacteria

Ingestion

Respiration

Production
1358

415

343
893

338

437
Short pulses of nitrogen every 20 days

Zooplankton Bacteria

1543

442

1004

376
356

523

Table 8. A comparison of production data $\left(\mathrm{K} \mathrm{Cal} \mathrm{m}^{-2} \mathrm{yr}^{-1}\right)$ from studies of several ecosystems (from Mills 1980) with production values from a simulation model of a mixed phytoplankton and detritus food web in a continental shelf subject to periodic intrusions of nitrate-rich water.

System

$\mathrm{Net}$ Primary Production
Zooplankton $n$
Macro- Demersal benthos Fishes
Pelagic Fishes

\begin{tabular}{|c|c|c|c|c|c|}
\hline Scotian Shelf & 1160 & 89 & 35 & 4 & 4 \\
\hline Scotian Slope & 1148 & 79 & 27 & 2 & 16 \\
\hline North Sea & 1026 & 128 & $20-50$ & 3.3 & 10 \\
\hline Intrusion mode1 & 1630 & 137 & 36 & 1 & 3 \\
\hline $\begin{array}{c}\text { Spring Bloom } \\
\text { model }\end{array}$ & 1599 & 141 & 39 & 2.5 & 4.4 \\
\hline $\begin{array}{c}\text { Peru upwelling } \\
\text { model }\end{array}$ & 3715 & 701 & 141 & 1.2 & 55 \\
\hline
\end{tabular}




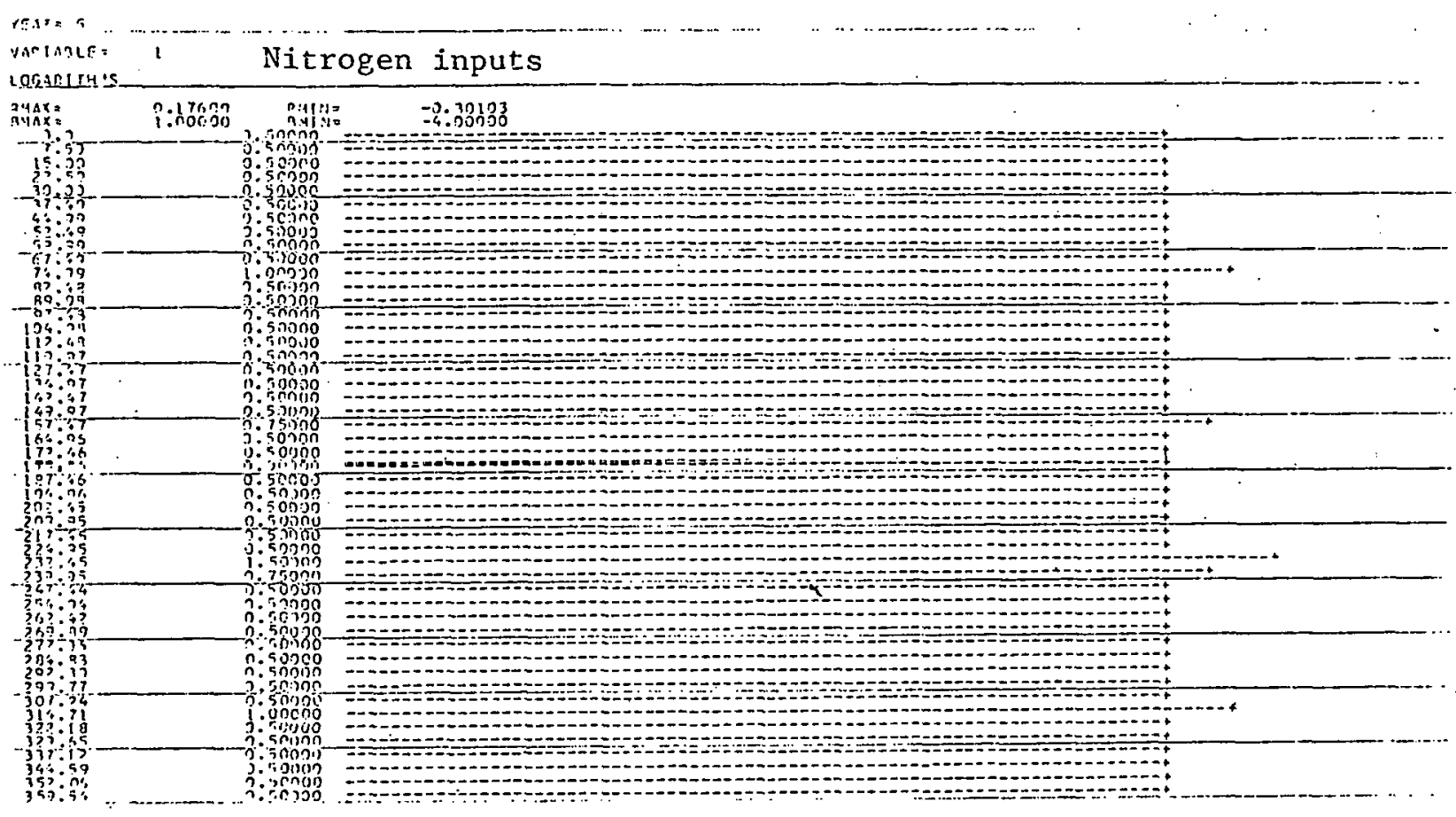

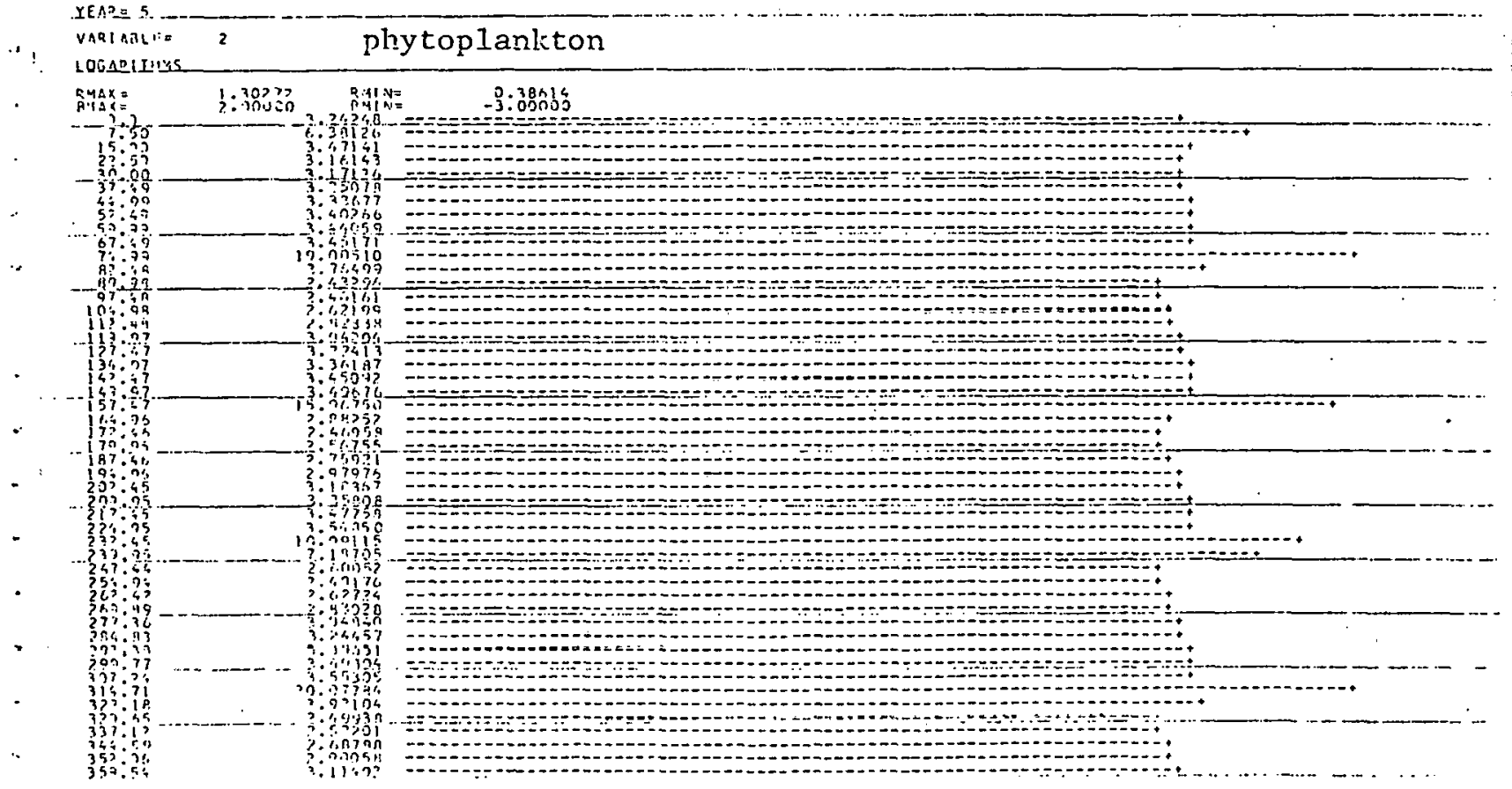

Figure 23a. Output of 5th year of simulation of four intrusions per year. 

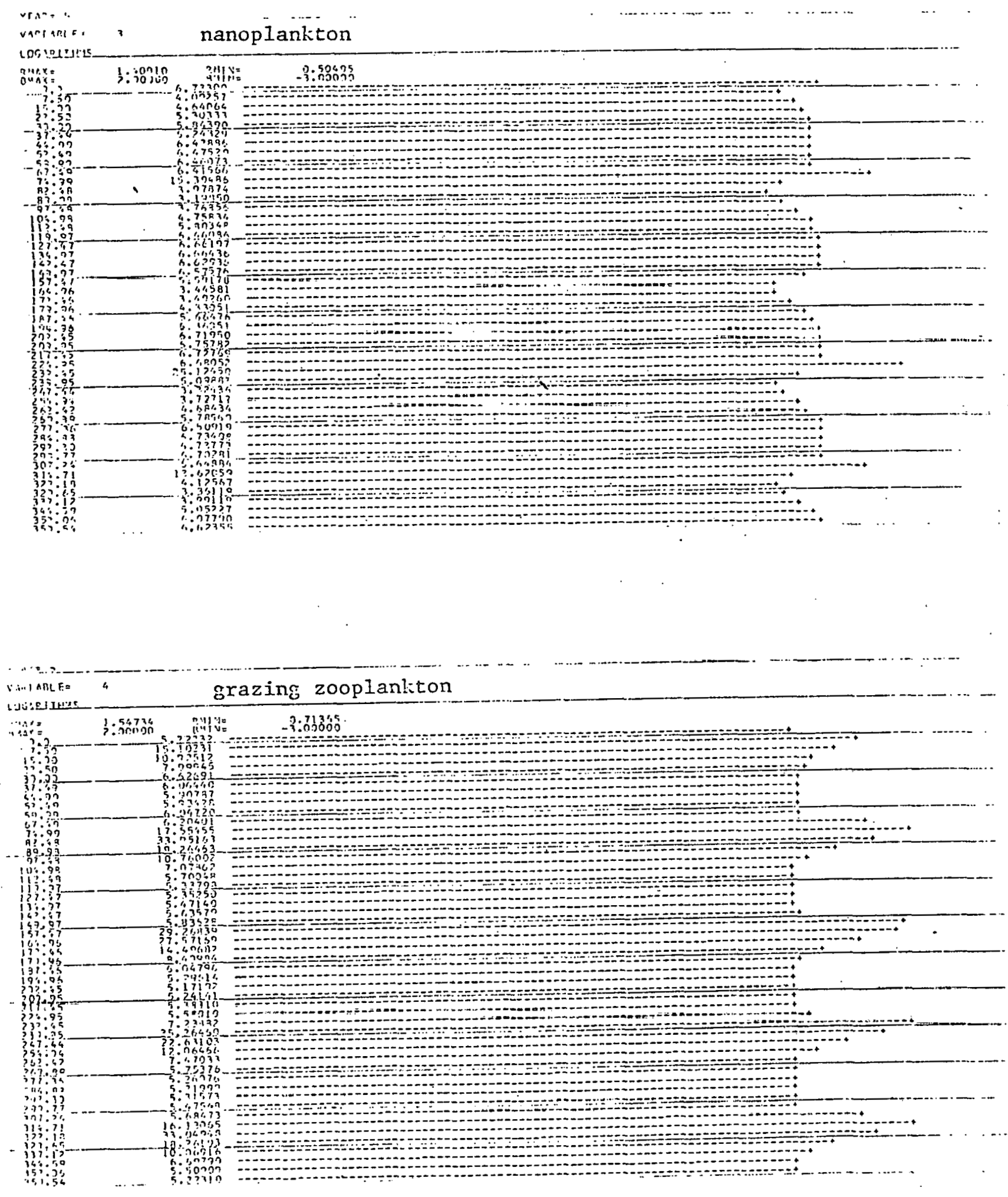

Figure 23b. Output of 5 th year of simulation of four intrusions per year. 

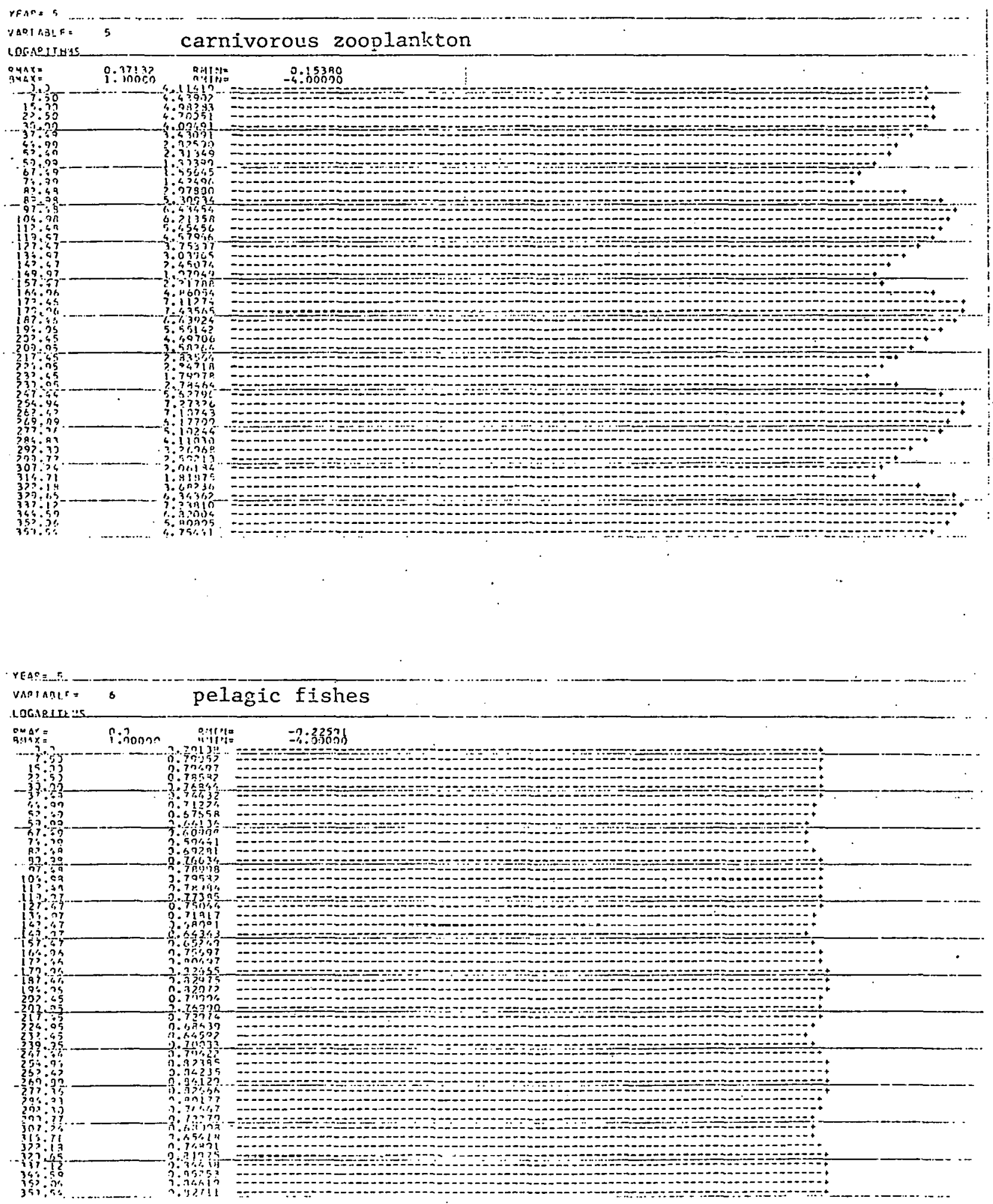

Figure 23c. Output of 5 th year of simulation of four intrusions per year. 

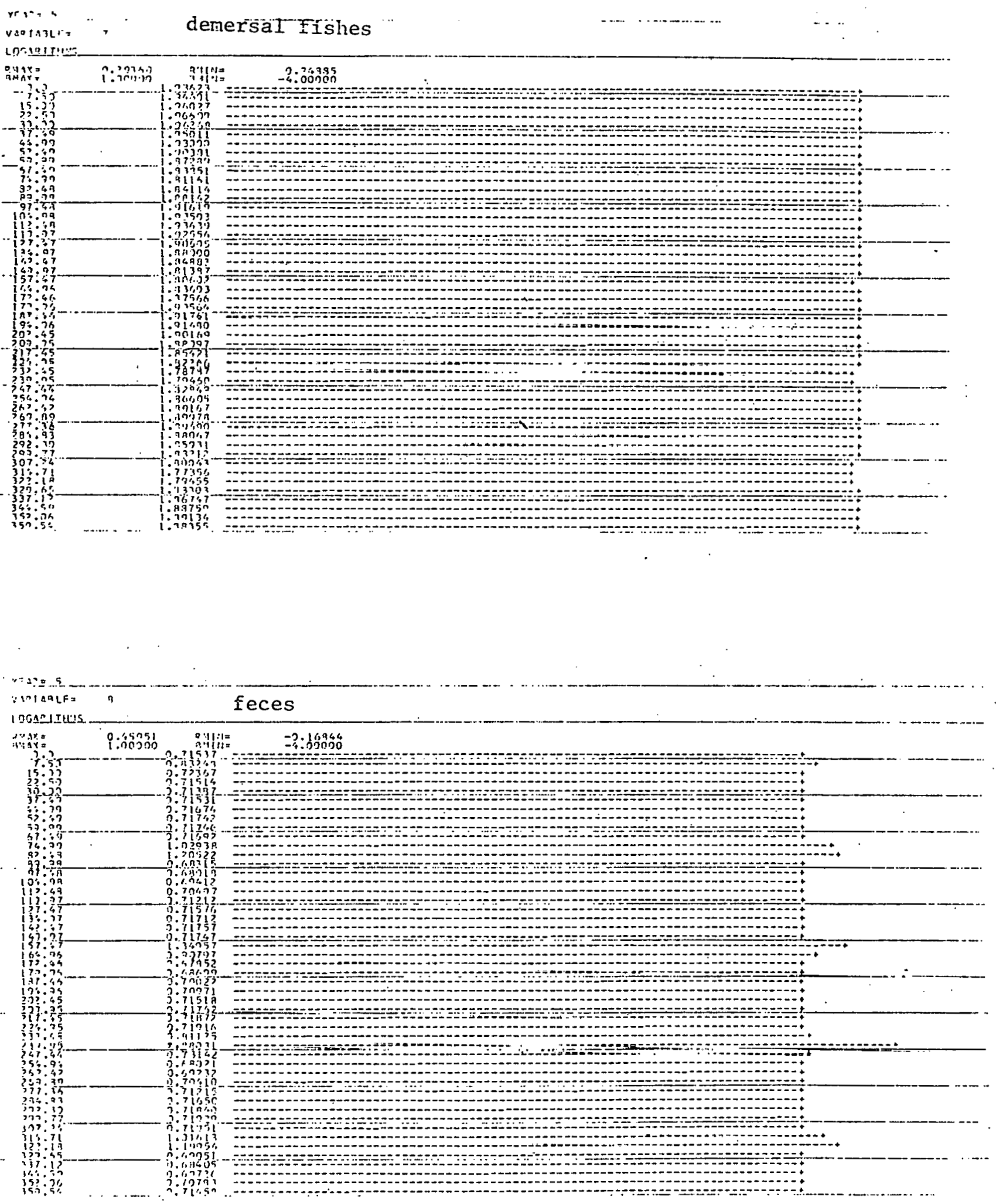

Figure 23d. Output of 5 th year of simulation of four intrusions per year. 

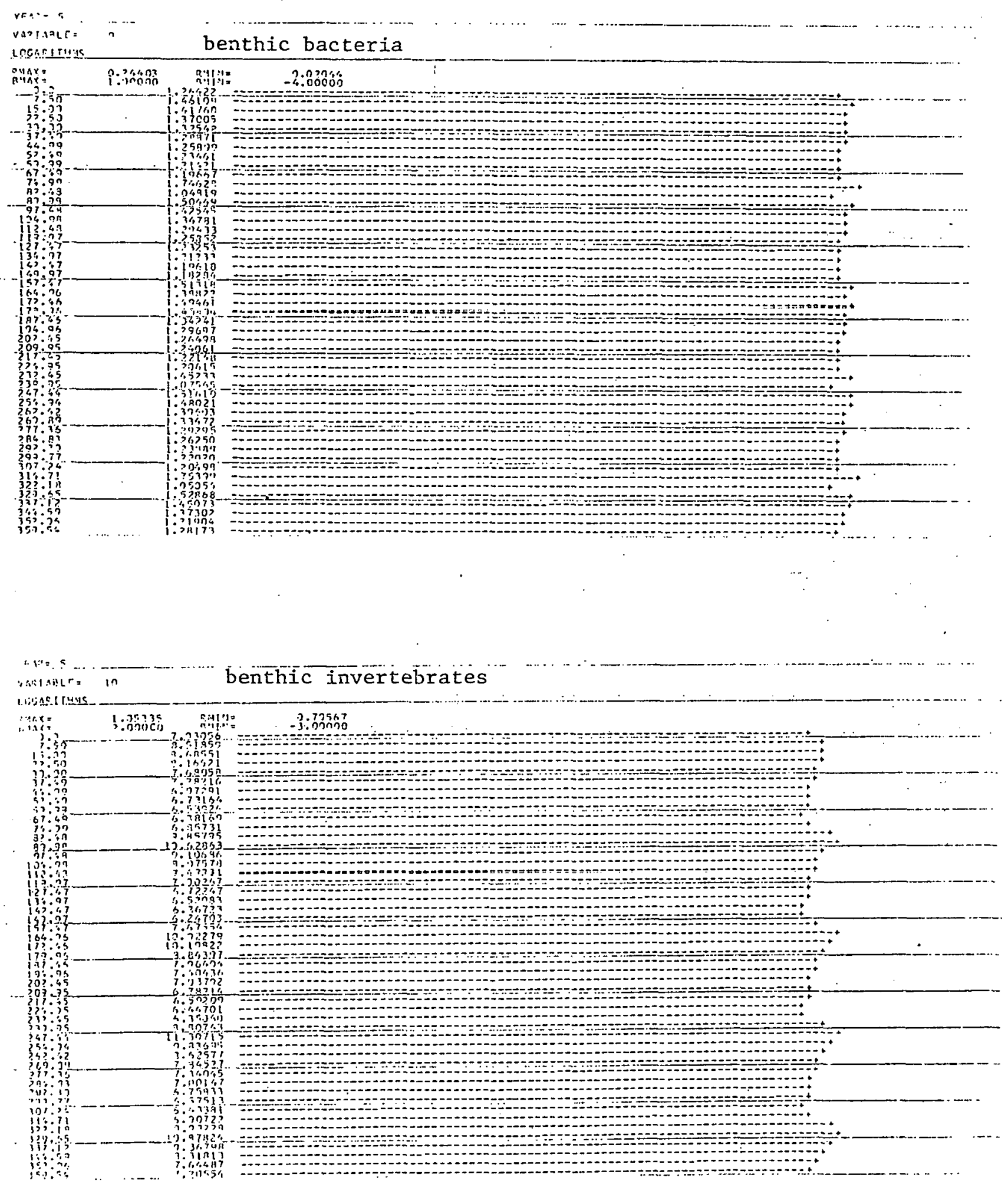

figure 23e. Output of $5 \mathrm{Lh}$ year of simulation of four intrusions per year. 

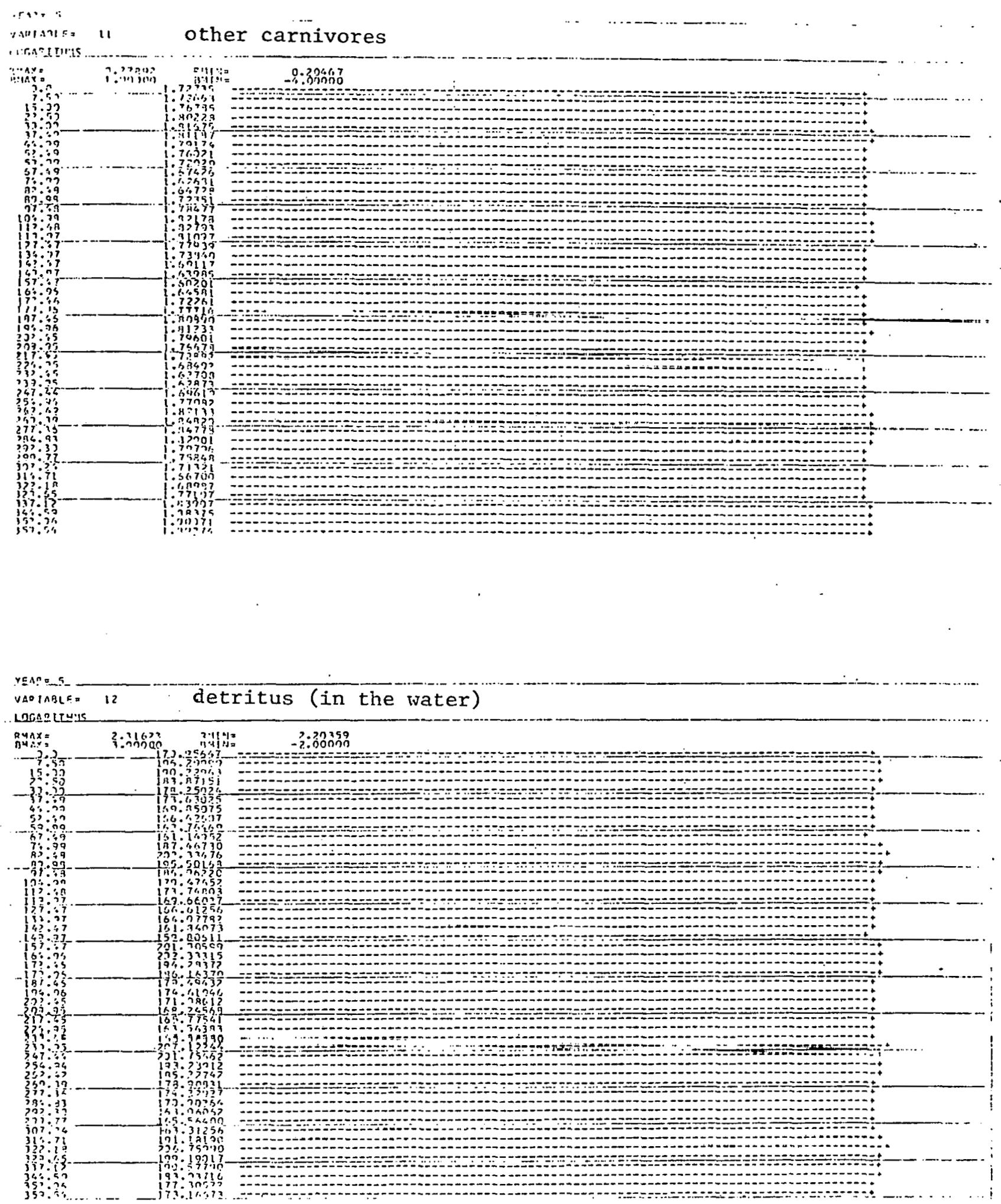

Figure 23f. Output of 5 th year of simulation of four intrusions per year. 

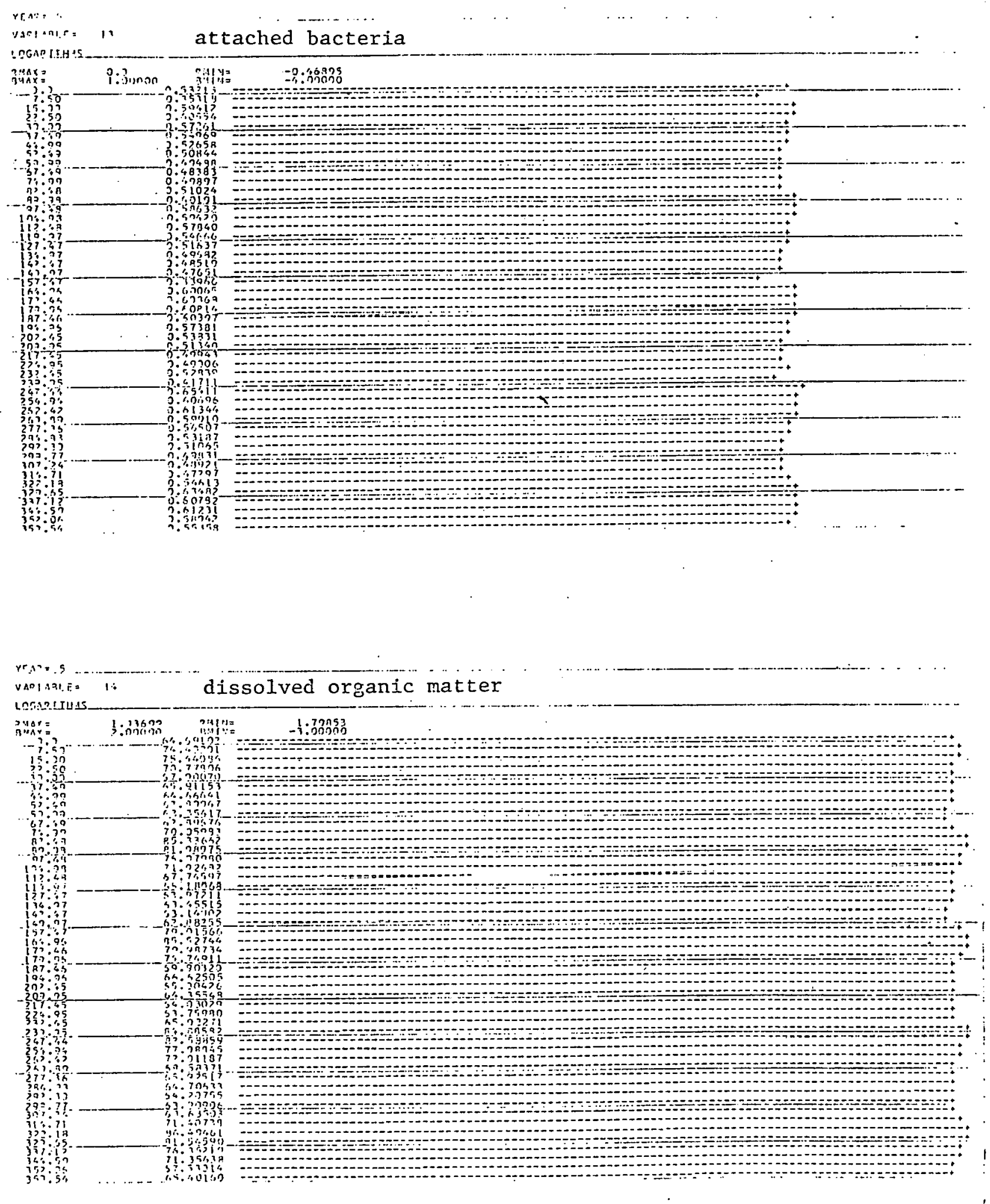

Figure 23g. Output of 5 th year of simulation of four intrusions per year. 

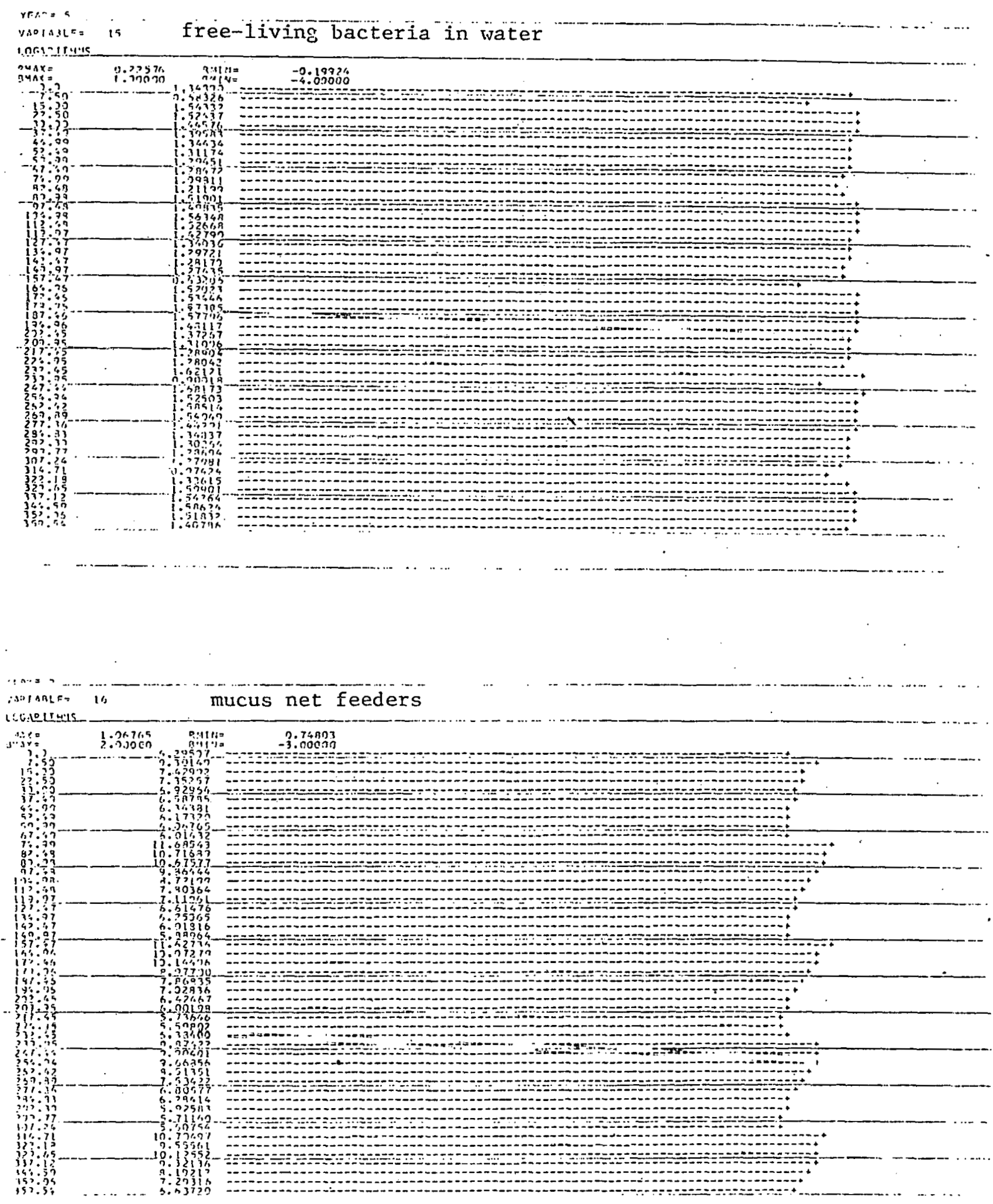

Figure 23h. Output of 5 th year of simulation of four intrusions per year. 


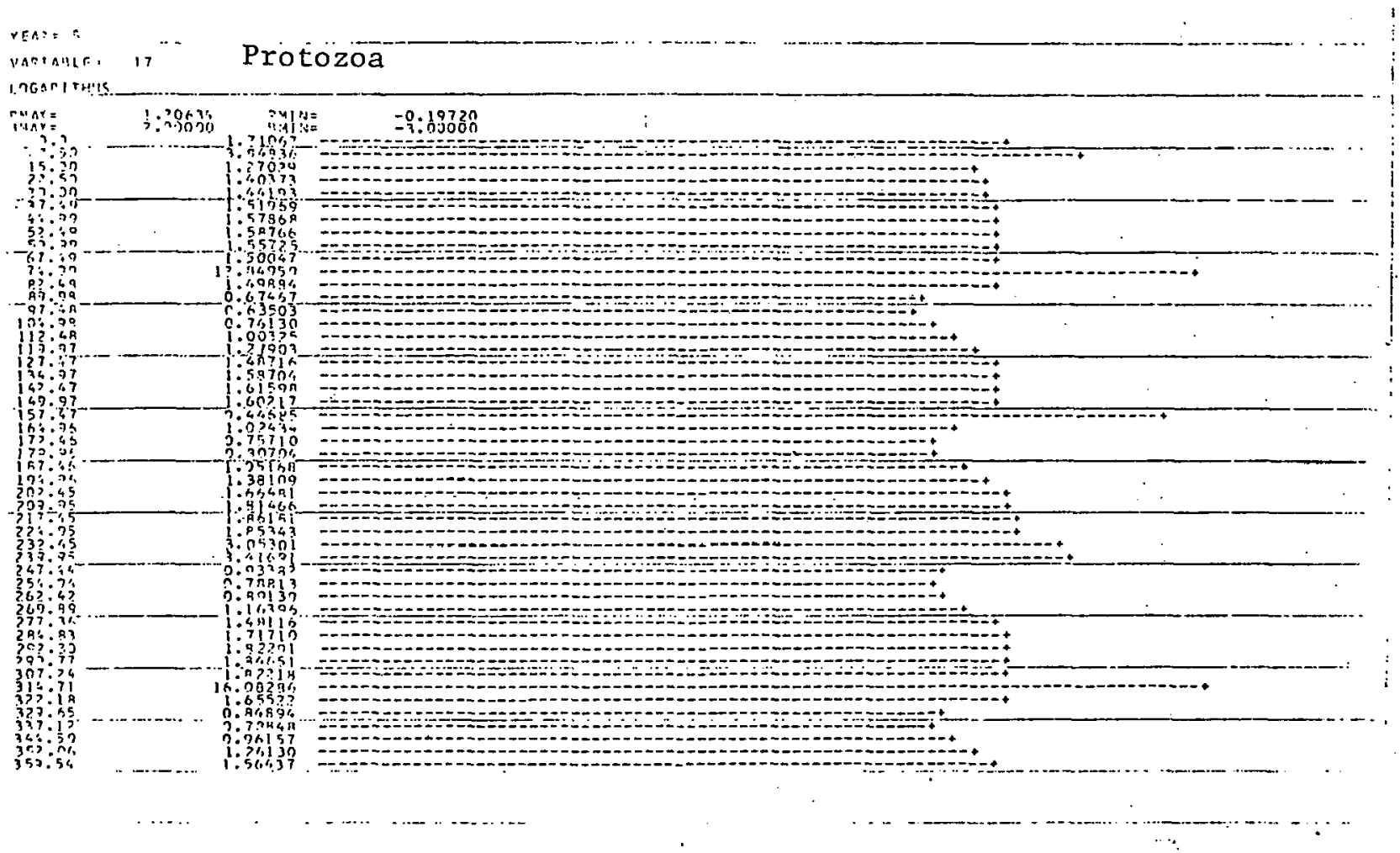

VADIAT:LF= 13 meiobenthos

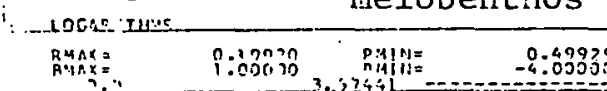

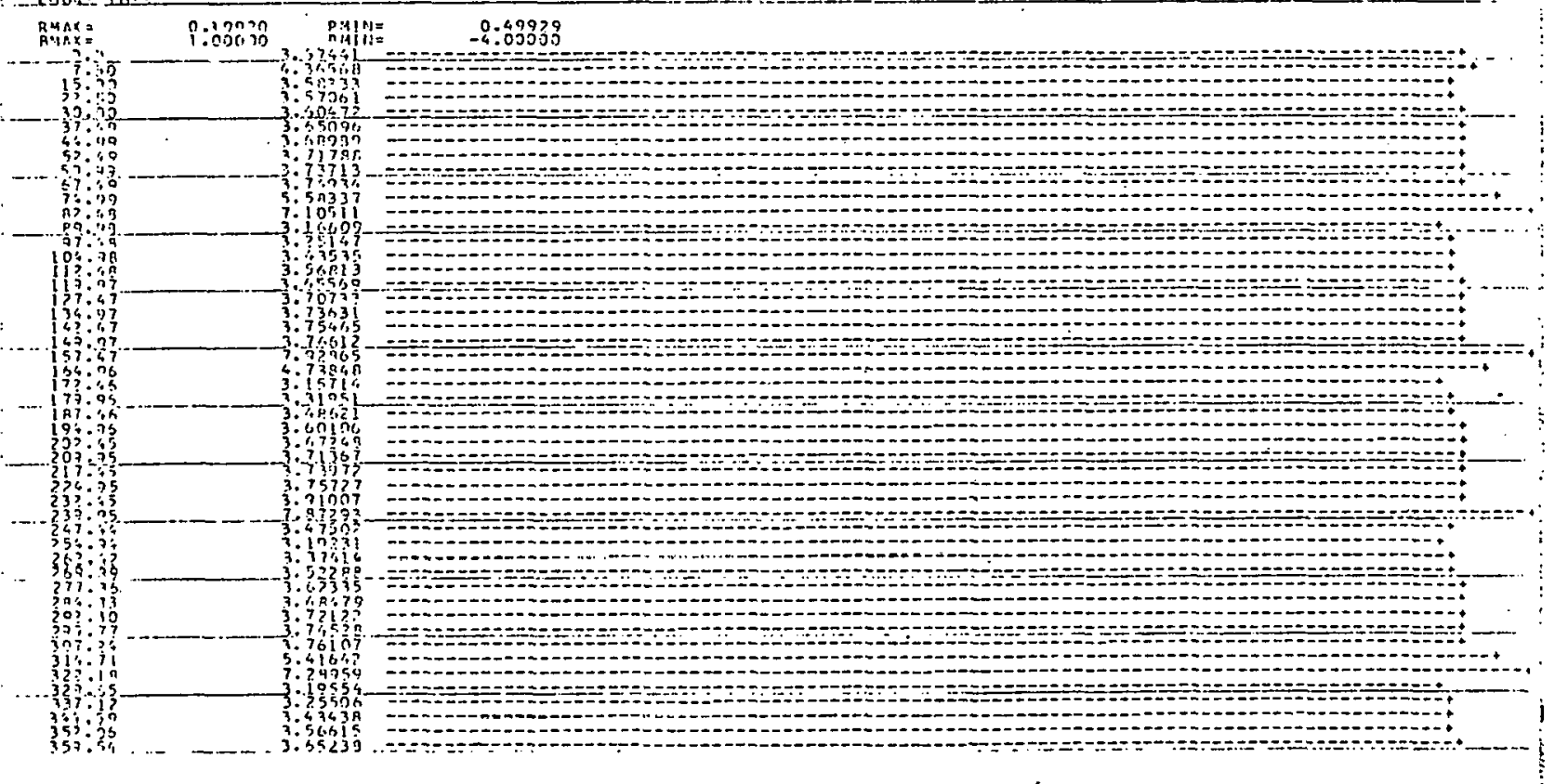

Figure 23i. Output of 5th year of simulation of four intrusions per year. 

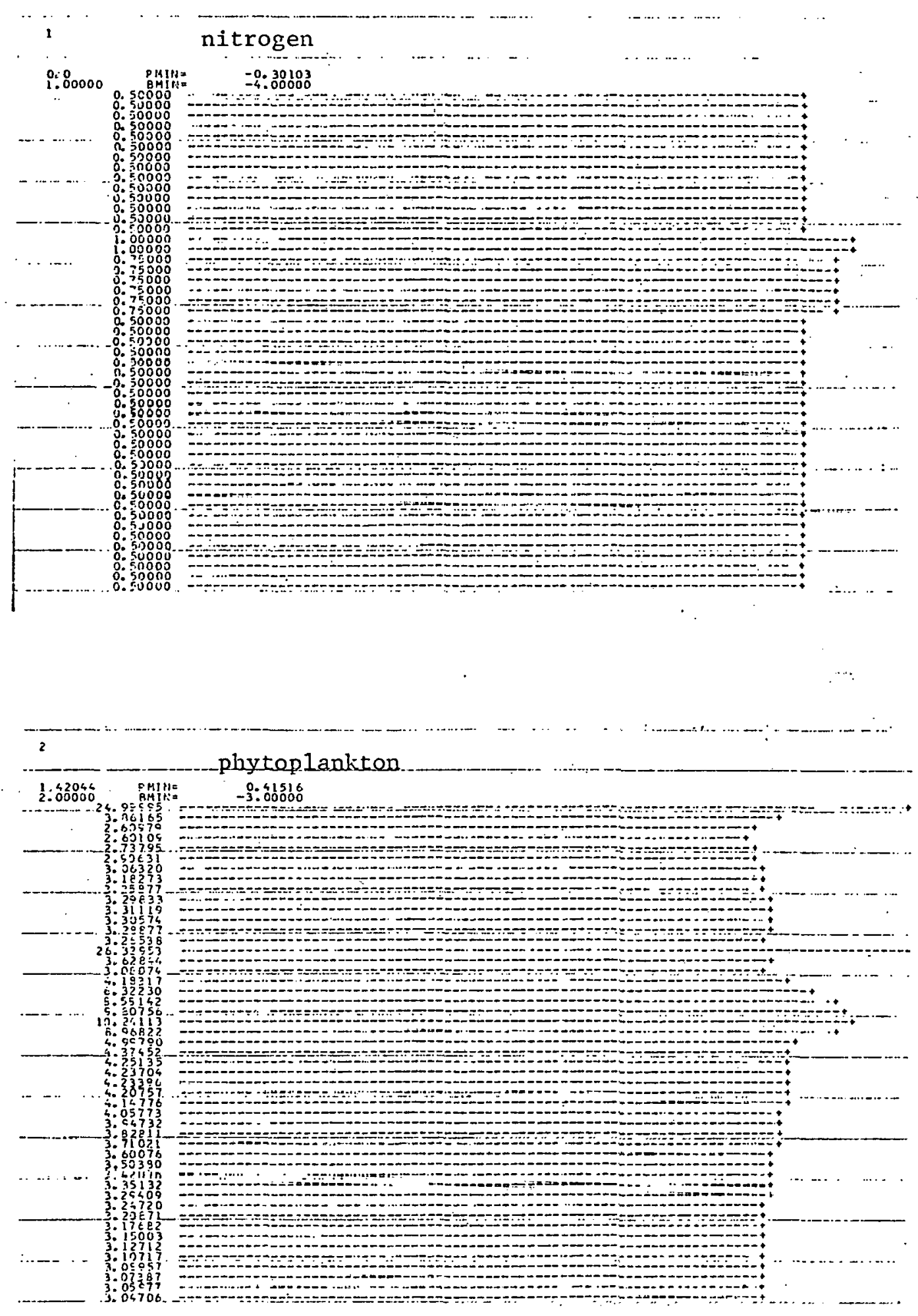

Figure 24a. First year of simulation of a temperate spring bloom. 

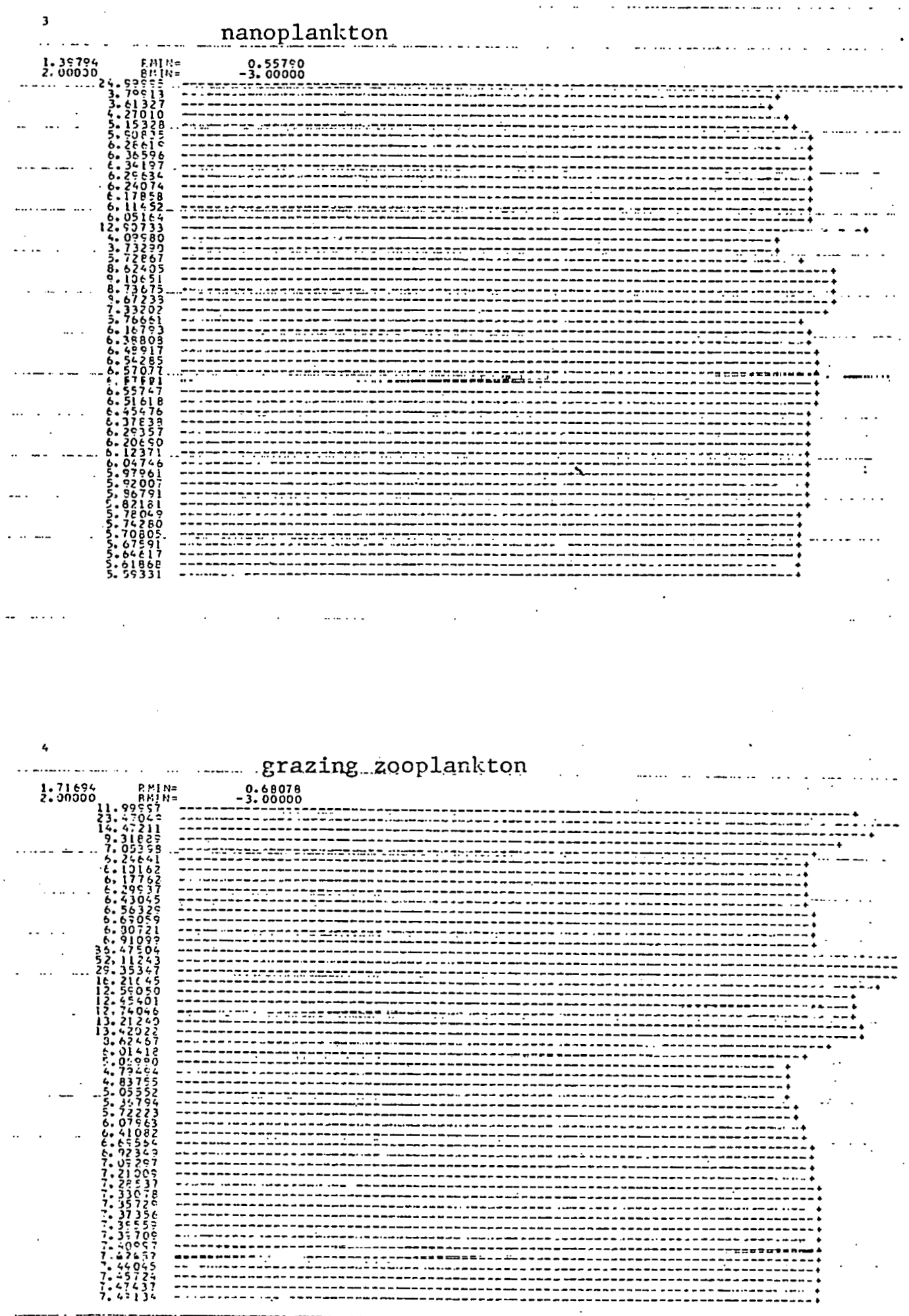

\section{....... grazing zo.zoplanktọ} 0.0 .68078 ron . -

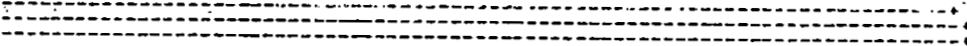
:(1)  -

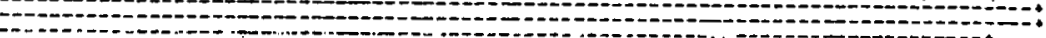
rand -

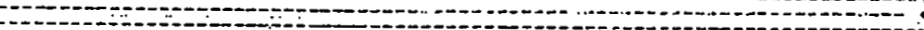
-

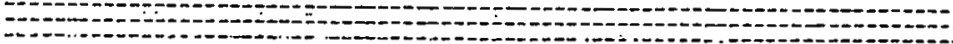
: 200

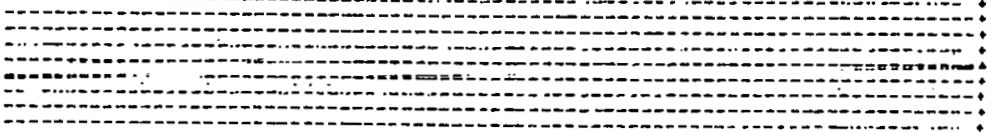

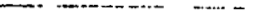

Figure 24b. First year of simulation of a temperate spring bloom. 

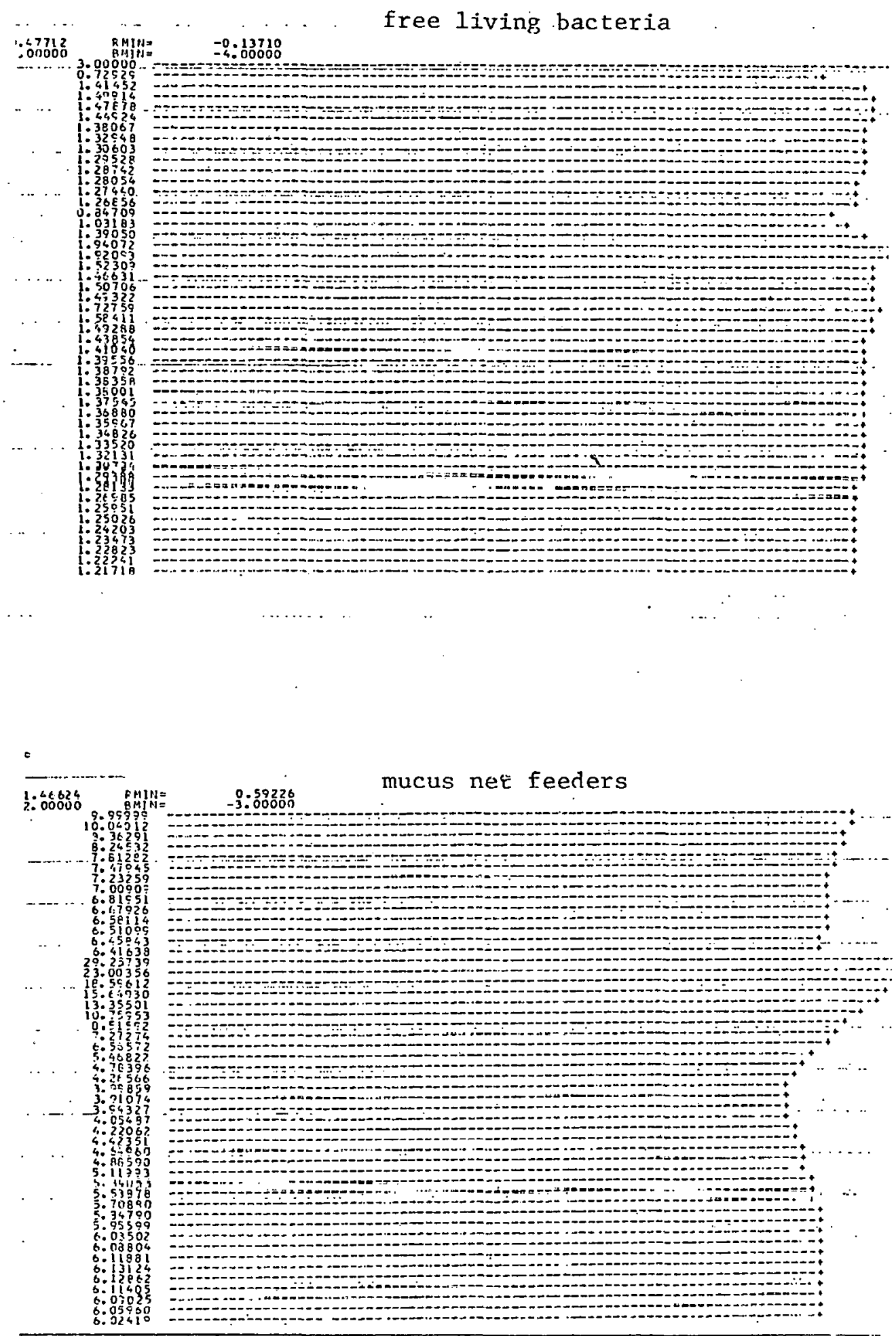

Figure 24c. First year of simulation of a temperate spring bloom. 

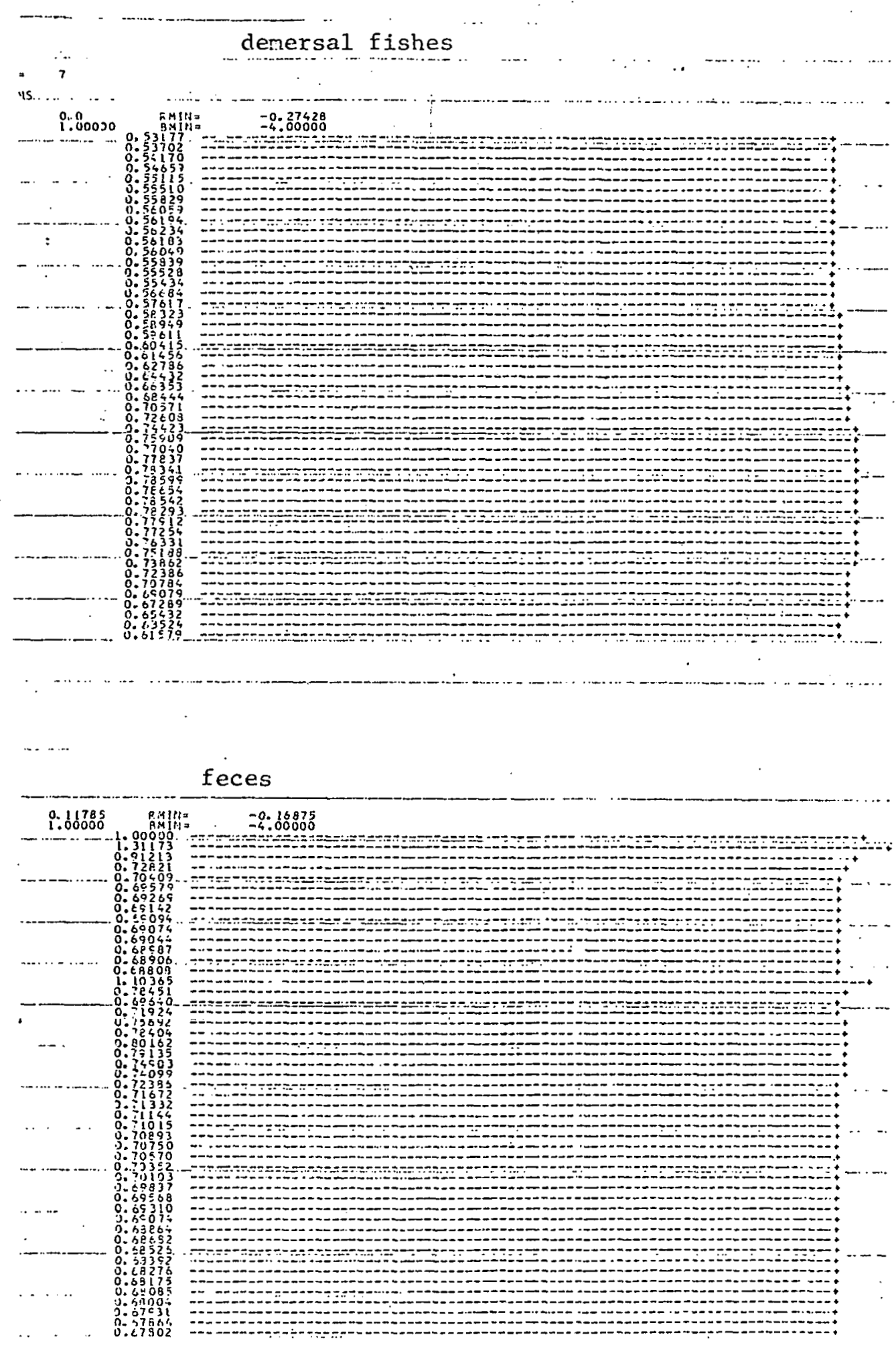

Figure 24d. First year of simulation of a temperate spring bloom. 

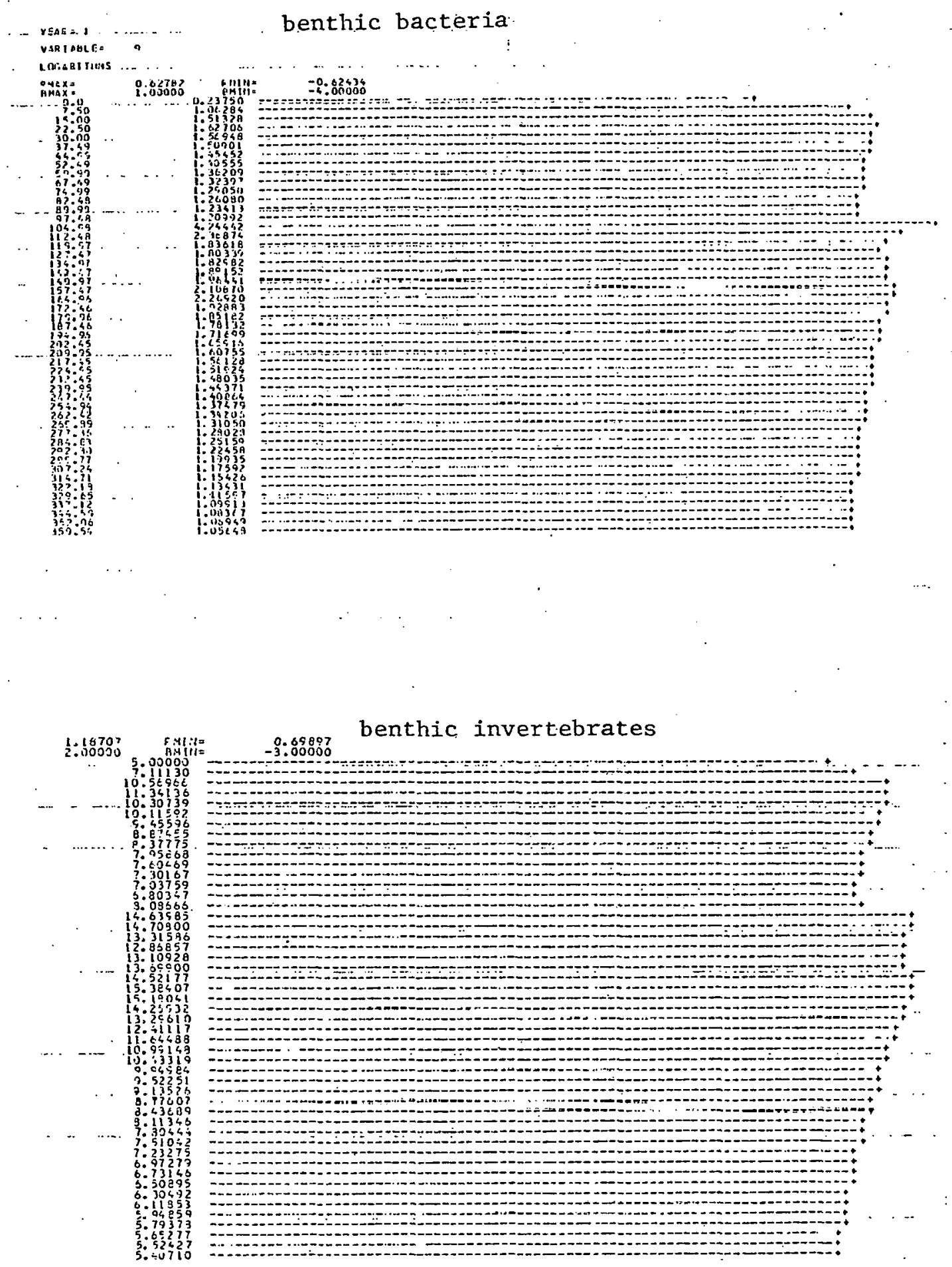

Figure 24e. First year of simulation of a temperate spring bloom. 
11
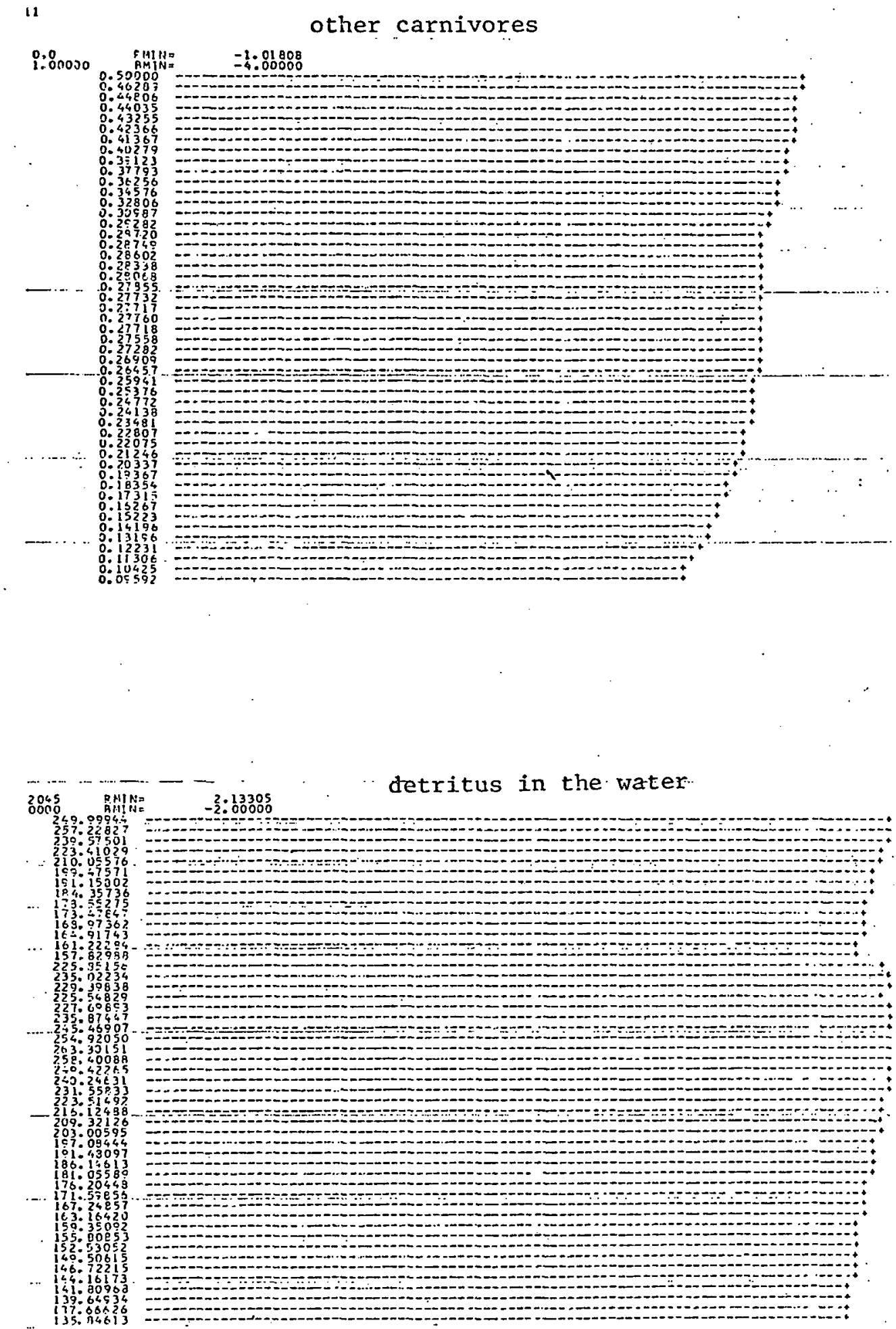

detritus in the water

Figure 24f. First year of simulation of a temperate spring bloom. 

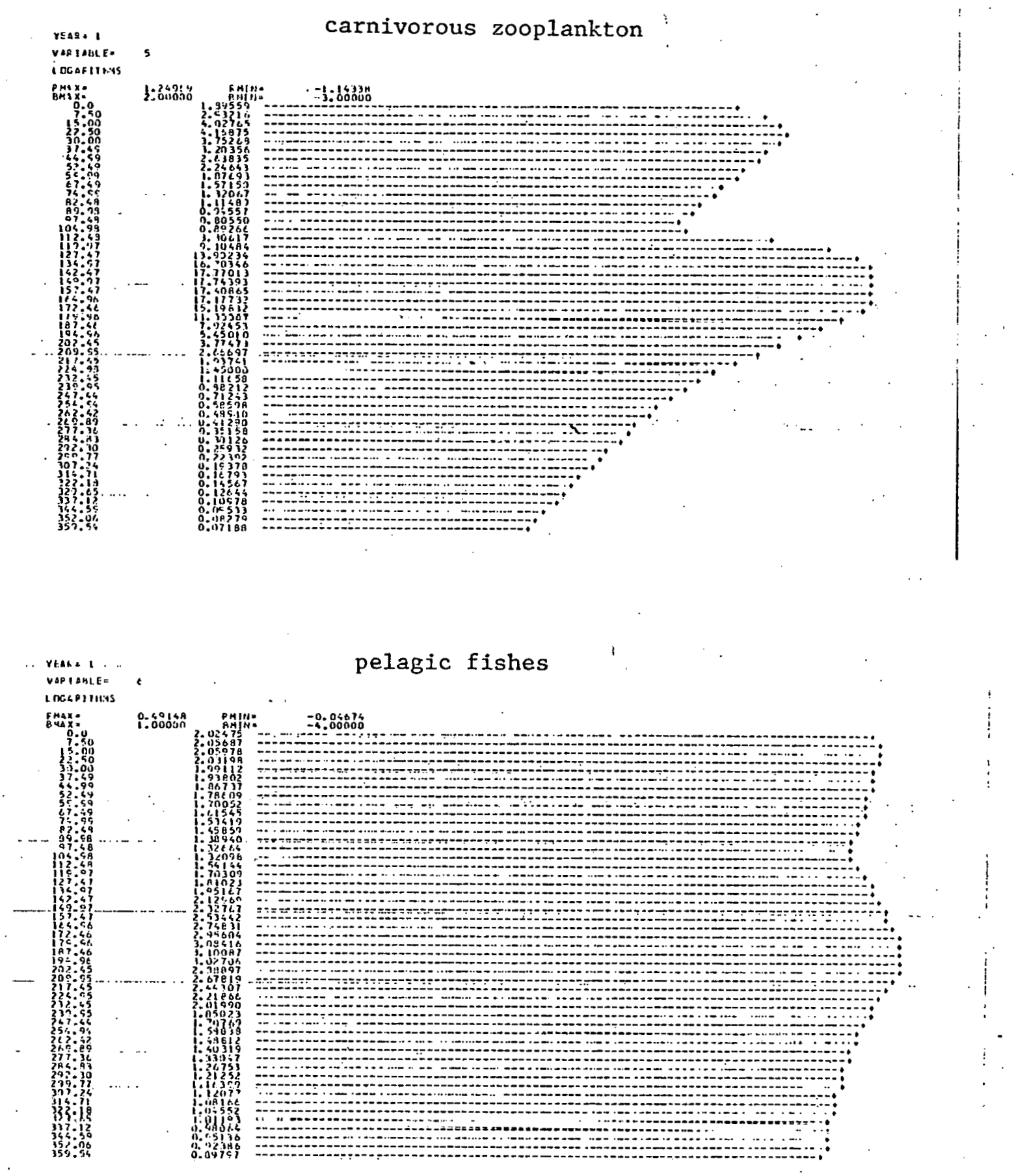

Figure 24g. First year of simulation of a temperate spring bloom. 


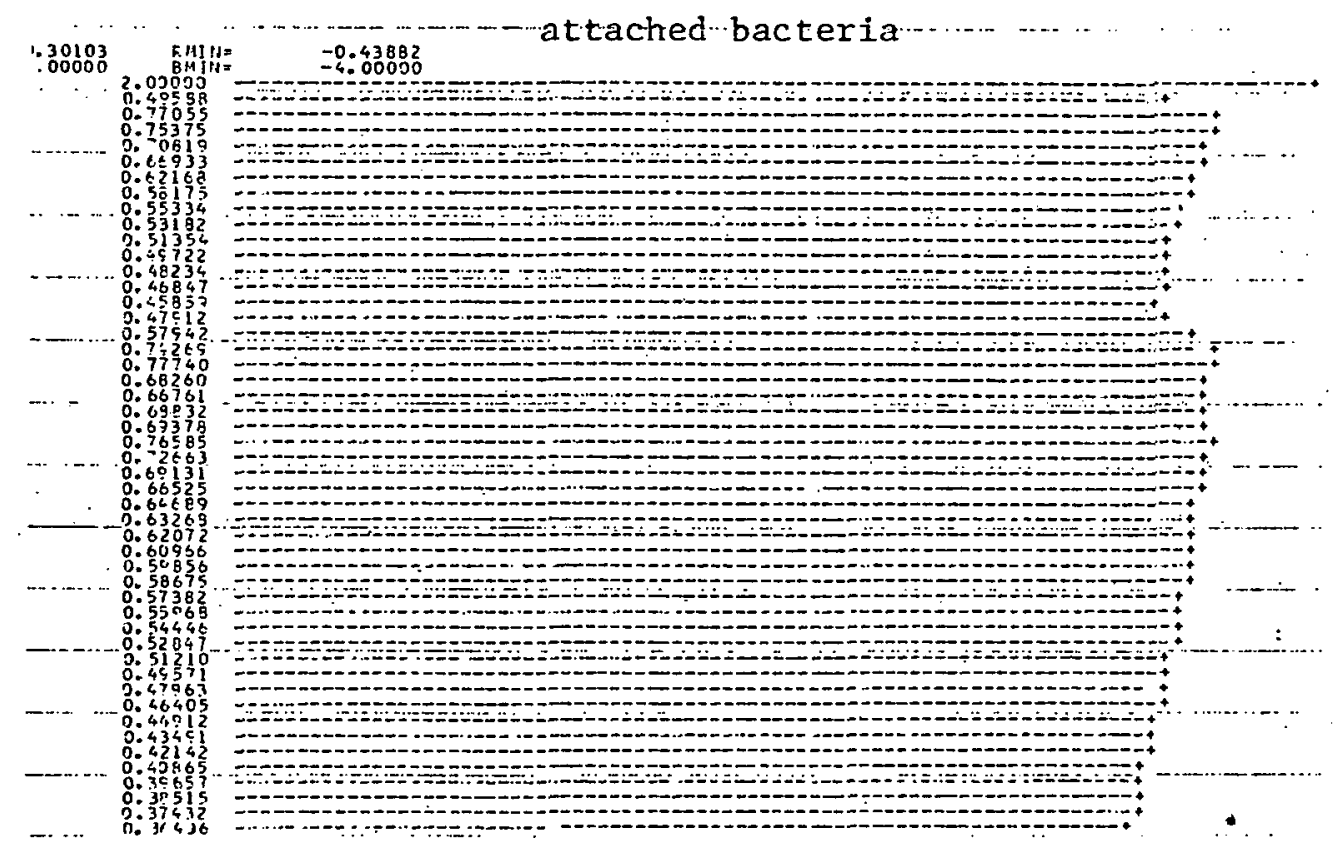

dissolved organic matter

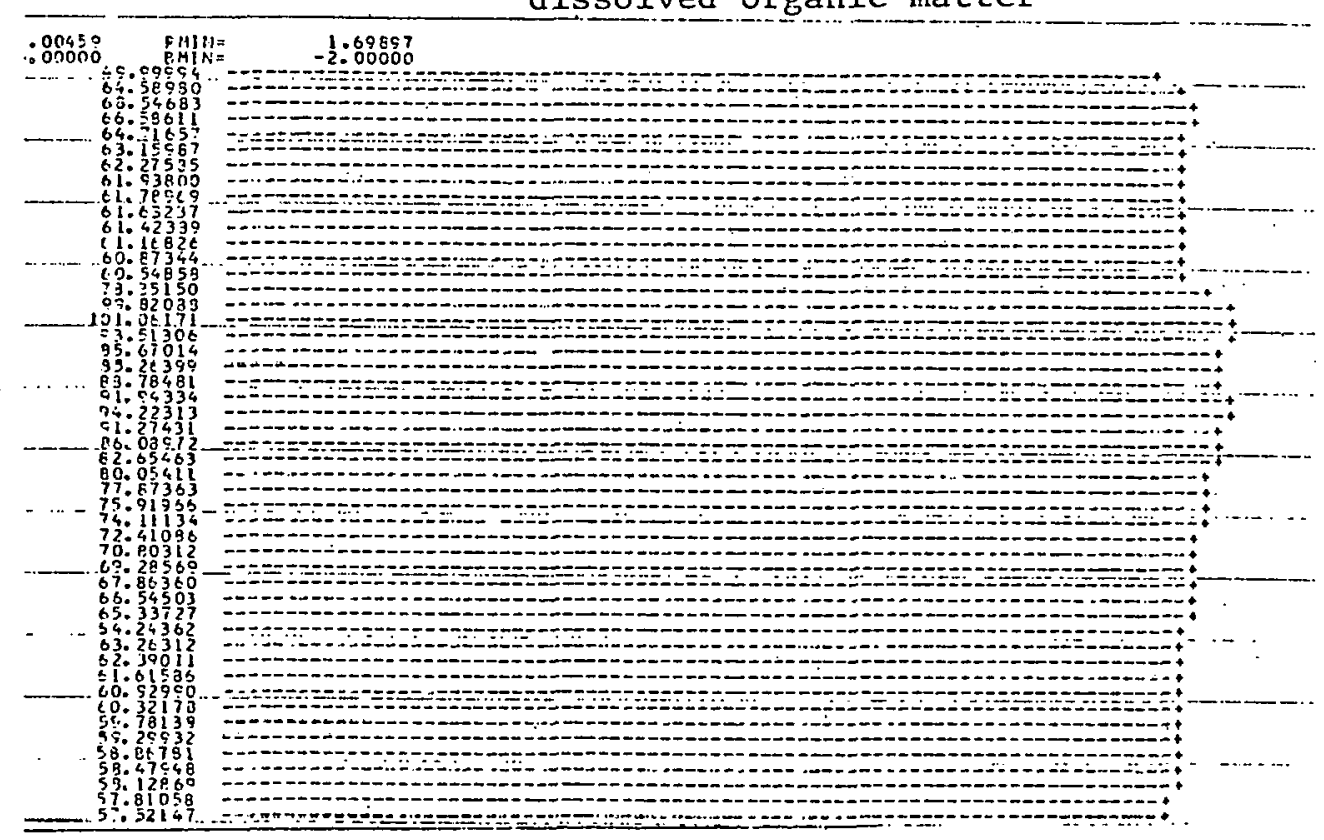

Figure 24h. First year of simulation of a temperate spring bloom. 

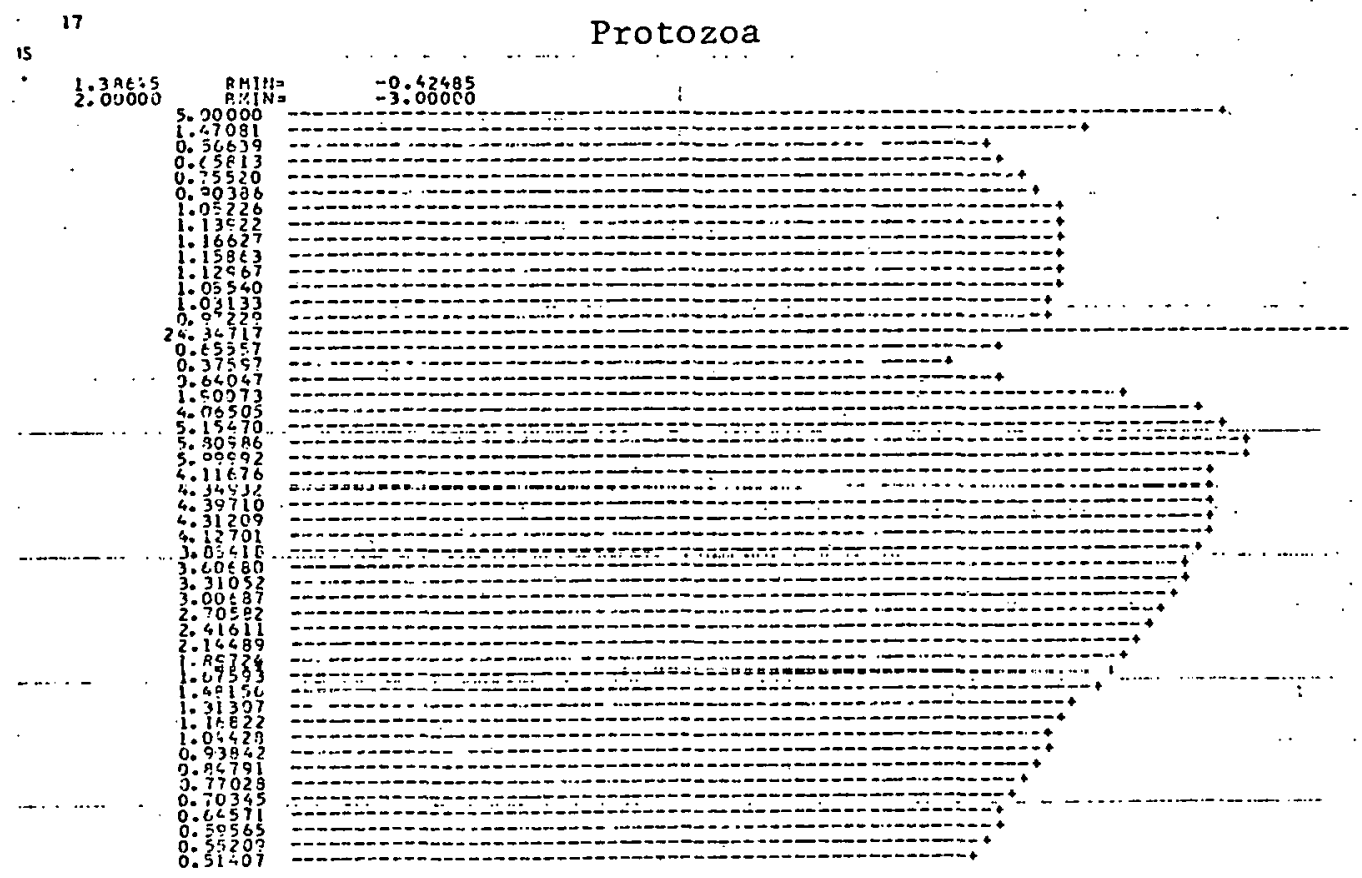

\section{Protozoa}

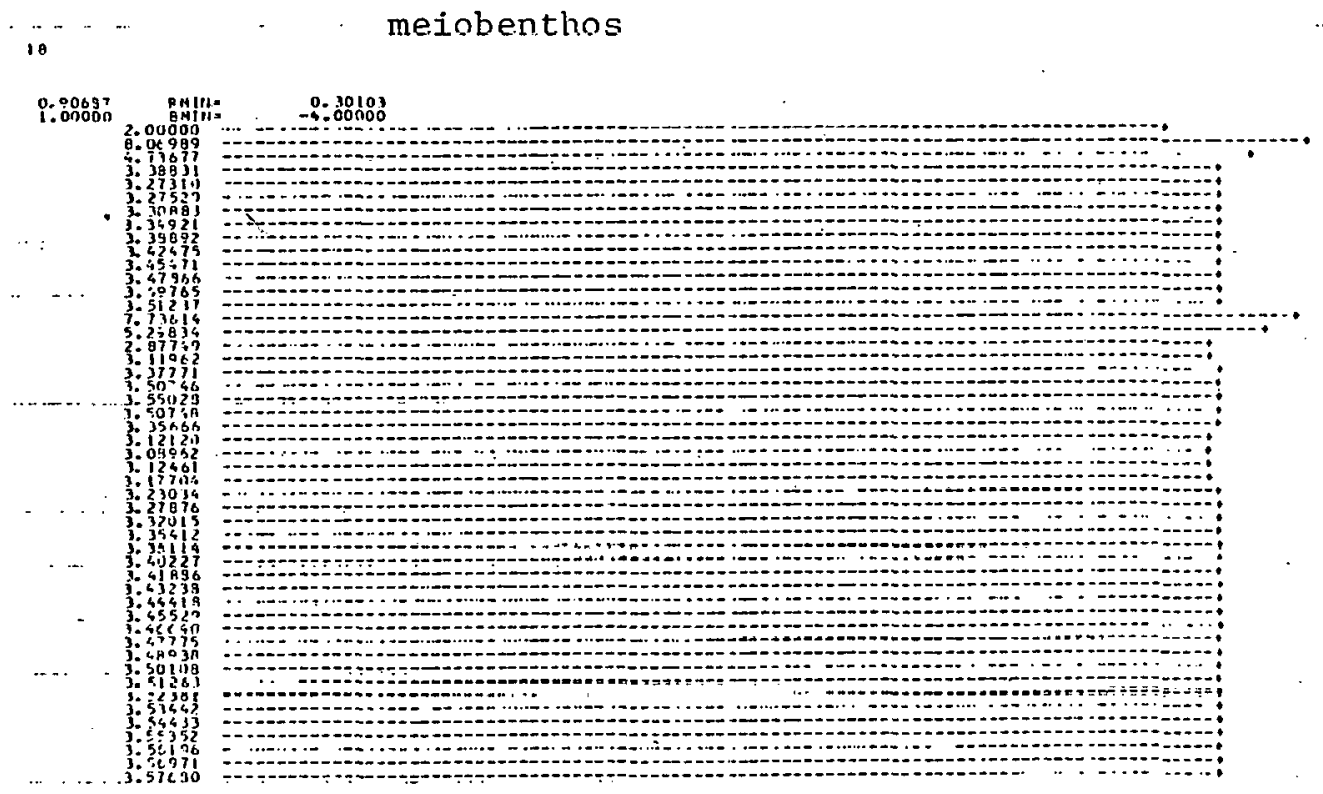

Figure 24i. First year of simulation of a temperate spring bloom. 
Because the first generation simulation model is space averaged, it would have limited value if coupled with more detailed physical models of intrustion phenomena. However, a two-layered model, which could easily be developed as a second generation, would not only add interesting biological details but could be meaningfully coupled to models or data sets of the physical regime of the southeastern continental shelf. The inherent strength of this kind of model is its basis in biological principles. It is not a curve-fitted model which simply reproduces in any convenient mathematical way the behavior of the ecosystem. Rather, the equations are developed as descriptions of biological function, just as good physical oceanographic models are descriptions of physical functions. The fact that the model produces realistic production values is therefore, a first-stage validation,

4. The Effect of Copper on Photosynthesis of Marine Phytoplankton

The interaction of naturally occurring dissolved organic matter. with heavy metals in solution in sea water may significantly modify the uptake of the metals by organisms. Therefore, analysis of total concentration of a metal in sea water does not permit inferences about its toxicity. A.M. Wood, who is now a Research Associate in the Biology Department of the University of Chicago, completed a doctoral dissertation on the effect of naturally occurring chelators on photosynthesis of naturally occurring phytoplankton populations while she was associated with this contract as a research assistant (Wood 1980).

To evaluate the effect of binding capacity of dissolved organic materials on copper toxicity it is necessary to measure binding capacity as well as copper toxicity. In collaboration with David Evans and James Alberts of the Savannah River Ecology Laboratory, Wood developed an ion-exchange method for measuring copper binding capacity in sea water. Toxicity was evaluated with a bioassay which consisted of $a \cdot{ }^{14} \mathrm{C}$ measurement of photosyhthetic carbon assimilation in the presence of known copper additions. This is the first time that a copper bioassay has been combined with a binding capacity measurement in a marine environment.

Binding capacity was highly correlated with total dissolved organic carbon concentration. Therefore, coastal waters and estuaries showed the highest binding capacities. At one station in Doboy Sound, Georgia, the binding capacity was so high that no copper toxicity could be demonstrated at 
$600 \mu \mathrm{g} \mathrm{Cu} 1^{-1}$. Other stations in Doboy Sound showed $50 \%$ inhibition at $\mathrm{Cu}$ concentrations greater than $100 \mu g 1^{-1}$. A series of samples from the Gulf of Mexico in the vicinity of Barataria Bay and the Mississippi River plume showed $50 \%$ inhibition of photosynthesis at $\mathrm{Cu}$ concentrations of $50-100 \mu \mathrm{g}^{-1}$. In contrast, Sargasso Sea samples showed $50 \%$ inhibition at $15-25 \mu \mathrm{g} 1^{-1}$.

These findings have implications for anthropogenic copper inputs into the ocean and continental shelves, such as those associated with the cooling systems of power plants. The binding capacity on the southeastern continental. shelf shows the full range of values, with very high capcity near shore to very low at the edge of the shelf. Release of equal amounts of copper on the inner and outer shelf would have very different biological consequences. The principle will apply to other heavy metals. Therefore this work should prove to be a benchmark in the bioassay of heavy metal toxicity in the ocean.

\section{Literature Cited}

Atkinson, L.P. 1977. Modes of Gulf Steam intrusion into the South Atlantic Bight shelf waters. Geophys. Res. Letters 7: 583-586.

Atkinson, L.P., G.-A. Paffenhöfer and W.M. Dunstan 1978. The chemical and biological effect of a. Gulf Stream intrusion off St. Augustine, Florida. Bull. Mar. Sci 28: 667-679.

Banse, K. and S. Mosher 1980. Adult body mass and annual production/bionass relationships of field populations. Ecol. Monogr. 50: 355-379.

Blanton, J. 0. 1979. Transport of freshwater off a multi-inlet coastline. Workshop on Wetland and Estuarine Processes and Water Quality Modeling. Baton Rouge, La.

Blanton, J.0. 1980. The transport of freshwater off a multi-inlet coastline. pp. 49-64 in: Hamilton, P. and K.B. MacDonald (Eds.) Estuarine and Wetland Processes. Plenum, New York.

Blanton, .T.n. and L.P. Atkinson 1978. Physical transfer processes between Georgia tidal inlets and nearshore waters. pp. 512-523 in: M.J. Wiley (Ed.), Estuarine Interactions. Academic Press; New York.

Blanton, J., L. Pietrafesa, L. Atkinson, and T.N. Lee 1979. Topographic induced upwelling in the South Atlantic Bight. Deep-Sea Res.

Campbell, W.B., T.R. Jacobsen, and L.R. Pomeroy 1979. Heterotrophic- photoautotrophic index: a qualitative parameter of microbial interactions applied to a Gulf Stream intrusion. Mar. Sci Communications 5: 383-398. 
Deibel, D. 1980. Feeding, growth, and swarm dynamics of neritic thaliaceans from the Georgia bight. Doctoral dissertation. University of Georgia. $150 \mathrm{pp}$.

Dunstan, W.M. and L.P. Atkinson 1977. Sources of new nitrogen for the South Atlantic Bight. pp. 69-78 in: M.L. Wiley (Ed.), Estuarine Processes, Vol. 1. Academic Press, New York.

Floodgate, G. D., G. E. Fogg, D. A. Jones, K. Lochte, and C. M. Turley. 1981. Microbiological and zooplankton activity at a front in Liverpool Bay. Nature (in press).

Fuhrman, J. and F. Azam. 1980. Bacterioplankton secondary production estimates for coastal waters of British Columbia, Antarctica, and California. Appl. Environ. Microbiol. 39:1085-1095.

Jacobsen, T. R. 1978. A quantitative method for the separation of chlorophylls a and b from phytoplankton pigments by high pressure liquid chromatography. Măr. Sci. Communications 4: 33-47.

Johnson, B. D. and R. C. Cooke. 1980. Organic particle and aggregate formation resulting from the dissolution of bubbles in sea water. Limnol. Oceanogr. 25: 653-661.

Johnson, P. W. and J. McN. Sieburth. 1979. Chroococcoid cyanobacteria in the sea: a ubiquitous and diverse phototrophic biomass. Limnol. Oceanogr. 24: $928-935$.

King, K. R., J. T. Hollibaugh, and F. Azam. 1980. Predator-prey interactions between a larvacean, Oikopleura dioica, and bacterioplankton in enclosed water columns. Mar. Biol.

Klinck, J."M., E. E. Hofmann, and G.-A. Paffenhöfer. 1981. Concentrations and vertical fluxes of fecal pellets on a continental shelf." J. Plankton Res. In Press.

Kranck, K. and T. Milligan. 1980. Macroflocs: Production of marine snow in the laboratory. Mar. Eco1. Prog. Ser. 3: 19-24.

Lee, T. N. and D. A. Brooks. 1979. Initial observations of current, temperature, and coastal sea level response to atmospheric and Gulf Stream forcing on the Geoogia shelf. Geophys. Res. Letters 6: 321-324.

Mills, E. L. 1980. The structure and dynamics of shelf and. slope ecosystems off the North East coast of North America. pp 25-47 in: Tenore, 'K.R: and B.C. Coull [Eds.] Marine Benthic Dynamics. Columbia, Univ: S. CaroLina Press.

Paffenhöfer, G.-A. and S.C. Knowles 1979. Ecological implications of fecal pellet size, production, and consumption. J. Mar. Res. 37:35-49.

Pietrafesa, L.J., J.O. Blanton, T.N. Lee, and L.P. Atkinson. 1981. The South Atlantic Bight, Physical and Biological description. In: R. Fournier [ed.] Shelf Break Processes on the East Coast of North America. Springer-Verlag Lecture Notes Series (in press). 
Pingree, D.M.; P.M. Holligan, and G.T. Mardell. 1979. Phytoplankton growth and cyclonic eddies. Nature. 278:245-247.

Pomeroy, L.R." 1979. Secondary production mechanisms of continental shelf communities. pp. 163-186 In: Livingston, R.G. [ed.] Ecological Processes in Coastal and Marine Systems. Plenum, New York.

Pomeroy, L.R. and D. Deibel. 1980. Aggregation of organic matter by pelagic tunicates. Limnol. Oceanogr. 25:643-652.

Riley, G.A. 1963. Organic aggregates in sea water and the dynamics of their. formation and utlization. Limnol. Oceanogr. 8:372-381.

Riley, G.A. 1970. Particulate organic matter in the sea. Adv. Mar. Biol. $8: 1-118$.

Savidge, G. and P. Foster. 1978. Phytoplankton biology of a thermal front in the Celtic Sea. Nature. 271:155-157.

Schindler, D.W., R.V. Schmidt and R.A. Reid. 1974. Acidification and bubbling as an alternative to filtration in determining phytoplankton production by the ${ }^{14} \mathrm{C}$ method. J. Fish. Res. Bd. Canada 29:1627-1631.

Smith, D.F. and W.J. Wiebe. 1976. Constant release of photosynthate from marine phytoplankton. Appl. Environ. Microbiol. 32:75-79.

Steele, J.H. 1974. The Structure of Marine Ecosystems. Cambridge, Harvard Univ. Press.

Tenore, K.R., C.F. Chamberlain, W.M., Dunstan; R.B. Hanson, B. Sherr, and J.H. Tietjen. 1978. Possible effects of Gulf Stream intrusions and coastal runoff on the benthos of the continental shelf of the Georgia bight. pp. 577-598. In: M.L. Wiley [ed.] Estuarine Interactions: Academic Press; New-York.

Waterbury, J.B., S.W. Watson, R.R.L. Guillard, and L.E. Brand. 1979. Widespread occurrence of a unicellular, marine, phytoplanktonic cyanobacterium. Nature. 277:293-294.

Watson, S.W., T.J. Novitsky, H.L. Quinby, and F.W. Valois. 1977. Determination of bacterial number and biomass in the marine environment. Appl. Environ. Microbiol. 33:940-946.

Wiebe, W.J. and L.R. Ponteruy. 19/2. Microorganteme aud hlieis association with aggregates and detritus in the sea: a microscopic study. Mem. Ist. Ital. Idrobiol. 29 Supp $1: 325-352$.

Wiebe, W. J. and D. Smith. 1977. Direct measurement of dissolved organic carbon release by phytoplankton and incorporation by microheterotrophs. Mar. Biol. 42:213-223.

Wiegert, R.G. 1975. Simulation models of ecosystems. Ann. Rev. Ecol. System. $6: 311-338$. 
Wiegert, R.G. 1979a. Modeling coastal, estuarine, and marsh ecosystems: State-of-the-art. pp. 319-341. In: G.P. Patil and M. Rosenzweig [eds.] Statistical Ecology, Vol. 12.

Wiegert,"R.G. 1979b. Population models: experimental tools for the analysis of ecosystems. In: D. Hain, G. Stairs, and R. MitchelI [eds.] Ecosystem Analysis. Columbus, Ohio State Univ.

Wiegert, R.G. and R.L. Wetzel. 1979. Simulation experiments with a fourteen-compartment model of a Spartina salt marsh. pp. 7-39. In: R.F. Dame [ed.] Marsh-Estuarine Systems Simulation. Columbia, Univ. S. Carolina.

Wiegert, R.G., R.R. Christian, J.L. Gallaher, J.R. Hall, R.D.H. Jones, and R.L. Wetzel. 1975. A preliminary ecosystem model of coastal Georgia Spartina marsh. pp. 583-601. In: L.E. Cronin [ed., Estuarine Research, New York, Academic Press.

Wood, A.M. 1980. Biological and chemical factors regulating the response of natural marine phytoplankton comminities to copper addition. Doctoral dissertation, Univ. of Georgia. $139 \mathrm{pp}$.

Zimmerman, R. 1977. Estimation of bacterial number and biomass by epifluorescence microscopy and scanning electron microscopy. pp. 103-120. In: G. Rheinheimer [Ed.] Microbial Ecology of a Brackish Water Environment. Heidelberg, Springer-Verlag. 


\section{Publications and Reports Resulting from this Contract}

A. Published

Jacobsen, T. R. 1978. A quantitative method for the separation of chlorophylls $\mathrm{a}$ and $\mathrm{b}$ from phytoplankton by high pressure liquid chromatography. Mar. Sci. Communications. 4: $33-37 .^{*}$

Pomeroy, L. R. 1979. Secondary production mechanisms of continentai shelf communities. pp. 162-186 in: R. E. Livingstone (Ed.) Ecological Processes in Coastal and Marine Ecosystems. Plenum Press, New York.*

Wood, A. M. 1979. Chlorophyll a:h ratios in marine planktonic algae. J. Phycology. 15: 330-332.

Wood, A. M. et al. 1978. Microbial Processes and biomass on the southeastern continental shelf. Cruise Report, 1975-1976. Georgia Marine Science Center Tech. Report. DOE Report No. SRO-0639-19.

Pomeroy, L. R. and D. Deibel. 1980. Aggregation of organic matter by pelagic tunicates. Limnol. Oceanogr. 25: 643-652.*

Pomeroy, L. R. 1980. Microbial effects of aquatic food webs. Microbiology- 80 . Amer. Soc. Microbiology, Washington. pp. 325-327.

Pomeroy, L. R. Microbial roles in aquatic food webs. In: R. R. Colvell and Joan Foster (Eds.). Aquatic Microbial Ecology. Univ. Maryland Sea Grant Publication UMSG-TS-80-03. pp. 85-109.*

Campbe11, W. B., T. R. Jacobsen, and L. R. Pomeroy, 1979. Heterotrophicphotoautotrophic index: a qualitative parameter of microbial interacions applied to a Gulf Stream intrusion. Mar. Sci. Communications. 5: 383398.*

Campbe11, W. B. 1981. Adenylate analysis in natural waters. Georgia Marine Science. Center Tech. Report. DOE report No. DOE/EV/UU639-21

B. Dissertations

Wood, A. M. Biulogical and Clemies1 Factors Regnlating the Response of Natural Marine Phytoplankton Communities to Copper Addition. University of Georgia . 139 pp.

C. In press

Hodson, R. E., A. E. Maccubbin and L. R. Pomeroy. Dissolved Adenosine triphosphate and its utilization by free-living and attached bacterioplankton. Marine Biology.* 
Jacobsen, T. R. Comparison of chlorophy11 a measurements by fluorometric, spectrophotometric, and high pressure liquid chromatographic methods in aquatic environments. Arch. Hydrobiologie, Beih. Ergebn. Limnol. In press.* *

D. : Manuscripts

Berman, T. Phosphorus uptake by microplankton in estuarine and coastal shelf water near Sapelo Island, Ga., U. S. A.*

Berman, T., R. B. Hanson, and W. J. Wiebe. Effects of organic substrate addition on size partitioning and respiration of 'single' versus clumped or 'attached' marine bacteria.*

Wood, A. M. and D. W. Evans Copper chelating capacity in the Sargasso Sea and on the continental shelf of the southeastern United States.*

*Publications marked with an asterisk are included as appendices to this report. 
THIS PAGE

\section{WAS INTENTIONALLY \\ LEFT BLANK}

